\title{
Pediatria e Saúde Mental da criança: uma experiência de ensino na Residência Médica
}

\author{
RAQUEL DIAZ DEGENSZAJN
}

Dissertação apresentada ao Programa de Pós-Graduação em Saúde Pública da Faculdade de Saúde Pública da Universidade de São Paulo para obtenção do título de Mestre em Saúde Pública. Área de concentração: Saúde MaternoInfantil

Orientador: Prof. Dr. Alberto Olavo Advincula Reis

São Paulo 2005 
Autorizo, exclusivamente para fins acadêmicos e científicos, a reprodução total ou parcial desta tese, por processos fotocopiadores.

Assinatura:

Data: 
Ao meu pai (in memorian) e à minha mãe, queridos, pela sustentação que me deram. Aos meus amados filhos Nathan e Rebeca por compreenderem o meu trabalho. Ao Jairo, companheiro adorado, pela solidariedade. 
Ao Prof. Dr. Alberto Olavo Advincula Reis, meu orientador, que com extremo senso de humor e refinada perspicácia, imprimiu a leveza necessária à condução deste trabalho.

À Prof. Dra. Augusta Thereza de Alvarenga e a Prof. Dra. Sandra Grisi pela leitura rigorosa e pelas excelentes sugestões fornecidas por ocasião do exame de qualificação e da Pré-Banca.

Aos colegas do Serviço de Psiquiatria e Psicologia do Instituto da Criança, em especial, à Vera, Deborah, Pilar, Annete, Teresa e Wagner, cujo respeito e consideração pelo meu trabalho permitiram a tranqüilidade para sua elaboração.

A todos os colegas da equipe de Pediatria do Centro de SaúdeEscola do Butantã, Prof. Samuel B. Pessoa, em especial, à psicóloga Maria Eugênia e aos médicos Viviane, Paulette, Cida, Renato, Marilene, Jaqueline, Sérgio, Fillumena, Maria Helena e Silmar, pela convivência calorosa e pela receptividade diante da minha iniciativa de empreender esta pesquisa.

Aos professores e funcionários do Departamento de Saúde Materno-Infantil da Faculdade de Saúde Pública da Universidade de São Paulo pela disponibilidade e cooperação.

A todos os residentes do Departamento de Pediatria da Faculdade de Medicina da Universidade de São Paulo, meus principais interlocutores nesta tarefa cotidiana de ensinar.

Às minhas queridas mãe, Aurita, sogra, Dália e irmãs, Iolanda e Monica, por toda a colaboração e apoio para que eu pudesse realizar este trabalho.

À Isabel, por me acolher e pela escuta atenta e precisa. 
"Mas já que se há de escrever, que ao menos não se esmaguem com as palavras, as entrelinhas." Clarice Lispector 


\section{RESUMO}

Degenszajn RD. Pediatria e Saúde Mental da Criança: uma experiência de ensino na Residência Médica. São Paulo; 2005. [Dissertação de Mestrado - Faculdade de Saúde Pública da Universidade de São Paulo].

O objetivo deste trabalho consiste na descrição e análise das avaliações realizadas por residentes da atividade de ensino "Saúde Mental da criança", ocorridas durante o estágio de Pediatria Comunitária no Centro de Saúde-Escola do Butantã, no primeiro ano de Residência Médica em Pediatria da Faculdade de Medicina da Universidade de São Paulo. Para contextualizar a experiência em questão, foi construído um percurso histórico a fim de delimitar a conformação das áreas da saúde da criança - Puericultura, Pediatria e Saúde Mental da criança - no campo da Saúde Pública. Problematizou-se a noção de subjetividade da criança como ponto central do trabalho desenvolvido com os residentes ao questionar sua importância para a formação do pediatra. A investigação foi realizada a partir de 58 textos produzidos pelos residentes no final do estágio, como avaliação. Os conteúdos foram trabalhados com base na análise de discurso. O trabalho de análise permitiu demonstrar a relevância da reflexão sobre o papel e a prática profissional e o despertar do interesse por um campo pouco explorado durante a graduação e a residência, que contribui significativamente para 0 atendimento integral da criança, preconizada pela instituição em foco.

Descritores: Ensino em Pediatria; Residência Médica em Pediatria; Saúde Mental da Criança; Subjetividade. 


\section{SUMMARY}

Degenszajn RD. Pediatrics and Children's Mental Health: an experiment on teaching at the Medical Internship. São Paulo (BR); 2005. [Master thesis - Faculdade de Saúde Pública da Universidade de São Paulo]

This paper describes and analyzes the internists' evaluation of the teaching programme on Children's Mental Health as part of the discipline of Community Pediatrics given at the Butantã Public Health Center during the first year of internship on Pediatrics at the Medical School of the São Paulo University. To give a proper context to the experiment, the author describes the historical process that helped to define the present situation of the disciplines involved with children's health - Puericulture, Pediatrics and Children's Mental Health inside the larger field of Public Health. The concept of the child's subjectivity is presented as the central point of the work with the internists and its'importance to their medical formation is discussed at length. This analysis is based on 58 texts written by the internists at the end of their period as part of their final exams. The texts' contents were studied by means of discourse analysis. This work demonstrates the relevance of the reflection about the professional role and practice and the growing interest on a field most unexplored through graduation and internship's years, with significant contributions to the global care of the children as postulated by the institute.

Descriptors: Pediatrics 'teaching; Pediatrics' Internship; Children's Mental Health; Subjectivity. 


\section{ÍNDICE}

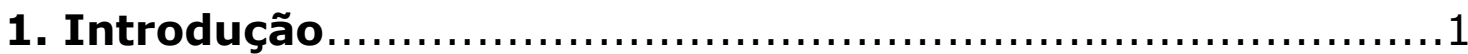

2. O surgimento da criança como objeto de atenção

na Saúde Pública ................................................. 10

2.1. Vidas desperdiçadas........................................... 12

2.2. Puericultura: a consagração do binômio mãe-criança........16

2.3. A Pediatria como especialidade médica........................19

2.4. A Saúde Pública e a Pediatria no Brasil.........................21

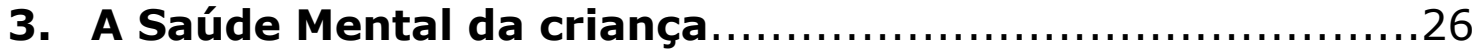

3.1. A Psiquiatria Infantil: histórico................................26

3.2. A Higiene Mental e a Saúde Mental da criança.................29

3.3. A Saúde Mental da criança no Brasil..........................32

4. Educação médica.................................................... 35

4.1. Histórico ..................................................... 35

4.2. O ensino médico no Brasil...................................40

4.3. A Residência Médica.........................................46

5. Uma experiência de ensino com residentes de Pediatria..51

5.1. O Departamento de Pediatria da Faculdade de Medicina da Universidade de São Paulo................................51

5.2. Do Serviço de Higiene Mental ao Serviço de Psiquiatria e Psicologia do Instituto da Criança............................54

5.3. Proposta de ensino: a subjetividade em questão...............59

6. Sobre o objetivo e a construção metodológica...............67

6.1. O objetivo....................................................67

6.2. As avaliações como discursos e os residentes como sujeitos da experiência.

6.3. A escolha do discurso do sujeito coletivo como estratégia metodológica de discursos-síntese................70 
6.4. Figuras metodológicas...................................... 72

6.5. Processo de construção dos discursos-síntese.................73

6.6. Aspectos éticos........................................... 74

7. Descrição e análise dos resultados.............................76

7.1. Caracterização dos discursos-síntese dos sujeitos produtores da avaliação............................................... 76

7.2. Sobre os significados e análise dos discursos-síntese......118

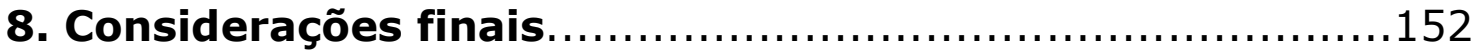

9. Referências................................................... 158

Anexos

Anexo 1 - Programa do curso de Saúde Mental da Criança

Anexo 2 - Termo de consentimento livre e esclarecido

Anexo 3 - Avaliações dos residentes 


\section{Introdução}

O interesse em elaborar esta dissertação de mestrado surgiu de uma série de indagações oriundas da experiência como psicóloga no Instituto da Criança do Hospital das Clínicas da Faculdade de Medicina da Universidade de São Paulo (I.Cr. - HCFMUSP). O I.Cr., vinculado ao Departamento de Pediatria da FMUSP, realiza assistência

à criança e ao adolescente, comprometido por um lado, com o ideário de atendimento global, portanto de caráter multidisciplinar e por outro - apoiado nos objetivos de ensino e pesquisa - visa cumprir seu papel na produção de conhecimento e formação profissional na área de saúde.

O tripé (assistência, ensino e pesquisa) no qual se sustenta esta instituição aponta para a necessidade de uma articulação constante entre esses diversos níveis, entendidos como indissociáveis.

Nosso propósito consiste em apresentar, descrever e discutir a atividade de ensino intitulada "Saúde Mental da criança", sob nossa responsabilidade, no contexto de treinamento médico em serviço de saúde durante o primeiro ano de Residência Médica em Pediatria na FMUSP, com base nas avaliações realizadas pelos residentes no término do estágio. Esta atividade compõe um dos estágios - 
Pediatria Comunitária - que é desenvolvido no Centro de SaúdeEscola do Butantã (CS-E), vinculado à FMUSP, cujo objetivo geral consiste em capacitar o residente a "reconhecer a importância da interação da criança e seu meio e sua repercussão no processo da relação médico-paciente, e a fazer o diagnóstico de saúde, propor ações e avaliar o impacto nas crianças da comunidade" (DINIZ e JACOB, 2001).

Portanto, no contexto de atividades próprias da atenção primária - que privilegiam a promoção e a prevenção em saúde - que ocorrem no CS-E, procuramos construir um espaço de aprendizagem e interlocução entre campos distintos. Nosso objetivo central nesta atividade de ensino refere-se à intenção de colaborar para o exercício de uma prática pediátrica que contemple a singularidade de cada caso e considere a importância das determinações sociais, econômicas, históricas mas, principalmente, as subjetivas.

Este desafio constante em nosso trabalho cotidiano parece-nos pertinente ao atual debate sobre a concepção de saúde mental, conforme o Relatório sobre Saúde no Mundo, publicado pela Organização Mundial de Saúde (OMS) e pela Organização PanAmericana da Saúde (OPAS), em 2001, que trata exclusivamente sobre o tema: "Saúde Mental: nova concepção, nova esperança". Convém ressaltar que o conceito de interdependência entre os mais diversos fatores que compõem a saúde mental - biológicos, sociais e psicológicos - sustenta uma nova posição frente ao tema, a despeito 
das dificuldades de defini-lo de uma forma completa. Conforme este Relatório (2001, p. 29), "os conceitos de saúde mental abrangem, entre outras coisas, o bem-estar subjetivo, a auto-eficácia percebida, a autonomia, a competência, a dependência intergeracional e a autorealização do potencial intelectual e emocional da pessoa".

Portanto, ressaltamos que a disposição em arquitetar este trabalho de dissertação fundamenta-se numa experiência construída ao longo de vários anos, mas que aponta para a necessidade de uma elaboração que contemple melhor nossas preocupações.

O discurso construído pela instituição baseia-se numa visão integral da criança, no entanto, este princípio se viabiliza na prática médica? Como se opera a construção desse conceito na formação do pediatra?

Notamos na prática pediátrica uma forte tendência à fragmentação e hierarquização dos diversos níveis que compõem a visão global da criança - que inclui aspectos biológicos, psíquicos e sociais. Isto se manifesta, em nosso entendimento, por um reducionismo da compreensão e abordagem dos problemas apresentados na clínica, com privilégio dos fatores biomédicos em detrimento do denominado psicossocial. Este estreitamento de campo freqüentemente é tema de debate e incômodo, vivido sobretudo pelos próprios médicos que o problematizam, atribuindo às falhas quanto a estruturação da formação básica, ao funcionamento dos serviços de 
saúde, às demandas da clientela ou mesmo à tarefa essencial do médico.

Interessa-nos aprofundar e ampliar esta problemática. Dentro do campo que escolhemos trabalhar nesta pesquisa, que é a formação médica, desenvolvemos nossa experiência norteada pela busca de estratégias que contemplem uma demanda constante, qual seja, a necessidade e importância de incluir os aspectos subjetivos que compõe a referida visão global. Conforme descreveremos adiante, o reconhecimento desta esfera, embora estabelecido como fundamental nos objetivos da formação do pediatra, sofreu uma série de transformações. Na instituição em que ocorre esta experiência, procuraremos pontuar os diversos níveis em que esta questão se explicita: na organização administrativa, na estruturação de serviços, na composição de disciplinas e práticas etc.

Entretanto, muitas questões se colocam: afinal, por que a subjetividade é importante no ensino da Pediatria? Qual o significado e quais as conseqüências de sua inserção? Se a pertinência deste âmbito parece indiscutível, como realizá-la sob forma de ensino e o que esperar, efetivamente, deste tipo de trabalho? É possível delimitar, com clareza, a validade desta forma de trabalho como algo significativo para a formação do pediatra? Finalmente, como o pediatra se coloca frente à subjetividade da criança e da família, como ele a compreende? 
Para o empreendimento desta análise, julgamos necessário explicitar o campo no qual situamos o objeto escolhido para contemplar nossos objetivos e para isto optamos, inicialmente, em circunscrever o recorte operado na Saúde Pública no que se refere à saúde da criança. Procuramos, primeiramente, localizar os determinantes históricos, políticos e ideológicos que contribuíram para a emergência da criança, como um objeto de atenção, cuidado e intervenção. Neste capítulo, procuraremos situar a inscrição da criança na rede social associada às profundas mudanças sóciohistóricas operadas a partir da Revolução Francesa e do processo de industrialização. Discutiremos as particularidades do movimento sanitário em torno da preocupação com a mortalidade infantil, consubstanciando as bases para a Puericultura e para a constituição da Pediatria como uma especialidade médica relativamente recente.

Sublinharemos a importância de diversos fatores na conformação deste campo de saúde da criança, que irão repercutir posteriormente. Em primeiro lugar, a difusão de conhecimentos de caráter científico e racional, promovidos pelos princípios da Puericultura que passaram a interferir no interior das famílias, caracterizando o movimento higienista. Outro ponto importante refere-se a constituição do corpo teórico e prático da Pediatria agregando os estudos sobre a Higiene Física e Mental às condições sócio-econômicas, ambientais e familiares da criança. Vale ressaltar o fato de que sua propagação ocorreu no âmbito de uma prática social 
adquirindo, posteriormente, seu lugar no interior das academias. E por último, interessa-nos destacar o caráter filantrópico como forma predominante de cuidado da criança até as primeiras décadas do século XX, marcando de forma inequívoca modelos de práticas em saúde, assumidas pelo Estado, de cunho assistencialista.

Em seguida, procuramos estabelecer semelhante percurso em relação ao campo da Saúde Mental da criança, assinalando, sobretudo, as dificuldades de se construir um espaço específico dentro da Psiquiatria. É notável a influência de outras disciplinas, a saber, a Psicanálise, a Educação, a Psicologia e a Neurologia que, por um lado, contribuíram para a importância da configuração da Psiquiatria Infantil, afirmando a especificidade da criança. No entanto, esta padece, até os nossos dias, da falta de uma estruturação teórica e institucional. O movimento higienista será retomado, pois, como veremos, sua importância articula-se às imposições relacionadas à educação física, moral, intelectual e sexual colocadas às famílias, com base nos preceitos sanitários da época, produzindo um conjunto de normas protagonizadas pela intervenção médica. Destacaremos, portanto, a Higiene Mental Infantil, seus princípios e métodos e a reconfiguração de conceitos que irão sustentar a substituição pela termo Saúde Mental, oferecendo recursos para pensarmos aspectos teóricos, relativos a esse campo.

No capítulo dedicado à Educação Médica, trabalharemos os marcos históricos que consolidaram as bases da atual Medicina: 
objetiva, científica e tecnológica. Procuraremos demonstrar como este projeto racional se configura no ensino médico em nosso país, revelando uma situação bastante problematizada, atualmente, quanto aos métodos de ensino, à proliferação desordenada de escolas médicas, com a conseqüente explosão do número de médicos e o preparo destes para o exercício profissional frente às particularidades da nossa realidade. Neste contexto, vamos abordar as questões ligadas à Residência Médica, como forma de aperfeiçoamento do trabalho médico, conhecido como treinamento em serviço, ressaltando a importância desta modalidade de ensino, na qual ocorre a experiência que pretendemos analisar.

Finalmente, apresentaremos um breve histórico do Departamento de Pediatria da FMUSP, do ideário contido na constituição do Serviço de Higiene Mental do Instituto da Criança (I.Cr) e seus deslocamentos, articulados às questões institucionais, para contextualizar a produção de nossa experiência de ensino. Procuraremos, então, apresentar a nossa proposta atual de trabalho com os residentes de Pediatria, no âmbito da atenção primária, realizado no Centro de Saúde-Escola do Butantã (CS-E), levantando as questões que procuraremos desenvolver neste trabalho.

Vale ressaltar nosso ponto de partida, que se explicita a partir do pressuposto de que 
a evidência científica moderna indica que os transtornos mentais e de comportamento resultam (....) da interação da biologia com fatores sociais (....) desde antes do nascimento e por toda a vida, os genes e o meio ambiente estão envolvidos numa série complexa de interações (....), cruciais para o desenvolvimento e a evolução dos transtornos mentais e comportamentais (OPAS/OMS 2001, p. 35),

Associamos esta concepção à importância prática de que a maior parte das demandas dirigidas ao pediatra nos serviços de saúde referem-se à doenças, cujos fatores de risco são bem conhecidos. No que tange aos problemas de Saúde Mental, temos estabelecido alguns conhecimentos que nos permitem intervir precocemente no curso e no desenvolvimento de quadros patológicos. Ora, o pediatra tem um papel único no acompanhamento do crescimento e do desenvolvimento da criança que permite ações de intervenção - no curso da sua constituição subjetiva - em fase precoce.

Nosso pressuposto é o de que o trabalho de ensino que realizamos no contexto do CS-E é pertinente aos princípios de promoção e prevenção em saúde, na medida em que privilegiamos o estudo e a reflexão de como se operam esses processos de subjetivação, contextualizados em nossa atualidade, conforme descreveremos adiante. Nossa preocupação aponta para a necessidade de detectar se esta atividade contribui para a formação 
de uma prática pediátrica integral, conforme preconizada pela instituição, na qual nos inserimos.

Considerando as conceituações em Psicanálise, no que tange especificamente à subjetividade, partimos da hipótese de que sua contraposição ao discurso científico - presente na formação médica e reiteradamente problematizada, como veremos - apresenta um instrumento importante para articular o singular, o particular e o geral no processo de assistência. Não se trata de estabelecer uma oposição entre objetividade e subjetividade, denunciando as diferenças, mas de buscar novos paradigmas que superem dicotomias, que apontam para um certo esvaziamento. Deste modo, procuramos atingir o objetivo da atividade de ensino que se refere à possibilidade de se construir uma prática pediátrica que articule as questões subjetivas da criança e da família aos problemas que são dirigidos ao médico.

Vale ressaltar a importância de buscar elementos teóricos que possam fundamentar uma articulação entre campos distintos de forma a criar novas modalidades de práticas, que privilegiem a reflexão e a busca de soluções através da interlocução entre disciplinas. Parece-nos, inclusive, pertinente "à reflexão acerca da Saúde Pública como campo de investigação interdisciplinar (....), cuja inserção como área de conhecimento não se circunscreve ao campo das ciências naturais, mas igualmente ao campo das ciências humanas" (ALVARENGA 1994; p. 23-4). Sublinhamos a característica 
multifacetada de seu objeto, de natureza biológica, social e psicológica, visto que se ocupa dos processos coletivos de saúdedoença, embora não tenhamos a pretensão de desenvolver o aspecto interdisciplinar, de forma mais aprofundada, neste trabalho.

A importância deste estudo parece-nos diretamente vinculada à possibilidade de contribuir para a produção de conhecimento na área de ensino em Pediatria. Consideramos o processo atravessado pelo Departamento de Pediatria da FMUSP que promoveu, no decorrer de 2000, uma série de fóruns com o objetivo de debater e avaliar o Programa de Residência com todos os segmentos envolvidos no ensino (residentes, docentes, médicos-assistentes etc) bastante significativo. Um novo Programa foi implementado no ano seguinte, passando a ser submetido à fóruns de avaliação gerais (duas vezes ao ano), alimentado pelas avaliações realizadas por cada grupo de residentes, em cada estágio. Nesse sentido, a discussão sobre os objetivos, procedimentos, dinâmicas dos diferentes serviços passaram a representar uma prática de intercâmbio permanente entre os que formam e os que estão em processo de formação.

De acordo com o Manual de Residência - Pediatria (DINIZ e JACOB 2001), a realização dos fóruns permitiu discutir "qual o tipo de médico pediatra que nosso departamento gostaria de formar" (p. 2), levantando algumas características desejáveis. Entre estas, assinalamos: "compreensão da criança como unidade biopsicossocial", "reconhecimento de que a ação do pediatra tem 
repercussões na vida da criança, sua família e comunidade" e "capacidade de trabalho multidisciplinar" (p.2), como ilustrativas da suposição da importância dos aspectos subjetivos, contidas nessas proposições. Logo, nosso estudo pode apontar não somente sua pertinência no contexto do ensino médico, mas evidenciar sua utilidade para a prática profissional, configurando uma contribuição de conhecimento aplicado (MARSHALL e ROSSMAN 1989, citado por ALVES-MAZZOTTI e GEWANDSZNAJDER 1998).

Para dar consistência à discussão que pretendemos empreender pareceu-nos oportuno analisar com mais profundidade a nossa experiência. Consideramos, então, necessário a utilização de um procedimento de análise do material composto pelos relatos escritos pelos residentes sobre esta atividade, ao final do estágio, como forma de avaliação. Desta maneira, pudemos estabelecer um contraponto entre o que se pretende alcançar e o que efetivamente pode ser formulado e elaborado, a partir da experiência do residente.

Para tanto, organizamos uma amostra representativa deste material, reunindo os relatos de 2003 e parte de 2004, totalizando 58 avaliações que foram submetidas à análise, utilizando abordagem qualitativa. Escolhemos como procedimento metodológico a construção do sujeito do discurso coletivo, de acordo com LEFÈVRE E LEFÈVRE (2003). Em seguida, ao tratamento destes dados, apresentamos os resultados, analisando-os. Consideramos, então, a partir de nossos achados que a atividade apresentou-se bastante 
produtiva, promovendo transformações significativas. A possibilidade de refletir sobre a prática e o papel profissional, a aprendizagem de novos conceitos, o despertar de interesse por um campo pouco explorado durante a graduação e a Residência e o contato com outros modos de interpretação de problemas enfrentados pelos pediatras foram os pontos mais destacados no nosso trabalho de análise.

Finalmente, no último capítulo, procuramos resgatar os questionamento que animaram a construção da nossa pesquisa para articular com os resultados obtidos, considerando a Educação Médica como nosso campo de conhecimento. 


\section{O surgimento da criança como objeto de atenção na Saúde}

\section{Pública}

Partindo do trabalho consagrado sobre a análise histórica e social das representações da infância, desenvolvido por ARIÈS (1981), propomos que a concepção sobre a criança emerge e se modifica de acordo com determinantes sociais, culturais, econômicos e políticos, característicos de cada período histórico.

Ao tomar a sociedade medieval como ponto de partida, ARIÈS (1981, p. 157) afirma que não existia "a consciência da particularidade infantil, (....) que distingue essencialmente a criança do adulto". A criança pequena, considerada frágil e sob risco de não sobreviver, devido ao alto índice de mortalidade nesse período, ficava restrita aos cuidados de sua mãe ou ama. Despertava certo encantamento e afeição por parte dos pais, porém tão logo adquirisse autonomia física e psíquica, misturava-se e confundia-se com os adultos.

Somente no século XVII é que surgiu o interesse psicológico e a preocupação moral com a criança, sobretudo entre os moralistas e educadores. À intenção em conhecer profundamente a criança somou-se o projeto educacional de torná-la um homem racional. A vida familiar sofreu um deslocamento para a escola - cujo principal instrumento utilizado foi a disciplina física e moral - que se constituiu graças à padronização do ensino, ocorrida no final do século XVII e início do século XVIII.

Um aspecto bastante destacado na análise que ARIÈS (1981) realiza refere-se à transformação que o processo educacional dirigido às crianças - acarretou à vida social. Sua hipótese é a de que o cuidado dispensado às crianças provocou uma alteração profunda na configuração do que conhecemos como a "família moderna". A 
escola passou a se constituir como o principal instrumento de preparação da criança para a vida entre os adultos e, na mesma medida, os pais incorporaram uma nova preocupação com a educação de seus filhos, dando consistência a uma "verdadeira moralização da sociedade" (ARIÈS, 1981, p.276). Houve, portanto, na constituição de ordens religiosas voltadas para o ensino uma eficiente disseminação de conceitos, nos quais os pais passaram a representar a responsabilidade pelo corpo e pela alma de seus filhos.

Cabe assinalar que a retirada da criança da sociedade, protagonizada pela família e pela escola, com a sistematização de mecanismos de controle, vigilância e punições, operou uma mudança profunda, qual seja: de um quadro da antiga indiferença para a atual obsessão pela infância.

É neste contexto que podemos situar a inscrição da criança na trama do tecido social, onde observamos um instigante fenômeno: a elevação da criança ao estatuto de um objeto privilegiado. Esta passou a se constituir como um foco de atenção, interesse e intervenção.

Agregado ao ideário disciplinador e normativo, representados pela educação, articulou-se um elemento novo, característico do século XVIII: a preocupação com a higiene e saúde física. De acordo com ROSEN (1994), o período que se estendeu entre meados do século XVIII e as primeiras décadas do século XIX "foram decisivos na evolução da Saúde Pública" (p. 113), no qual se construíram os alicerces do movimento sanitário, com desdobramentos inequívocos até os nossos dias.

A Europa vivia intensas mudanças, afetada pelas transformações políticas, sociais e econômicas, forjando as condições para o desenvolvimento do Iluminismo e da Revolução Industrial. É nesta época que observamos o surgimento de uma nova ordenação em termos de valores humanos, construída a partir dos ideais iluministas, cuja espinha dorsal sustentava-se na absoluta confiança 
do aperfeiçoamento humano através da educação e da disseminação do conhecimento.

Havia, portanto, um ambiente bastante favorável para a reflexão sobre os direitos do homem, suas condições de vida e a construção de um entendimento de que o processo saúde-doença encontrava-se articulado ao campo social. Logo, cresceu o interesse por problemas de saúde de grupos específicos.

\subsection{Vidas desperdiçadas}

De acordo com FOUCAULT (1986, p. 82), foi no século XVII que surgiram na Inglaterra e na França as estatísticas de natalidade e mortalidade e a preocupação em calcular a força ativa das populações, obedecendo a lógica mercantilista, no qual o aumento de produção, os grandes fluxos comerciais e a acumulação de riqueza promoveu o fortalecimento do Estado, apoiado na força do exército. Cabe assinalar, entretanto, que não se verificou, neste período, a organização de qualquer intervenção efetiva para melhorar o nível de saúde da população.

Destacou-se, principalmente na Alemanha, a sistematização de uma série de medidas, programadas e implementadas pelo governo, sob a alcunha de "polícia médica" entre o século XVIII e XIX. Graças a uma organização administrativa, foi possível controlar a atividade dos médicos que passaram a esquadrinhar a população, registrar nascimentos, óbitos, relacioná-los às doenças, promover regras de higiene etc. Estes conceitos se difundiram, posteriormente pelo restante da Europa e nos Estados Unidos.

A despeito de uma série de medidas que contribuíram para o surgimento de uma consciência sanitária e um aumento muito significativo da população, a taxa de mortalidade infantil, sobretudo entre os pobres, assustava as autoridades. De acordo com registros 
da época, em torno de 1750, a mortalidade infantil oscilava entre $80 \%$ e $90 \%$ em algumas localidades de Londres (ROSEN, 1994, p.118).

É oportuno destacar que tanto as precárias condições materiais de um certo segmento da população como o pouco valor dado às crianças constituíram fatores importantes para a compreensão da alta mortalidade, devido à prática corrente de abandonar os bebês em orfanatos. Calcula-se que "no último terço do século XVIII morriam, antes de um ano, mais de $90 \%$ das crianças abandonadas no asilo de Rouen, 84\% em Paris e 50\% em Marselha" (BADINTER, 1985, p.141)

Acrescenta-se, no século XVIII, um fenômeno que se generalizou, segundo BADINTER (1985, p. 67), que é a entrega de bebês recém-nascidos para amas-de-leite, verificado em todas as camadas sociais urbanas na França, que favorecia bastante a probabilidade de morte. A remuneração para esse cuidado era pequena, obrigando a cada nutriz aceitar vários bebês, levando, inclusive, ao abandono dos próprios filhos. Ainda, com esta autora, constatamos que de cada quatro crianças enviadas à amas, uma não completaria um ano de vida. "No conjunto da França, a taxa de mortalidade infantil era (...) de $27,5 \%$ de $1740-49$ e de $26,5 \%$ de 1780-89" (BADINTER, 1985, p. 138), considerando a grande variação de uma área para outra desse país, no qual pesam fatores como clima, salubridade e ambiente.

Esta tradução em números contribuiu, de forma importante, para a criação de um movimento de reforma, empenhado em buscar os fatores responsáveis por tão grave situação de mortalidade. Foi possível concluir, entre vários, a inadequação de cuidados com os bebês, a ausência de medidas higiênicas e de assistência médica frente aos agravos como diarréia, acidentes e infecções. O diferencial mais importante, que deve ser assinalado, relaciona-se à alimentação da criança: aquelas conservadas com a mães "morria duas vezes menos" (BADINTER, 1985, p.138) do que as confiadas às amas. É 
notável a intervenção do governo, que passou a fornecer assistência materna, incentivando o aleitamento natural que podem ser ilustrados pela criação do Dispensário para a Criança Pobre, na Inglaterra, em 1769 e posteriormente, pelo registro de campanhas maciças na França entre 1893-1903 (ROSEN, 1994, p.272-3).

Finalmente, outro fator que deve ser considerado e que se articula ao movimento da saúde refere-se às péssimas condições de trabalho nas primeiras fábricas, que empregava mulheres e crianças. Jornadas de trabalho longas e extenuantes, remuneração irrisória, acidentes recorrentes pela utilização de máquinas, insalubridade, ausência de descanso foram os elementos consagrados para a necessidade de regulação por parte do governo. O Ato da Saúde e da Moralidade dos Aprendizes, aprovado pelo parlamento inglês, em 1802 inaugurou essa preocupação por parte do Estado com o bemestar desses trabalhadores (ROSEN, 1994, p. 168). Esta medida proibia o trabalho noturno para os aprendizes pobres nas fábricas de algodão e pode ser considerada como uma extensão da Lei dos Pobres isabelina, de 1601 (que determinava o cuidado com o pobre como uma responsabilidade do poder público e privado). O movimento pela reforma das fábricas e a aplicação de medidas mais efetivas só ocorreu depois de décadas, privilegiando a proteção de mulheres e crianças, devido à alta incidência de incapacidade, doenças e morte diretamente ligadas ao trabalho.

Podemos observar, portanto, uma conjugação entre o amadurecimento que a sociedade foi tendo da importância da elevada mortalidade infantil à construção do conceito de "amor materno" e do valor do papel da mãe no cuidado da criança, que sofreu um mudança radical no final do século XVIII (MARQUES, 2000, p. 24). Esta autora assinala que "a criança adquire um valor mercantil, e ao mesmo tempo, o Estado e os filantropos voltam-se para as mães necessitadas" (p. 26), reforçando o significado de que cada bebê bem 
cuidado e com boa saúde representava o potencial de riqueza econômica para a sociedade no futuro.

Através dos progressos relacionados aos desenvolvimentos técnicos e científicos, um novo idealismo de cunho humanitário consubstanciou-se de forma extraordinária ao longo do século XVIII. Rapidamente assimilado por uma nova classe social representada pela burguesia, esta passou a combater as superstições e as idéias irracionais. Influenciada pela atmosfera otimista de que transformações sociais seriam alcançadas devido à ilustração do povo, uma nova mentalidade se engendrou, reservando à criança um lugar peculiar.

A filosofia política, as doutrinas morais, os interesses econômicos, as considerações comparativas sobre 0 desenvolvimento do gênero humano, as teorias médicas, a pedagogia, tudo o que tem a ver com o destino do homem, se fez ponto focal da teoria do conhecimento, e desta forma, necessariamente, conduziu para a realidade da criança. Esta interessou, na mesma medida, como objeto de compaixão humana, como tema científico e inclusive, como meta da razão do Estado com o que haveria de mudar, de modo acentuado, sua significação e sua posição. (SEIDLER, 1976, citado por MARQUES, 2000, p. 27).

\subsection{Puericultura: a consagração do binômio mãe-criança}

Conforme destacamos anteriormente, a criança adquiriu enorme visibilidade social e econômica a partir do século XVIII, devido às transformações históricas e políticas, produzidas pelos movimentos do Iluminismo e da Revolução Industrial. 
A radicalidade com que a sociedade atribuiu à família a responsabilidade de proteção à criança encontrou solo fértil na profunda mudança, agenciada pela burguesia, da consolidação da vida privada. Uma verdadeira "revolução das mentalidades" percorreu a transformação operada sobre o microcosmo social, que foi a família, baseada durante séculos na soberania divina do pai.

A "família moderna", submetida a uma afetividade nova fundada no amor romântico, "valoriza também a divisão do trabalho entre os esposos, fazendo ao mesmo tempo do filho um sujeito cuja educação sua nação é encarregada de assegurar" (ROUDINESCO, 2003, p. 19).

Como eixo condutor desta nova filosofia, é imprescindível atribuir a Rousseau a fundamentação e disseminação das idéias que deram consistência a importância atribuída à mãe para a proteção e conservação das crianças. Conforme apontado por MARQUES (2000, p.34), referindo-se a SEIDLER (1976), o tema do aleitamento materno, alçado à principal palavra de ordem na construção do discurso médico da época dirigido de forma privilegiada às mães, nada mais é do que a ressonância de Émile, de Rousseau, publicado em 1762.

Alguns passos podem ser marcados na lenta e progressiva construção dos cuidados com a criança de forma mais sistematizada. ROSEN (1994, p. 272) destaca a criação de um dispensário para crianças por um médico inglês, em 1816, que demonstrava o conhecimento das causas da mortalidade infantil e os meios adequados para combatê-la. Para tanto, foi necessário a instrução de mães e a organização de visitadores nos lares das famílias, que de forma prática e simples, "ensinavam" às mães como cuidar de seus filhos. Estes princípios, que já haviam sido aplicados por outros médicos anteriormente, representam "uma fase de transição no desenvolvimento da Higiene Infantil, moderna, e da Enfermagem de Saúde Pública" (p.272). 
Em 1860, Alfred Caron, médico francês, fundamentou um campo particular da higiene, voltada para a manutenção da saúde de bebês e crianças, através da publicação de Puericultura ou a ciência de criar os filhos de um modo higiênico e fisiológico. Décadas depois, ocorreu um progresso significativo no conhecimento da fisiopatologia da criança, contribuindo para a configuração de uma nova especialidade médica, a Pediatria, que teve início na França e na Alemanha, e pouco depois na Inglaterra e nos Estados Unidos (ROSEN, 1994, p. 273).

Registrou-se, neste período que se estendeu até as primeiras décadas do século $X X$, inúmeras iniciativas e programas dirigidos para esta fase da vida, com ênfase especial às iniciativas desenvolvidas na França, que serviu de modelo para outros países. Destacou-se o sistema inovador de clínicas de assistência à infância e a fundação de uma liga de combate à mortalidade infantil que, entre 1902 e 1907, multiplicou-se em 497 centros na França. A organização de um sistema de estações de leite, conhecido como Gouttes de lait (Gotas de leite), originária em Paris de 1890, permitindo a alimentação artificial de bebês que não podiam ser amamentados, irradiou-se definitivamente nas décadas posteriores (ROSEN, 1994, p.274).

Cabe lembrar que a modificação do leite de vaca, sua pasteurização (desenvolvida nos EUA e reproduzida nos demais países), a distribuição em mamadeiras esterilizadas, com as devidas orientações quanto à higiene e a preços acessíveis garantiram uma alimentação adequada e controlada dos bebês, elevando significativamente os indicadores de saúde. Essas estações difundiram-se na Inglaterra, a partir de 1901, na Escócia, dois anos depois, demonstrando a eficiência desta prática somada ao trabalho suplementar de visitadores sanitários para instruir as mães e a sistematização de consultas de bebês. Nota-se que a Alemanha também aderiu a estas práticas, fundando a primeira clínica com 
princípios semelhantes em Berlim, em 1905 (ROSEN, 1994, p. 274$5)$.

Estes empreendimentos adquiriram um valor histórico no contexto do movimento pela saúde da criança, pois revelam a importância de órgãos oficiais se responsabilizarem pela implementação e execução de tais programas, como o estabelecimento da uma Divisão de Higiene Infantil, no Departamento de Saúde da Cidade de Nova York, em 1908 (ROSEN, 1994, p. 275).

Neste momento, outro avanço extremamente significativo foi a peremptória necessidade de se articular programas de proteção à criança à saúde da mãe. A conexão entre o bem-estar maternal e infantil já havia sido estabelecida, em 1890, tanto por um obstetra francês, que criou o primeiro dispensário para mães, em Paris, como por um médico londrino que fundou instituição semelhante, em 1892. Entretanto, o primeiro programa de assistência pré-natal foi organizado em 1908, através do Departamento de Pediatria da Clínica Médica Ambulatorial de Nova York. Em 1915, na Inglaterra, registrou-se a criação de um centro pré-natal e a prática de visitas domiciliares feitas por enfermeiras, o que demonstrou a nova consciência de assistência e acompanhamento de mães e bebês como um instrumento altamente eficaz do controle de saúde da população e de prevenção de doenças, graças também ao avanços nos conhecimentos médicos (ROSEN, 1994, p. 279).

É relevante assinalar que o surgimento da Puericultura, como saber e prática, é considerado um marco decisivo para a formação do campo da saúde da criança, cuja principal característica pautava-se na disseminação de conhecimentos, oriundos do campo médico, portanto, de caráter científico e racional.

A mãe passou a ser o principal elemento transmissor desses novos conhecimentos e valores relativos não apenas à alimentação e higiene física, mas ao relacionamento interpessoal, garantindo a 
estabilidade da família, devido à transformação "em regras que definem a melhor forma de tratar uma criança" (NOVAES, 1979, p. 28). Neste sentido, conforme apontado por BOLTANSKY (1974), em seu clássico trabalho sobre o tema, o que marca a diferença da Puericultura com os demais projetos anteriormente empreendidos pelo saber médico pode ser traduzido por sua ambição civilizadora, cuja finalidade poderia ser sintetizada no combate aos costumes tradicionais, crendices, e preconceitos disseminados, sobretudo, nas classes populares.

Os pediatras, daquele momento em diante, puderam traçar uma linha de clivagem entre o que pertencia à medicina legítima e o que dela devia ser excluído. (....) O pensamento médico tornavase radical, polarizava: de um lado, a natureza e a tradição; do outro, a razão, a técnica, o comportamento moderno. (MARQUES, 2000, p.43)

\subsection{A Pediatria como especialidade médica}

Os serviços de Puericultura, sem dúvida alguma, foram os precursores de uma abordagem direta sobre a criança, contribuindo significativamente para o surgimento de uma nova especialidade médica, operando-se, assim, um corte, ao diferenciar definitivamente o adulto da criança.

É notável como a construção de um campo específico na área da saúde da criança resultou da confluência de inúmeros e decisivos fatores, já apontados. Destacamos, ainda, a noção de indivíduo e o entendimento da importância de intervir nas sucessivas fases do ciclo de sua vida agregados ao extraordinário avanço técnico-científico nas áreas de clínica, patologia, anatomia, bioquímica e fisiologia.

A questão da mortalidade e da morbidade por diarréias associada à alimentação forneceram o impulso necessário para a 
investigação e desenvolvimento das áreas de nutrição, higiene, metabologia, função digestiva. A combinação desses estudos com a noção de higiene física e mental e a inclusão de condições sócioeconômicas, ambientais e familiares como determinantes para a prevenção e tratamento de doenças constituíram o corpo teórico e prático, próprios à Pediatria (CARAFFA, 2001, p. 43). Sua consolidação se fez devido a criação de serviços, centros de assistência ou mesmo de clínicas, de caráter médico, social e de educação para a saúde, utilizando-se de instrumentos diversos oriundos de campos distintos.

A necessidade e a importância de se compreender a criança de um modo integrado, considerando fatores como ambiente, família e sociedade determinaram a especificidade da Pediatria como "uma disciplina que combina a prática da Clínica com uma doutrina maior de buscar a conservação das crianças" (CARAFFA, 2001, p. 44).

Quanto ao seu ensino, notamos que este se realizou primeiramente, nos hospitais e dispensários, tendo pouca penetração nas Universidades até o início do século $X X$, quando foram criadas as cátedras específicas. Ainda de acordo com CARAFFA (2001, p.44), "a Pediatria precisava, em primeiro lugar, demonstrar-se socialmente necessária, para depois se impor no interior das academias".

\subsection{A Saúde Pública e a Pediatria no Brasil}

Entre os médicos brasileiros que estudaram na Europa, nas últimas décadas do século XIX, destacou-se Moncorvo de Figueiredo, que teve contato com a Puericultura na França e que ministrou os primeiros cursos sobre doenças infantis na Policlínica Geral do Rio de Janeiro, fundada por ele em 1881. Este foi um marco importante no estabelecimento de uma prática médica ambulatorial, independente de um hospital e juntamente com a Maternidade de Laranjeiras, foram consideradas "as primeiras instituições médicas modernas 
fundadas no Rio de Janeiro" (NOVAES, 1979, p. 40). Data de 1882, a criação da Cadeira de Clínica Infantil na Faculdade de Medicina do Rio de Janeiro, proposta por Moncorvo de Figueiredo, nomeado o "pai da Pediatria Brasileira" (segundo AGUIAR, 1996 e TELLES, 1996, citado por CARAFFA, 2001).

Destacou-se, nas primeiras décadas do século $X X$, o aumento do número de creches, escolas, maternidades e publicações sobre a infância baseados nos princípios do discurso da Puericultura. Fatores históricos e políticos como a proclamação da República no Brasil e a urgência de um projeto de modernização social contribuíram para o crescimento do interesse em torno da criança.

É conveniente assinalar o caráter filantrópico como forma predominante de assistência à criança no período compreendido entre o século XVII até a década de 30 do século $X X$, imprimindo uma marca profunda em relação ao modelo de práticas pediátricas que se desenvolveram nas décadas posteriores em nosso país (MENDES, 1996).

As ações de saúde voltadas para a criança transformaram-se através da prática de consultas de Puericultura, distribuição de leite e programas de educação sanitária consubstanciadas em dispositivos como os centros de saúde (tendo como protagonista Geraldo de Paula Souza, em São Paulo, na defesa de uma estruturação sanitária básica), dispensários e serviços de assistência médica. Portanto, este conjunto de ações do Estado e da sociedade caracterizou-se, principalmente, por estar dirigido à pobreza e não como um direito à saúde da população.

Somente em 1940 foi criado um órgão federal - o Departamento Nacional da Criança (DNC) - que passou a ser incorporado ao Ministério da Saúde, em 1953. As pesquisas médicas e científicas articuladas às orientações técnicas dirigidas às instituições de saúde materno-infantil coordenadas pelo governo, sob influência da Sociedade Brasileira de Pediatria (SBP - fundada em 
1910) , garantiram um expressivo avanço no desenvolvimento da Pediatria no Brasil, até a década de 1960.

Devido ao golpe militar, ocorrido em 1964, observamos uma reconfiguração das relações entre Estado e sociedade. A criação do Instituto Nacional de Previdência Social, que ofertava benefícios a todos aqueles que trabalhavam com vínculo empregatício acarretou incentivos à prática médica individual, curativa e hospitalar, concentrando recursos para um determinado tipo de assistência e favorecendo a expansão da medicina empresarial. Como conseqüência, ocorreu uma diminuição de recursos destinados às políticas sociais e às práticas sanitárias, referenciadas nos princípios da saúde coletiva (OLIVEIRA e TEIXEIRA, 1989, citado por CARAFFA, 2001).

No que se refere ao cuidado da criança, ocorreu uma fratura importante representada pela decrescente influência dos pediatras da SBP no planejamento das ações de saúde, já que o DNC ficou reduzido à Divisão Materno-Infantil. Este distanciamento perdurou até o início da década de 1980.

A criação do Ministério da Previdência e Assistência Social e do Instituto Nacional de Assistência Médica e Previdência Social nos anos de 1970 foram uma tentativa de responder à exclusão de camadas sociais que não tinham acesso aos serviços, visando, através de várias estratégias, estender essa cobertura nas estruturas públicas estaduais e municipais de saúde, pois a crise econômica desencadeada nessa época, já repercutia de forma importante através dos índices relacionados à saúde da população.

Marcos históricos na cronologia de eventos relacionados à área de saúde tiveram amplo significado na constituição das políticas destinadas à assistência da criança, como a V Conferência Nacional da Saúde, em 1976 e a Conferência Internacional sobre os Cuidados Primários em Saúde, realizada em Alma Ata (antiga URSS), em 1978. Nota-se, claramente, a influência dos paradigmas propostos pela 
Medicina Preventiva e Comunitária que preconiza um modelo de atenção, organização e práticas de saúde que valorizam a promoção, prevenção e proteção à saúde, cujos cuidados primários e básicos encontra solo fértil e privilegiado na área materno-infantil, sobretudo pelo seu alcance e eficácia.

Com o fim da ditadura, registrou-se, na década de 1980, um amplo e trabalhoso processo de redemocratização em nosso país, multiplicado em inúmeros movimentos políticos dos mais diversos segmentos sociais. Os profissionais de saúde reagiram de forma organizada em torno de propostas baseadas na efetiva participação dos especialistas do setor, lançando os alicerces da conhecida Reforma Sanitária.

A realização da VIII Conferência Nacional de Saúde, em 1986 demonstrou a pujança de um movimento contido até então, cuja traço essencial pode ser sintetizado pelo caráter democrático, de participação e debate entre os setores da sociedade civil e de profissionais. A resultante deste processo traduziu-se na criação do Sistema Unificado e Descentralizado da Saúde (SUDS), em 1987, que avançou sobre o entendimento de três pontos fundamentais: "o conceito abrangente de saúde, a saúde como direito de cidadania e dever do Estado bem como a instituição de um Sistema Único de Saúde: com a defesa, pelo movimento da Reforma Sanitária, de uma reorientação dos modelos assistenciais para se alcançar o atendimento universal, de forma integral e eficiente socialmente" (CARAFFA, 2001, p. 56).

A Constituição, promulgada em 1988, legitimou os novos princípios que serviram como orientação para a criação de um Sistema Único de Saúde (SUS) e que preconiza, como estratégia, um corpo de preceitos organizativos para todo o país, nas três esferas de governo (federal, estadual e municipal), cuja estrutura de base se efetua graças à municipalização de serviços. 
É possível vislumbrar o valor atribuído ao projeto de uma assistência integral à criança, neste contexto, com a criação do Programa de Assistência Integral à Saúde da Criança (PAISC), em 1984, pelo Ministério da Saúde, voltado para crianças de até 5 anos, que propõe o acompanhamento do crescimento e desenvolvimento, 0 incentivo do aleitamento materno e o controle de doenças respiratórias, nutricionais e diarréias. Esta concepção de atenção à saúde repercutiu de forma relevante sobretudo na última década, na medida em que várias ações específicas passaram a ser incorporadas sob forma de estratégias de reforço à atenção básica, como o Programa de Agentes Comunitários de Saúde (PACS) e o Programa de Saúde de Família (PSF). Além de apresentarem um novo paradigma de modelo assistencial, estas práticas têm apontado a necessidade de um trabalho amplo e integrado (MARANHÃO, 2003).

Finalmente, o Estatuto da Criança e do Adolescente (ECA), consolidado como lei para todo o território nacional, a partir de 1990, fundamentou o compromisso do Estado com a assistência médica integral, dirigida à infância, através do SUS. Entretanto, vale afirmar que os indicadores atuais relativos à saúde da criança no Brasil sugerem claramente um enorme caminho a ser percorrido. E é neste contexto que a atividade apresentada como pesquisa neste trabalho se insere, ou seja, como colaboração dentro do processo de educação do futuro médico que poderá estar melhor instrumentalizado para o exercício de sua prática. 


\section{A Saúde Mental da criança}

De acordo com a análise que estamos construindo, no sentido de estabelecermos o recorte que foi realizado sobre a criança no campo da saúde, cabe destacar o percurso específico na área de Saúde Mental, pontuando suas origens, seus movimentos e tendências.

\subsection{A Psiquiatria Infantil: histórico}

"A psiquiatria infantil é uma especialidade recente" (Assumpção, 1994, p.4). Podemos considerar que suas raízes se encontram em algumas experiências pedagógicas desenvolvidas em séculos anteriores com deficientes mentais, auditivos e visuais, como por exemplo, o trabalho descrito por Itard, médico chefe do Instituto Imperial dos Surdos-Mudos de Paris, sobre uma criança de 12 anos, diagnosticada como "idiota" por Pinel, no final do século XVIII e início do século XIX (ITARD, 1967 e PESSOTTI, 1984, citado por ASSUMPÇÃO, 1994).

Durante o século XIX, configurou-se um entendimento de que não seria possível a existência da loucura na criança, crescendo, de forma importante, as experiências de caráter médico-pedagógicas dirigidas especificamente à deficiência mental. Nesse período, surgem diversos trabalhos "caracterizados pela tentativa de descrição de quadros paralelos ao retardo mental, baseados ainda em uma concepção adultomorfa dos problemas" (ASSUMPÇÃO, 1994, p. 4).

$O$ advento da psicanálise, no início do século $X X$, com a proposição do conceito do inconsciente e da sexualidade infantil, sobretudo o trabalho inaugural de FREUD, publicado em 1905, Tres 
ensaios para una teoria sexual, influenciou de forma contundente a clínica psiquiátrica da criança, que como veremos, virá a se configurar realmente a partir da década de 1930. (ASSUMPÇÃO, 1994; BERCHERIE, 2001; CIRINO, 2001).

$\mathrm{Na}$ tentativa de buscar as relações que se estabelecem entre a psiquiatria infantil e a psicanálise e como estas se inserem no campo da saúde mental infantil, CIRINO (2001, p. 66) retoma os pressupostos de KANNER (1971), AJURIAGUERRA (1980) e BERCHERIE (2001) para problematizar como este campo se compõe, qual é o seu objeto e como se constroem as propostas terapêuticas.

Inicialmente, cabe assinalar, que o saber psiquiátrico sobre a criança teve que, necessariamente, considerar aspectos muito diversos, tais como: os biológicos, somáticos, psíquicos, sociais e culturais, portanto, referidos a campos totalmente distintos do saber médico.

O estudo realizado por KANNER (1971), citado por CIRINO (2001, p. 68) sobre o esboço histórico do surgimento da psiquiatria infantil foi desenvolvido a partir da análise das quatro primeiras décadas do século $X X$, pontuadas por diversos acontecimentos e suas repercussões. Vale notar que este trabalho privilegiou as referências da literatura norte-americana, em detrimento de outros países, fato este apontado por Cirino (2001, p. 68) como significativo pela própria trajetória de Kanner. Formado em Medicina em Berlim, mudou-se para os EUA e, em 1930, Ihe foi confiado o serviço de Psiquiatria Infantil ligado ao Serviço Universitário de Pediatria do John Hopkins Hospital de Baltimore. KANNER ficou conhecido pela descrição realizada sobre o autismo infantil precoce, em 1943, tornando-se uma referência obrigatória sobre o tema.

Esta síntese parece-nos muito oportuna, pois destaca os movimentos mais importantes ocorridos na época, com amplas repercussões sobre os nossos dias. 
A marca mais importante da primeira década (1900-10) referiuse às "tendências culturais" relacionadas à abordagem psiquiátrica da criança, que podem ser vislumbradas através de várias vertentes que começariam a adquirir seus contornos mais nítidos nesse momento: a psicometria (avaliação da idade mental a partir do teste de desenvolvimento da inteligência, criado pelos franceses Binet e Simon); a abordagem psicodinâmica (influenciada pela psicanálise); a criação de tribunais de menores e, finalmente, o movimento da Higiene Mental. (CIRINO, 2001, p. 68).

Durante a segunda década (1910-20), proliferaram-se as instituições públicas dirigidas às crianças delinqüentes, abandonadas e com retardo mental. Na terceira década (1920-30), ocorreu a instalação de inúmeras Child-Guidance Clinics (clínicas de orientação infantil), fundamentadas numa proposta de atendimento multiprofissional (psiquiatras, psicólogos e assistentes sociais) destinados às crianças com distúrbios de conduta. A articulação destes profissionais com a família e a escola ofereceu uma compreensão entre os comportamentos das crianças e as atitudes dos adultos com as quais esta convivia, promovendo a busca de estratégias para lidar com os casos difíceis. Por fim, na última década (1930-40) analisada por KANNER, ocorreu uma sistematização de técnicas de psicoterapia, sobretudo através de brinquedos, devido à influência de Anna Freud - filha de Freud, que se dedicou à elaboração teórica e prática da abordagem de crianças (CIRINO, 2001, p.69).

De acordo com ASSUMPÇÃO (1994, p. 5), "daí em diante podemos observar duas vertentes na Psiquiatria da Infância, uma derivada de KANNER, com todas as influências ambientalistas, funcionalistas e de higiene mental; e outra, derivada da Psiquiatria Francesa, nosográfica e classificatória, definindo-se a si própria como organodinâmica e com a maior representação no Tratado de Psiquiatria Infantil, de AJURIAGUERRA". Os aportes teóricos da 
psicanálise ofereceram um amplo quadro teórico para o desenvolvimento da Psiquiatria de origem francesa, os quadros psicóticos, autísticos e sobretudo os quadros neuróticos (reativos e psicossomáticos) passaram a ser compreendidos à luz das teses desenvolvimentistas.

Na medida em que a Psiquiatria Infantil de origem anglo-saxã ganhou destaque, a partir da década de 1970, um novo movimento se engendrou na defesa da medicalização e na busca de relações entre os processos mentais e o funcionamento cerebral. A partir da Associação Americana de Psiquiatria, surgiu o DSM-III (Diagnostic and Statistical Manual of Mental Disorders), como uma forma ateórica de sistematizar as patologias mentais, orientado pela descrição do sintoma, descartando a compreensão do fenômeno apresentado (ASSUMPÇÃO, 1994, p.5).

A estruturação do campo da Psiquiatria Infantil poderia ser caracterizada, portanto, a partir de duas grandes tendências: uma visão biológica, "com preocupações nosológicas e etiológicas", por um lado, e por outro, uma visão que leva em conta a psicologia do desenvolvimento, as questões familiares e sociais e a educação (ASSUMPÇÃO, 1994, p.5).

\subsection{A Higiene Mental e a Saúde Mental da criança}

Conforme destacamos, os conceitos de educação em saúde e vigilância em saúde foram as ferramentas encontradas para evitar as doenças que dizimavam populações, portanto, diferentes estratégias foram desenvolvidas para evitá-las. O ensino dos cuidados com o bebê por profissionais preparados, no âmbito da Puericultura, parecenos um bom exemplo para demonstrar que, para além dos efeitos inquestionáveis de sobrevivência e conservação das crianças, esta 
prática constituiu-se como forma de controle, disciplina e ordenação da vida das famílias.

O movimento de Higiene Mental radicalmente associado aos progressos da Medicina, no início do século XX, fundamentou-se na mesma lógica preventiva, na qual medidas profiláticas impediriam o desenrolar de processos patológicos. A idéia de que a insanidade e a delinqüência poderiam ser evitadas baseou-se em um novo ideário, firmado na época pela concepção de que os primeiros indícios seriam observáveis na infância do indivíduo. Para tanto, justificou-se a importância dada à observação mais acurada dos comportamentos infantis que pudessem sugerir ou revelar uma patologia na esfera psíquica.

O que se pretendia atingir com a prática higienista era justamente $o$ indivíduo saudável, tendo como auxiliar a higiene corporal e a higiene pública. Este saber higienista articulou-se também à concepção de eugenia, entendida como um conjunto de intervenções que pudessem melhorar a bagagem genética de alguns seres vivos. Para tanto, defendeu-se medidas radicais como a eliminação de indivíduos (biologicamente inferiores), esterilização e incentivo à reprodução entre indivíduos considerados biologicamente superiores (CIRINO, 2001, p. 71).

No final da década de 1940, o termo higiene foi substituído por saúde, já que o primeiro ficou identificado com os pressupostos eugênicos. Um ponto de inflexão importante ocorreu neste momento, em que se procurou promover a Saúde Mental a partir de uma perspectiva centrada na saúde, buscando causas e maneiras de harmonizar indivíduo e ambiente. A Sociologia e Psicologia comportamental forneceram o suporte necessário à criação da concepção de indivíduo como unidade biopsicossocial, que funcionou como um alicerce para as práticas de saúde realizadas por equipes multiprofissionais. Cada profissional (médico, psicólogo, assistente 
social etc) oferecia o seu saber específico, fragmentando o indivíduo para depois compô-lo novamente, como um mosaico.

Cumpre notar que a terminologia Saúde Mental ofereceu múltiplas interpretações. Pode descrever "um estado de bem-estar positivo (...) até um movimento nacional e internacional relacionado com pesquisa, prevenção e tratamento do mentalmente doente" (LEAVELL e CLARK 1976, p. 420). Ela pode significar uma reação à hegemonia do saber médico, representado pela Psiquiatria tradicional. Pode ser compreendida como um conjunto de teorias e práticas terapêuticas vinculadas à Psiquiatria e à Psicanálise, tendo como questão central "a problemática do sujeito nas suas articulações com o social" (BIRMAN e BEZERRA, 1994, citado por CIRINO, 2001, p. 75). Ou até mesmo como "o campo efetivo das diferenças com respeito às normas sociais" (LAURENT, 1999, citado por CIRINO, 2001, p. 75).

Enfim, "o termo refere-se também à especialidade da Saúde Pública que trata do processo de redução da quantidade de perturbação mental numa comunidade e do estudo da quantidade e dos tipos de doença mental e os fatores psicológicos, físicos e sociais que são de significância etiológica" (LEAVELL e CLARK 1976, p. 420).

Entretanto, no que concerne à criança, temos a noção da importância da disseminação de conhecimentos sobre o seu funcionamento mental, dispostos aos interessados de acordo com as mais diversas teorias construídas sobre disciplinas diferentes: Pediatria, Psicologia, Pedagogia, Neurologia, Psiquiatria, exercidas nas mais diversas instituições: escolas, hospitais, varas de infância. $O$ efeito deste movimento, sem dúvida, é o de segmentação em grupos de crianças, a partir de alguns fenômenos (criança abandonada, criança hiperativa, com dificuldade de aprendizagem etc) que dão uma certa homogeneidade a partir de fenômenos comuns, desconsiderando a singularidade de cada caso. 
$\mathrm{Na}$ história mais recente deste movimento, vale ressaltar a tentativa de superação do paradigma asilar, fortemente influenciado pela experiência italiana, cujo expoente foi Franco Basaglia e que no Brasil recebeu o nome de Centros ou Núcleos de Atenção Psicossocial (CAPS ou NAPS). A proposta de desinstitucionalização do paciente psiquiátrico proliferou-se de várias formas, buscando meios democráticos nas relações institucionais, denunciando práticas de violência e, sobretudo, estabelecendo uma nova noção de cuidado dirigido ao indivíduo psiquicamente adoecido, desvinculando-se do objetivo de remissão de sintomas. O termo psicossocial aponta para a necessidade de trabalhar as duas dimensões de maneira articulada, "a dimensão psíquica envolveria a questão da subjetividade e da criatividade, enquanto a dimensão social conceberia a família ou o trabalho de forma menos excludente" (CIRINO, 2001, p. 77).

\subsection{A Saúde Mental da criança no Brasil}

De acordo com ASSUMPÇÃO (2003, p. 3-4), a origem da Psiquiatria brasileira deve-se a um movimento de protesto da Sociedade de Medicina contra as precárias condições de assistência aos doentes mentais nos Hospitais das Santas Casas de Misericórdia, em meados do século XIX. A prática médica dirigida aos doentes mentais, nessa época, baseava-se no controle disciplinar do indivíduo associado à questão moral, desprovido de um caráter científico.

Em 1900, um trabalho chamou a atenção no IV Congresso de Medicina e Cirurgia, intitulado $O$ tratamento dos idiotas e, em 1917, o caso de uma criança de 12 anos - que apresentava um quadro delirante alucinatório e que havia cometido um crime - foi apresentado em sessão da Sociedade Brasileira de Neurologia, Psiquiatria e Medicina Legal no Rio de Janeiro. O primeiro serviço de menores foi criado no Hospital do Juqueri em São Paulo, em 1921. 
Nesse momento, havia a influência das escolas francesa e alemã de Psiquiatria, baseadas numa perspectiva biológica e causal, bem como a ocorrência de estudos sobre hereditariedade, eugenia e o modelo higiênico, de cunho disciplinador e de controle social e moral (ASSUMPÇÃO, 1994, p. 6).

A relação entre a Psiquiatria Infantil e a deficiência mental, conforme apontado anteriormente, pôde ser constatada em 1927, em Minas Gerais, pela aprovação de decreto que regulamentou a assistência e proteção de menores abandonados e delinqüentes e que garantia assistência aos anormais (por déficit físico, sensorial, intelectual e das faculdades afetivas). Fato significativo também pode ser atribuído à fundação do Instituto Pestalozzi destinado ao atendimento de toda criança com suspeita de deficiência ou perturbação mental, na década de 1930, em Belo Horizonte (ASSUMPÇÃO, 1994, p. 6).

Conforme ASSUMPÇÃO, seriam delineadas duas vertentes na construção do campo da Psiquiatria Infantil no Brasil, a primeira vinculada à Psiquiatria clássica, em que impera uma visão biológica e moral, de caráter asilar, e, a segunda, inspirada na concepção psicodinâmica e social, desenvolvidas nos Departamentos de Pediatria.

Durante a década de 1940, Stanislau Krinsky, que trazia sua experiência na direção do serviço de menores do Hospital do Juqueri vinculou-se ao Departamento de Pediatria da Faculdade de Medicina da Universidade de São Paulo (FMUSP), coordenado pelo Prof. Pedro de Alcântara. Em 1955, foi criado o Serviço de Higiene Mental baseado no Child- Guidance Clinics, que será apresentado como um dos temas de nossa pesquisa e desenvolvido posteriormente.

Em 1965, foi fundada a Associação Brasileira de Deficiência Mental (ABDM) e em 1967, foi criada a Associação Brasileira de Neuropsiquiatria Infantil (ABENEPI), ambas presididas por S. Krinsky. A neuropediatria se organizou por todo o país, a partir do trabalho do 
Prof. Antonio B. Lefèvre, arregimentando muitos seguidores. No entanto, a Psiquiatria Infantil teve grandes dificuldades para constituir um corpo teórico específico, vindo a se constituir como disciplina do Departamento de Psiquiatria da FMUSP, em 1975, sendo reconhecida como especialidade em 1988.

Finalmente, de acordo com ASSUMPÇÃO (1994, p. 8), a expansão do trabalho clínico com crianças adquiriu amplo espaço entre os psicanalistas, com um modelo de atendimento individual. Por outra parte, a Neuropediatria passou a se ocupar de temas tradicionalmente de competência da Psiquiatria, "que fica assim comprimida entre duas áreas mais organizadas e com maior estruturação teórica e institucional". Embora com experiências notáveis, como a Comunidade Terapêutica "Enfance", dirigida por Oswaldo Di Loretto, nas décadas de 1970-80, ou mesmo a criação de Hospital-Dia Infantil, pela prefeitura de São Paulo, na década de 1980, vemos multiplicarem-se experiências inovadoras e criativas no atendimento da criança com grave sofrimento psíquico, sob forma de ONGs ou vinculadas à Universidades. Entretanto, são movimentos descontínuos, pontuais e que tendem a naufragar, pois carecem de uma sustentação maior, representado pelo poder público. 


\section{Educação Médica}

Para articularmos as questões apresentadas a partir do recorte operado sobre a saúde da criança, cumpre realizar um desenvolvimento sobre o ensino médico, já que nossa experiência encontra-se inserida em serviço universitário de saúde. Esta contextualização parece-nos fundamental para compreendermos nossa inserção e analisarmos o alcance de nossas propostas.

\subsection{Histórico}

Até a Idade Média, a prática e o ensino em Medicina poderiam ser traduzidos como uma síntese entre empirismo, observação e superstição. A partir da Revolução Francesa, desencadeou-se um processo importante que contribuiria para uma reforma no ensino médico, devido sobretudo ao estudo do paciente e da realização de autópsias. Vemos, aqui, lançadas, de modo irreversível, as bases da investigação objetiva e técnica, de cárater eminentemente racional. Paris foi considerado o centro irradiador do ensino médico mundial por mais de um século (LEMLE, 1989).

Durante o século XIX, a escola alemã e austríaca avançaram de maneira expressiva graças à criação, pelos reis da Prússia, de inúmeros institutos de pesquisa em ciências médicas - principalmente nas áreas básicas. A partir de farto material clínico e pelo alto nível de treinamento objetivo, notamos a presença dos elementos essenciais para a pesquisa científica que passou a permear as ações médicas, constituindo-se como base da atenção médica, tornando, assim, inseparáveis a pesquisa da prática. Outro importante marco neste processo histórico ocorreu no final do século XIX na Inglaterra: Oxford e Cambridge tornaram-se centros importantes de excelência na prática e no ensino médico, baseados na institucionalização do 
internato, ao organizarem de forma sistemática uma modalidade praticada desde a Idade Média, conhecida como treinamento em serviço (LEMLE, 1989, p. 330).

Em 1910, FLEXNER publicou um documento que resultou da inspeção realizada nas escolas médicas americanas, de forma a contribuir com a identificação de problemas e deficiências nos métodos de ensino. O Relatório Flexner é entendido como um divisor de águas em relação à educação médica ao revolucionar e irradiar seus princípios de forma contundente tanto nos Estados Unidos como na Europa. Seu impacto pode ser atribuído ao fato de propor os elementos seminais que deveriam orientar a formação do médico: os processos de racionalização e objetivação, o treinamento em serviço e a pesquisa científica. De acordo com LEMLE (1989, p. 331),

o Relatório Flexner significava o descredenciamento do ensino médico meramente tecnológico, na melhor das hipóteses, ou mesmo místico-artesanal, na pior das hipóteses, que vinha sendo praticado. Era a investidura do médico com as responsabilidades do cientista. Já não era possível licenciar um médico para a prática sem que estivesse armado com os métodos indispensáveis para o seu trabalho.

Outra questão importante, que deve ser assinalada, refere-se à própria estrutura física das escolas médicas, que deveriam garantir a consecução do princípio da pesquisa com o auxílio indispensável de laboratórios. "Se a nossa posição está correta, a enfermaria e o laboratório são, logicamente, do ponto de vista da investigação, tratamento e educação, inextricavelmente entrelaçados; a questão da precedência é fútil." (FLEXNER, 1925, citado por LEMLE, 1989, p. 331).

É oportuno reconhecer neste Relatório a raiz de uma metodologia moderna de treinamento médico que se baseia na resolução de problemas, inspirando mudanças curriculares com forte impacto na formação em muitas escolas, inclusive no Brasil. 
A crítica que comumente se faz ao Relatório Flexner fundamenta-se na compreensão de que a formação médica voltada para as demandas atuais hipertrofiou as competências técnicocientíficas em detrimento da relação médico-paciente e do compromisso social do médico. Cabe destacar que em alguns centros dos EUA, Alemanha e Inglaterra a pesquisa teve apoio político e financeiro tanto para se institucionalizar como para se profissionalizar, através de um lento processo de integração acadêmica nos hospitais universitários (MILLER, 1966, citado por LEMLE, 1989, p. 332).

Cerca de meio século depois, registrou-se uma nova etapa na educação médica de inspiração flexneriana, com base na ciência e na pesquisa, configurada por uma crescente crítica a este modelo. Algumas transformações seriam desencadeadas, a partir de 1960, "em conseqüência da expansão do ensino, das mudanças no sistema de saúde e de ações de ordem acadêmica, de responsabilidade das escolas."(FRAGA FILHO, 1988, p. 27).

Para melhor compreendermos como se deu este processo, vale destacar as inflexões ocorridas ao longo do século XX que marcam a recomposição da prática médica, destacando seus principais movimentos a partir da necessidade de se construir novas práticas em saúde que pudessem responder de forma mais eficiente às necessidades da população.

O surgimento da Medicina Preventiva nos Estados Unidos se atrela diretamente ao problema dos altos custos da atenção médica nas décadas de 30 e 40 - associada à questão tecnológica que passa a predominar na época. Temos, portanto, setores da população alijados da possibilidade de consumir esses serviços médicos, de tal forma que passa a ocorrer "a emergência de uma série de propostas, visando responder aos problemas da redução e racionalização dos custos excessivos da atenção médica, da ampliação dos serviços de 
saúde pública e atenção materno-infantil, do aumento de recursos hospitalares, além de outras" (ALVARENGA, 1984, p. 81).

Cumpre notar a importância que o conceito de risco e a identificação em seus vários níveis adquire como ponto de partida para a elaboração de propostas no seio do movimento preventivista. De acordo com ALVARENGA (1984) o emprego deste conceito para a prática médica "emerge como elemento essencial de uma análise da relação custo-benefício" (p. 83), respondendo às pressões oriundas das deficiências do setor.

Outro ponto importante, que merece destaque no que tange às críticas em relação à prática médica refere-se à área de Saúde Materno-Infantil constituir-se como um objeto tanto para a Medicina Tecnológica (diagnóstico e controle deste grupo de risco) como para a Medicina Preventiva (que emergia e adquiria consistência na época) e para a Medicina Integral. Estas últimas traziam no seu bojo uma forte crítica à prática médica predominante. De acordo com Donnangelo (apud ALVARENGA, 1984) a aproximação entre a Medicina Preventiva e Medicina Integral pode ser apontada a partir de dois aspectos fundamentais. Por uma parte, pela fragmentação do objeto individual que resulta do desenvolvimento das especialidades e de suas interferências, contradizendo uma concepção globalizadora deste objeto. E por outra, pela "fragmentação do processo de doença, consubstanciada no corte entre ações terapêuticas e preventivas, pelo qual o processo saúde-doença aparece despojado de seu caráter de temporalidade e de seu campo (ecológico e social) de constituição" (p.85).

Estes movimentos, que se consolidaram nas décadas de 50 e 60, revelam dois aspectos importantes que pretendemos destacar: a necessidade do descentramento do enfoque biológico intrínseco ao ato médico e da inclusão do paciente em um campo de relação, nos quais ganham relevo a família, o conjunto de fatores que contribuem para o surgimento da doença e sua interação, numa palavra: o social. 
Conforme já apontado, em função da natureza dos problemas com que trabalha, a Saúde Materno-Infantil incorporou as novas concepções oriundas da Medicina Integral e Preventiva ao pensamento clínico, dando consistência a possibilidade da presença do social no interior desta prática. Em decorrência desta especificidade, notamos no percurso histórico a abertura de perspectiva em torno de um novo projeto de recomposição da prática médica que surge na década de 60, qual seja, a Medicina Comunitária. A partir desta, Medicina e Saúde Pública passam a se relacionar de forma estreita, tanto na criação de estratégias de proteção a grupos populacionais (onde a mãe e a criança adquirem estatuto privilegiado) como na busca de integração de serviços de saúde num sistema único, conforme Sonis (apud ALVARENGA, 1984).

O delineamento de novas propostas de atuação no campo da saúde, a partir da década de 60 , enseja não somente localizar os elementos responsáveis pela inadequação de suas práticas frente às necessidades de saúde da população, mas sobretudo buscar soluções. Temos, portanto, o desdobramento de novos modelos de organização da prática médica, tomando como base o cuidado dos grupos populacionais ao invés dos indivíduos. Conforme ressaltado por Donnangelo (apud ALVARENGA, 1984) "é como prática de saúde, como forma de prestação de serviços, que a Medicina Comunitária se origina nos Estados Unidos e se difunde para as sociedades dependentes com o suporte das agências internacionais, tais como a Organização Mundial da Saúde e a Organização Panamericana da Saúde" (p. 104). Este movimento recupera os projetos da Medicina Integral e Preventiva, incorporando a prestação de serviços aos grupos excluídos da atenção médica devido à simplificação das técnicas de atendimento médico.

Nesta época, uma série de documentos importantes foram produzidos nos EUA, Inglaterra, França e América Latina, com o suporte da Organização Mundial de Saúde (OMS) e da Organização 
Pan-americana da Saúde (OPS), centrados nos problemas da formação médica. Destacou-se o Relatório Coggeshall (1965), que procurava enfatizar a importância da relação médico-paciente e do envolvimento do médico em experiências comunitárias, conhecidas como "extra-muros".

No entanto, conclui-se nesta análise a importância de se associar um trabalho de pesquisa de alto nível com um treinamento voltado para o paciente e para a comunidade, que nos dirige à discussão de que não existe contradição "entre a prática e o treinamento médicos comprometidos com a pessoa do doente e a sociedade por um lado, e a investigação científica pelo outro" (LEMLE, 1989 , p. 333).

\subsection{O ensino médico no Brasil}

Cabe apontar alguns dos elementos mais importantes que marcaram o ensino de Medicina no Brasil, para melhor analisar seus efeitos e desdobramentos.

De acordo com LIMA-GONÇALVES (2002, P. 114-5), "o ensino médico no Brasil começou com a chegada da família real portuguesa ao Brasil em 1808: menos de um mês depois de ter desembarcado em Salvador, por determinação do príncipe regente D. João VI, foi criada naquela cidade a primeira Escola de Medicina no Brasil". Em 1832, foi transformada em Faculdade de Medicina. A mudança da família real para o Rio de Janeiro determinou a implantação de outra escola médica.

Em pesquisa realizada por este autor, nos primeiros vinte anos do século $X X$, novas escolas foram criadas de forma equilibrada: uma na região Norte (Belém, 1919), duas na região Nordeste (Salvador, 1832 e Recife, 1920), quatro na região Sudeste (duas no Rio de 
Janeiro, 1832 e 1912; São Paulo, 1913; Belo Horizonte, 1918) e duas na região Sul (Porto Alegre, 1898 e Curitiba, 1912).

Entre os anos 1920 até 1960, mais 20 escolas foram criadas, das quais apenas quatro datam de antes de 1950, em que pese o fato de ter surgido nove na região Sudeste e apenas uma na região Centro-Oeste.

No período seguinte, entre 1961-75, ocorreu uma verdadeira explosão com a implantação de 44 novas escolas médicas, revelando uma enorme desproporção em termos das regiões do Brasil (27 no Sudeste) e da criação em municípios com importante representação política, a despeito de necessidades de ordem populacional, por exemplo.

Este crescimento desordenado apontou para uma situação preocupante quanto à responsabilidade pelo nível de qualificação de docentes, estrutura material para a realização do ensino, enfim, pelo compromisso quanto à qualidade de ensino e pesquisa.

Entre 1976-99, mais dezenove escolas foram fundadas, reproduzindo uma distribuição bastante desigual já anunciada pelos períodos anteriores. Em 1999, o número oficial de escolas médicas em nosso país totalizava 92 , com a presença de mais de $50 \%$ das escolas na região Sudeste.

Embora a OMS defina como satisfatório o número de um médico para cada mil habitantes, é válido notar que a média para o Brasil aponta para um índice de 1,22, sendo de 0,53 para o Norte e de 1,70 para o Sudeste, demonstrando a heterogeneidade e a complexidade da análise deste tipo critério, acrescido do fato de que o número de médicos per si não garante padrão de saúde para uma coletividade.

Um outro aspecto a ser destacado refere-se ao papel das Santas Casas, que reproduziam um modelo arraigado da tradição portuguesa, no qual um "hospital da comunidade era mantido e dirigido por integrantes da sociedade local e destinado 
essencialmente ao atendimento dos indigentes" (LIMA-GONÇALVES, 2002 , p. 120). Indivíduos doentes que podiam pagar pelo atendimento utilizavam-se desse serviço, pois em muitos locais tratava-se da única instituição para este fim, além do fato de que ali se encontravam os melhores e mais bem preparados profissionais de saúde.

Em sua pesquisa, LIMA-GONÇALVES (2001, p. 119) pôde verificar que as Santas Casas estiveram presentes na fundação de $55 \%$ das escolas médicas no Brasil. O autor sugere que para se tentar esboçar um perfil da escola médica no Brasil deve ser considerado o contexto em que foram criadas as primeiras escolas até a década de 1920, pois "todas elas obedeceram, em sua origem, a um padrão semelhante, tendo se desenvolvido a partir de um hospital-escola, representado por uma Santa Casa" (p. 125). Uma diferença marcante, no entanto, deve ser notada: as escolas de Salvador e Rio de Janeiro foram criadas por determinação do Príncipe-Regente, todas as demais ganharam vida a partir da iniciativa de médicos conceituados, muitos deles haviam estudado na Europa, e encontravam-se ligados a grupos representativos e de prestígio na comunidade.

Assim como todo o sistema de ensino superior no Brasil, durante a Primeira República, as escolas médicas sofreram forte influência francesa, com ênfase no treinamento profissional. Até o início do século $X X$, a pesquisa não era institucionalizada nos hospitais e ambulatórios onde se desenvolvia o treinamento médico. A pesquisa, exclusivamente aplicada, era realizada em alguns institutos com objetivos muito específicos - como o Instituto Bacteriológico e o Instituto Butantã, em São Paulo (LEMLE, 1989, p.334)

A padronização do ensino superior ocorreu somente em 1931, com a criação do estatuto das universidades brasileiras. No entanto, observou-se, neste momento, que a tarefa de resolver os problemas 
técnicos e científicos, através da pesquisa ainda ficava deslocada para os institutos, fora da universidade.

A criação da Universidade de São Paulo (USP), na década de 1930, é considerado um grande marco histórico na construção de um projeto de ciência para o Brasil. A oposição entre duas perspectivas, utilitarista ou acadêmica, revelava uma tensão importante, desde o início, no que concerce à tarefa essencial da universidade e de sua articulação com a sociedade.

Em 1934, a Faculdade de Medicina de São Paulo integrou-se à recém-criada USP. Em seus primeiros anos de existência, contou com a colaboração de mestres de renome, vindos da Europa, principalmente nas áreas básicas (Fisiologia, Anatomia, Patologia Geral e Higiene) fornecendo os alicerces para a estruturação de um perfil científico e moderno.

A partir de 1916, foi estabelecido um acordo entre a Santa Casa de Misericórdia de São Paulo, para que se pudesse exercer o ensino das cadeiras clínicas. Nessa mesma época, iniciou-se uma fértil e sólida parceria com a Fundação Rockfeller, com larga experiência em outros países na área de educação médica. Esta aliança permitiu a construção das instalações definitivas da faculdade e o intercâmbio entre docentes com escolas dos EUA e da Europa.

A atuação mais expressiva por parte do governo (do Estado) em relação a um projeto científico mais consistente só se fez presente em 1944, com a realização da construção do Hospital das Clínicas (HC) da Faculdade de Medicina da Universidade de São Paulo (FMUSP). Até este momento todo treinamento clínico e hospitalar era realizado na Santa Casa. O HC representou, indubitavelmente, uma transformação radical no ensino médico na medida em que passou a centralizar os setores básicos do hospital, operacionalizando e integrando os mais diferentes e necessários serviços - Radiologia, Patologia Clínica, Arquivo Médico, Estatística entre tantos (LIMAGONÇALVES, 2002, p. 125-28). 
Conforme já destacado, durante a década de 1950 alguns organismos internacionais desenvolveram estudos para atuar na formulação de propostas relacionadas a área de saúde. O modelo flexneriano demonstrava a importância de uma sólida base científica para sustentar uma prática de investigação conseqüente, no entanto, havia um enfrentamento a ser feito que revelava o abismo que se aprofundava no período pós-guerra no panorama mundial. Por um lado, nos países mais desenvolvidos, registrou-se uma grande explosão tecnológica e no outro extremo, os países em desenvolvimento padeciam de precários indicadores de saúde da população, indissociavelmente relacionados a sua política econômica.

A OPS divulgou, em 1970, um estudo específico sobre o mapeamento da educação médica na América Latina, realizado por pesquisadores de 12 países, concluindo a necessidade de que o "planejamento da formação dos recursos humanos em saúde deveria constituir parte importante dos planos nacionais de saúde e refletir os esforços coordenados de todas as instituições que tenham a ver com a formação e a utilização do pessoal de saúde" , conforme Garcia (apud FEUERWERKER, 1997, p. 38).

É importante assinalar que o processo de urbanização no Brasil se intensificou significativamente nas décadas de 1960-70, houve uma grande expansão da economia e, consequentemente, a incorporação de camadas da população gerando uma demanda crescente aos serviços de saúde, bem como de outros bens e serviços, sobretudo nos grandes centros urbanos. Sabemos que a resposta a esta necessidade foi marcante quanto à criação desordenada de escolas médicas nesse mesmo período, no entanto esta proliferação de profissionais correspondeu muito mais a uma lógica de mercado, com finalidades de lucro, do que o compromisso com qualidade e necessidades da população. (FEUERWERKER, 1997, p. 49). 
Para se ter uma dimensão da necessidade de se compreender os problemas relativos à educação médica, citamos o estudo intitulado Marco conceptual da educación médica en la América Latina, realizado por ANDRADE, com o apoio da OPS, em 1978. De acordo com FEUERWERKER (1997, p. 45) "foi a partir deste trabalho que as relações entre prática médica e educação médica ficaram claramente estabelecidas". Destacamos, que nesta análise é possível entrever a associação marcante entre a formação médica e uma rede de relações bastante intrincada, determinada pelo próprio contexto em que esta se produz. Ou seja, "a estrutura social e econômica, a estrutura da prática médica, as relações internas do processo de produção de médicos, a ideologia predominante ao nível profissional"(FEUERWERKER, 1997, p.45).

Em 1991, a Fundação Kellogg lançou o programa UNI (uma nova iniciativa na educação dos profissionais de Saúde), produto da avaliação crítica das experiências de Integração Docente Assistencial na América Latina e que se traduziu como um desafio à realização de um projeto de mudança nas escolas de saúde, articulando universidade com serviços de saúde e com a comunidade. FEUERWERKER (1997, p. 87) aponta os princípios que nortearam a elaboração das propostas: "base epidemiológica, interdisciplinaridade, trabalho em equipe multiprofissional e o ensino/aprendizagem em serviço". No Brasil, cabe destacar a instituição da Comissão Interinstitucional de Avaliação do Ensino Médico (CINAEM) em 1991, contribuindo com a criação de instrumentos de avaliação e de estudos para detectar especificidades dos problemas locais e criar uma base consistente para a formulação de propostas que procuram reverter o quadro de crise atual. 


\subsection{A Residência Médica}

Durante a graduação em Medicina, é de fundamental importância a aprendizagem de conhecimentos - ponto de vista cognitivo - bem como o desenvolvimento de habilidades para realização de exames e procedimentos - ponto de vista psicomotor. Entretanto, "a característica mais distintiva do ensino em Medicina em relação a outras profissões é o aprendizado de atitudes que regem a conduta médica" (BACHESCHI, 1998, p. 369). Cumpre notar, segundo este autor, que, frente ao doente, o médico lança mão de inúmeros conhecimentos e habilidades aprendidos e assimilados para melhor definir suas hipóteses de trabalho, porém, a atitude a ser tomada para a resolução do problema envolve importantes aspectos afetivos próprios do médico, do doente, da família deste e muitas vezes, da compreensão de aspectos sociais e econômicos que serão envolvidos para o diagnóstico e tratamento. Esta combinação de conhecimentos, habilidades e sentimentos, que definirá a conduta médica, varia substancialmente para cada doente atendido, mesmo que a doença seja a mesma. (BACHESCHI, 1998, p. 369).

Registramos no percurso da educação médica a importância da aprendizagem prática, considerada essencial e exercida ao longo da história de maneira indissociável. Data de 1889 a criação do primeiro programa de Residência Médica, na Universidade John Hopkins, nos Estados Unidos. (BACHESCHI,1998, p. 369). Esta forma de treinamento foi tão bem-sucedida que multiplicou-se rapidamente nos EUA, tornando-se praticamente obrigatória para o exercício profissional a partir de 1930 .

A institucionalização da Residência Médica sistematizou uma forma de ensino que expõe o jovem médico, selecionado previamente por uma avaliação rigorosa de conhecimentos, a inúmeros serviços e supervisores cuja principal missão consiste em torná-lo apto ao 
desempenho da especialidade escolhida. A origem do termo, cabe apontar, refere-se ao fato de que o médico deveria residir na instituição em que o programa estivesse sendo desenvolvido, colocando-se à disposição do hospital em tempo integral para melhor acompanhamento da evolução dos doentes.

A Residência Médica é considerada, portanto, a melhor forma de aprimoramento e de especialização em Medicina, pois baseia-se no treinamento em serviço submetido à supervisão contínua, permitindo aquisições cognitivas que ocorre de maneira simultânea ao desenvolvimento de habilidades e vivências de atitudes, entendidos como elementos essenciais à prática médica (BACHESCHI, 1998).

No Brasil, o primeiro programa com as características da Residência Médica foi criado no HC, da FMUSP em 1944. Quatro anos depois, foi introduzida no Hospital dos Servidores do Estado no Rio de Janeiro. Gradativamente, todos os hospitais universitários e uma parte dos hospitais previdenciários passaram a adotar programas similares. Em 1958, a FMUSP criou o estágio hospitalar no sexto ano, com o nome de internato, que obedecia o regime de tempo integral; os estágios pós-graduados passaram a ser denominados Residência Médica. Entretanto, só se tornou obrigatória a partir de 1983 (BACHESCHI, 1998, p. 370).

O crescimento progressivo do número de vagas, em inúmeras escolas, sob forma de programas de Residência Médica, refletiu também a necessidade de se contemplar a especialização dos médicos recém-formados. A proliferação desordenada de escolas médicas, sobretudo nas décadas de 1960-70 foi plena de conseqüências: um grande contigente de médicos vinha de cursos de graduação pouco estruturados, com precárias condições materiais e técnicas, resultando numa base frágil para o exercício da profissão. Nesse sentido, a Residência Médica passou a ser vista como indispensável à complementação da formação médica. As instituições de saúde se beneficiaram com o trabalho do residente, na medida em 
que este contribui com o atendimento, multiplicando a capacidade de recursos humanos necessários à demanda de assistência, ao mesmo tempo que ocupa uma posição central para o elevado nível de produção de conhecimentos, ensino e pesquisa, desenvolvidos com excelência nos hospitais-escolas (FEUERWERKWER, 1997; BACHESCHI, 1998).

Até 1973 , cerca de $50 \%$ dos médicos formados na FMUSP completavam sua formação através dos programas de Residência Médica oferecidos pela instituição. Entre 1975-76, este número saltou para a faixa de 90 a 95\%, conforme Sampaio (APUD FEUERWERKER 1997, p. 99). Como não existia nenhuma forma de regulamentação oficial desses programas, verificou-se uma multiplicação vertiginosa desta modalidade de trabalho em inúmeros hospitais, que ofereciam vagas "apenas para atrair mão-de-obra barata, sem qualquer intenção de propiciar aprendizado, fazendo com que o residente trabalhasse sem qualquer supervisão" (BACHESCHI, 1998, p. 370).

Os próprios médicos-residentes foram atores importantes na deflagração de um movimento nacional em torno de reivindicações para o exercício dos programas, bem como para a garantia de direitos trabalhistas, que culminou na criação da Comissão Nacional de Residência Médica (CNRM), através de decreto presidencial em 1977.

A constituição da CNRM foi referendada pela Lei 6932 de 1981, regulamentando a Residência Médica e definindo-a como

modalidade de ensino de pós-graduação destinada a médicos, em nível de especialização, caracterizada por treinamento em serviço, em regime de dedicação exclusiva, em instituições de saúde, universitárias ou não, sob a orientação de profissionais médicos de elevada qualificação ética e profissional (FEUERWERKER, 1997, p. 100-101).

Definiu-se, a partir de então, que os programas deveriam ser credenciados pela CNRM, que ao médico seria atribuído um título de 
especialista na conclusão do programa, referendado pelo Ministério da Educação e Cultura (MEC) e que haveria uma bolsa mensal durante o programa, com um valor definido por lei. Registrou-se apenas 154 pareceres favoráveis às 205 instituições que solicitaram credenciamento à CNRM, nessa ocasião, gerando uma diminuição de vagas, seguido por um novo fenômeno de expansão nos anos seguintes. Em 1982, havia 1500 vagas para residentes, elevando o índice para 4097 em 1984. (FEUERWERKWE, 1997, p.101).

A partir de 1989, o Conselho Federal de Medicina (CFM) e a Associação Médica Brasileira (AMB) passaram a estabelecer exames promovidos pelas associações de especialistas, como requisito para a obtenção de título de especialistas, instituindo um sistema de avaliação para coibir os reflexos dos inúmeros e precários programas de Residência Médica disseminados pelo país.

De acordo com a pesquisa realizada por FEUERWERKER (1997, p. 107), foi possível concluir que "a CNRM evoluiu muito pouco na organização e sistematização dos dados sobre Residência Médica no país, (...) não investiu na definição de critérios e requisitos mínimos para os programas nas várias especialidades, (...) avançou insatisfatoriamente no estabelecimento de relações com o MEC, com o Ministério da Saúde e também com as sociedades de especialistas".

Entre 1987-97 formaram-se em média 7167 médicos ao ano em todo o país, tendo sido oferecidos 4646 vagas para o primeiro ano de Residência Médica, portanto, para 65\% dos recém-formados. De 1981 até 1992 a CNRM credenciou 28580 especialistas, metade dos residentes formados corresponde às áreas básicas, liderados pela Pediatria (FEUERWERKER, 1997, p. 113).

Considerando alguns fatores que foram apontados para a compreensão do cenário atual em relação a área da saúde, convém reafirmar a importância de se operar na transformação da educação médica como requisito básico para um redirecionamento das práticas de saúde. Concluindo com FEUERWERKER, 
como momento privilegiado do treinamento clínico dos médicos e em função de sua interface com a prestação de serviços de saúde, a Residência Médica pode cumprir um papel importante nessa redefinição. Pode servir como cenário favorável à reorientação da interação/integração entre universidade e serviços e como palco de construção de novas práticas sanitárias (1997, p. 199-200). 


\section{Uma experiência de ensino com residentes de Pediatria}

Considerando o panorama realizado sobre a Educação Médica e a importância da Residência Médica como um instrumento fundamental de formação para a prática de saúde, cabe-nos apresentar a instituição onde nosso trabalho é desenvolvido e levantar algumas questões que serão objeto de nosso estudo.

\subsection{O Departamento de Pediatria da Faculdade de Medicina da Universidade de São Paulo}

O primeiro Professor Catedrático de Pediatria da FMUSP foi o Prof. Delfino Pinheiro de Ulhôa Cintra, que exerceu a cátedra entre 1917 e 1945, por ocasião de aposentadoria compulsória. Considerado "um excelente clínico que também assistia crianças", não era pediatra e foi escolhido por Arnaldo Vieira de Carvalho. A partir de 1946, o Prof. Pedro de Alcântara, professor da Escola Paulista de Medicina e da Faculdade de Higiene e Saúde Pública de São Paulo, submeteu-se a concurso com banca examinadora, regendo a cátedra até 1964 . (MARCONDES, 1990, p. 6).

Durante cerca de duas décadas, o Prof. Pedro de Alcântara foi responsável pela criação das condições necessárias para estruturação do Departamento de Pediatria, que ocorreria muitos anos depois devido aos inúmeros requisitos exigidos pelo Estatuto da Universidade. Seu grande mérito, entretanto, deveu-se ao fato de ter difundido uma doutrina de assistência à criança fortemente sedimentada numa cultura humanística, atribuindo ao pediatra a função de educador, centrado na preocupação com o bem-estar da 
criança e na ênfase dada aos aspectos emocionais e psíquicos, "numa época em que não se cogitava sequer a psicologia ou a psiquiatria infantis" (MARCONDES, 1990, p. 13).

A instalação de serviços como a Seção de Higiene Mental, Pronto Socorro de Pediatria, Laboratório, Berçário Anexo à Maternidade, Biblioteca, Internato no $5^{\circ}$ e $6^{\circ}$ anos e Residência em Pediatria podem ser apontados como empreendimentos relevantes para a consolidação da especialidade no contexto da FMUSP, que criou o atual Departamento de Pediatria em 1978. As atividades relativas à área foram desenvolvidas desde o início da Faculdade até 1971, sob a alcunha de Cátedra de Pediatria e Puericultura. Com a reforma da Universidade (1970-71), esta cátedra ficou incorporada ao Departamento de Clínica, com três disciplinas: Pediatria Preventiva e Social, Pediatria Clínica e Pediatria Neonatal.

Entre 1964-1990, assumiu a cátedra o Prof. Eduardo Marcondes, filho de Pedro de Alcântara e protagonista da divulgação dos princípios que nortearam a referida concepção da prática pediátrica, graças a inúmeros empreendimentos e realizações, também como chefe do Departamento. Entre eles, cabe destacar a fundação do Instituto da Criança (I.Cr.), integrando o "Complexo Hospital das Clínicas", a criação do Centro de Saúde-Escola do Butantã (CS-E), do Hospital Universitário (HU) da USP, bem como o aprimoramento do curso de graduação em Pediatria, da Residência em Pediatria e da implantação da Pós-Graduação em Pediatria na FMUSP.

Os níveis de ensino de assistência à criança na área médica passaram, portanto, a ser exercidos na graduação, na pós-graduação (sentido lato, como residência médica e sentido estrito, como mestrado e doutorado), na complementação especializada e por médicos-observadores nos serviços tanto do $\mathrm{HC}$, como em outros espaços físicos fora do complexo. 
Em documento denominado Carta do Embu, de 1978 (MARCONDES, 1978), vários profissionais do Instituto da Criança reuniram-se para discutir e formular uma proposta de organização administrativa do Instituto da Criança que pudesse contemplar seus principais objetivos. Neste texto, fica amplamente explicitado a idéia básica de assistência global da criança (nomeada a "regra de ouro" em Pediatria) apoiada no trabalho de equipe multiprofissional, nos níveis de assistência, ensino e pesquisa (p.90-1).

A tese central deste texto sustenta que o ensino da Pediatria geral, considerada a linha-tronco do ensino de assistência à criança, realiza-se graças à formação fundamental - atenção e assistência à crianças e adolescentes, na faixa de 0 a 20 anos que apresenta as doenças mais freqüentes e a formação complementar - assistência a essa população que apresenta patologias especializadas. Considera como áreas complementares indispensáveis: Higiene Mental, especialidades, recursos subsidiários de diagnóstico e terapêutica e administração.

Quanto à Higiene Mental, ocupa posição peculiar no I.Cr., (....) é doutrinária a presença do Serviço de Higiene Mental em muitas áreas do I.Cr. (....) Sua presença é prioritária nas áreas de formação fundamental. O objetivo principal é, através do processo de assessoria, contribuir para a formação de um pensamento pediátrico psicossomático sem o que não se cumprirá o primeiro item dos objetivos do I.Cr. que diz ser necessário a Pediatria abranger os problemas orgânicos e psíquicos da criança. (MARCONDES, 1978, p. 92) 


\subsection{Do Serviço de Higiene Mental ao Serviço de Psiquiatria e Psicologia do Instituto da Criança}

O Serviço de Higiene Mental do I.Cr. foi criado pelo Prof. Pedro de Alcântara, em 1955, nos moldes das Child Guidance Clinics norteamericanas, tendo se constituído desde o início por equipe multiprofissional, composta por psiquiatra, psicólogo e assistente social. Com a função de assessorar o ensino e a assistência na clínica pediátrica, fundamentou-se no princípio preconizado pela OMS, que definiu, em 1952, Higiene Mental como consistindo nas atividades técnicas que promovem e mantém a Saúde Mental, esta última conceituada como a capacidade do indivíduo integrar-se num grupo (DIAZ e ROGONE, 1990, p.273).

A psiquiatra Dulce Machado desenvolveu, juntamente com os colegas Oswaldo Di Loretto e Stanilslau Krynski, uma abordagem de problemas pediátricos sob forte influência das correntes psicodinâmicas e sociais da época, assumindo a chefia da equipe da sua fundação até 1980 .

Durante uma primeira fase deste Serviço, que se estendeu por cerca de duas décadas, predominava a concepção de causa e efeito no conjunto das atividades técnicas, mimetizando a postura médica de buscar causas somáticas para o comportamento das crianças com queixas psíquicas, que eram encaminhadas para o Serviço. Além de uma excessiva psicologização da prática pediátrica, ocorria uma espécie de casamento perfeito entre a instituição e o serviço, na medida em que este respondia às demandas de tratamento e cura.

Numa outra etapa, de acordo com MACHADO (1980), citado por DIAZ e ROGONE (1990, p. 274), "houve um deslocamento do trabalho em função do sintoma para o campo da relação médicopaciente e da relação mãe-filho, tanto com o objetivo psicoprofilático como por convicção de que o modelo médico deixa de ser útil no terreno da psicologia e da psiquiatria". É apontado o efeito provocado 
na instituição por esta nova postura, gerando descrédito em relação ao Serviço "que tentava deixar de responder à demanda de forma mágica e onipotente, como havia feito até então"(p. 274).

Em meados da década de 1970, o Serviço passou a receber psicólogos-estagiários, com o intuito de aprimoramento de forma voluntária, embora submetidos à seleção rigorosa. Duas décadas depois, estes passaram a receber bolsas-auxílio fornecidas pela Fundação do Desenvolvimento Administrativo (FUNDAP), subordinada à Secretaria da Administração do Governo de São Paulo, regulamentando esta modalidade de aprendizagem quanto aos aspectos trabalhistas, critérios de avaliação etc.

A despeito da ausência de Dulce Machado da função de coordenação da equipe, a partir da década de 1980, a equipe manteve uma postura bastante ativa quanto à participação de seus membros nas diversas unidades do I.Cr., preservando o ideário pautado no trabalho em equipe multiprofissional. A pesquisa clínica avançou devido ao aprofundamento dos estudos e discussões sobre a especificidade da prática psicanalítica na instituição médica aliada a uma atmosfera bastante favorável determinada por experiências mais sistematizadas em Saúde Mental, desencadeadas pelo governo estadual (Montoro, 1982-86) e municipal (Erundina, 1988-92), pela propagação da luta anti-manicomial e pela expansão de cursos de formação na área de psicologia, psiquiatria, psicanálise e afins.

A década de 1990, por sua vez, foi marcada por um grande incremento em relação ao suporte tecnológico na instituição, modernização de suas instalações e ampliação da assistência para convênios e particulares. Houve a expansão do número de vagas para a Residência de Pediatria e um declínio vertiginoso da importância dada ao trabalho em equipe multiprofissional.

Assistimos, de forma gradativa, a um esvaziamento das equipes nas mais diversas unidades, provocada por questões econômicas (devido a uma política salarial catastrófica, reiterada por sucessivos 
governos), reduzindo sua composição aos campos da Medicina e Enfermagem. Áreas como Serviço Social e Nutrição, por exemplo, passaram a concentrar o atendimento das demandas próprias da instituição, de forma localizada e pontual, descaracterizando o espírito de equipe, fundamentado no debate e na pesquisa em torno de temas comuns.

O Serviço de Higiene Mental teve vários de seus profissionais deslocados para outros serviços do Complexo HC, sofrendo uma significativa redução do contingente da equipe. Houve apenas um concurso público para admissão de psiquiatra e outro para contratação de psicólogo nos últimos quinze anos.

Em 2002, chefiado pela primeira vez por uma psicóloga, Vera Ferrari Rego Barros, o serviço foi renomeado oficialmente como Serviço de Psiquiatria e Psicologia (SPP), despojando-se da concepção ultrapassada de higiene mental e procurando afirmar-se, na busca de uma identidade própria, a despeito das adversidades apontadas.

Estes deslizamentos ao longo da história tiveram desdobramentos em relação às atividades de ensino, sob responsabilidade da equipe que sempre procurou delimitar um campo teórico e prático consistente e compartilhado pelos seus membros. É oportuno assinalar que a referência à Psicanálise constituiu um marco conceitual permanente, atravessando a história do grupo, em que pesem divergências próprias a este campo.

Em relação ao ensino em Pediatria, sempre houve um grande investimento por parte da equipe do Serviço em relação ao programa desenvolvido com residentes em Pediatria, compreendido como estratégico para a aprendizagem e disseminação sobre temas em Saúde Mental.

Nesse sentido, ao longo de toda a história da instituição as atividades de ensino com os residentes foram sustentadas pelo Serviço, dentro de uma programação que previa uma carga horária 
expressiva em conjunto com os psiquiatras e psicólogos da equipe, durante o primeiro ano de Residência.

Esta atividade era realizada com grupos de 16 residentes (passando para 20 em meados dos anos 90, com o aumento de vagas), subdivididos em dois grupos de 8 (passando para 10, posteriormente) coordenados por um membro da equipe de Higiene Mental, durante um semestre. No seis meses sequintes, uma nova turma era recebida nos mesmos moldes. A programação sofreu inúmeras modificações no decorrer do tempo, entretanto, o eixo central consistia na transmissão de conceitos da teoria psicanalítica, com 0 objetivo de instrumentalizar 0 pediatra a ampliar 0 entendimento sobre a clínica, problematizando- a. Noções como inconsciente, discurso familiar, estruturação subjetiva, sintoma, entre outros, eram trabalhadas com os subsídios de aulas expositivas, leituras de textos, discussões e apresentações de casos. Recursos como projeção de filmes que aborda temas como anorexia, psicose, adoção, seguido de debates foram amplamente utilizados.

Este programa era complementado pela participação dos profissionais da equipe no estágio do Ambulatório Geral (cujo objetivo consistia no treinamento clínico das doenças mais freqüentes em Pediatria no I.Cr., realizados sob supervisão). Esta participação limitava-se a uma atividade conhecida como "preparo de casos", que ocorria semanalmente em pequenos grupos compostos por residente, médico-assistente, profissionais de outras áreas (inicialmente uma equipe multiprofissional completa), com o intuito de discutir em profundidade os casos que seriam atendidos na semana seguinte pelo residente. Nesta ocasião, o profissional da Higiene Mental contribuía com seus aportes, já que alguns casos eram encaminhados para o Serviço para avaliação e tratamento.

Em 2001, ocorreu uma reformulação importante no Programa de Residência Médica em Pediatria, como conseqüência de fóruns de avaliação do programa vigente, organizado pela Comissão de Pós- 
Graduação Senso Lato (CPGSL), "em vista das novas necessidades de saúde pública do país e do desenvolvimento tecnológico da medicina" (DINIZ e JACOB, 2001, p. 2). Os fóruns, que ocorreram ao longo do ano de 2000, contaram com a participação e representação de todos os segmentos envolvidos no ensino: residentes, docentes, assistentes e professores titulares do Departamento de Pediatria.

Inúmeras mudanças foram propostas e implementadas no ano seguinte, das quais destacamos o deslocamento de uma boa parte do ensino na Residência para as atividades ligadas à atenção primária e secundária, realizadas em serviços fora do I.Cr., sobretudo no primeiro ano e a mudança do Ambulatório Geral (AGEP) para HU da USP. O I.Cr. passou, portanto, a albergar todas as atividades relacionadas à atenção terciária, assumindo sua vocação para área de especialização, tratamento e pesquisa desses níveis, que já vinha se desenhando de forma irreversível.

No entanto, cumpre assinalar que esta iniciativa de ampliação da carga teórica e prática em nível ambulatorial e de intervenções junto a comunidade apontou para um entendimento do processo saúde-doença de forma mais dinâmica e complexa, por parte da instituição, que reconheceu a excessiva concentração de programas da residência no hospital. Durante a realização dos fóruns,

houve a discussão a respeito de qual o limite entre a área de atuação do pediatra geral e a necessidade de formação a nível de atendimento terciário, mais especializado, característico do desenvolvimento das várias áreas médicas. Ainda dentro deste tema, foi afirmada a necessidade de um treinamento ambulatorial contínuo, em complexidade crescente, durante toda a residência médica, começando pelas áreas de atenção primária, seguida pelas áreas secundárias de atuação e depois nos ambulatórios especializados (DINIZ e JACOB, 2001, p. 2-3). Nesse sentido, a partir da experiência do Serviço de Higiene Mental na área de ensino de residentes e a da necessidade de 
acompanhar as transformações da instituição, pareceu-nos prioritário preservar e sustentar o trabalho relativo à formação do médico. Para realização de tal objetivo, uma psicóloga do Serviço (no caso, a autora deste trabalho) foi deslocada para o CS-E e uma psiquiatra foi para o AGEP, para a implementação de uma nova proposta de ensino na área de Saúde Mental para o médico-residente em Pediatria.

\subsection{Uma proposta de ensino: a subjetividade em questão}

A proposta do SPP para as atividades que passaram a ser desenvolvidas no CS-E encontrou ressonância e fundamentação em algumas referências importantes extraídas do Informe Preliminar sobre o ensino de Pediatria nas escolas de Medicina na América Latina, realizado pela Associação Latino Americana de Pediatria (ALAPE), em 2000 (PUGA e col, 2000).

Em primeiro lugar, cumpre assinalar a importância das mudanças no setor de saúde, na América Latina. Especificamente, no que tange à saúde da criança,

estima-se que no continente americano morrem $200 \mathrm{mil}$ menores de cinco anos e, apesar de alguns progressos alcançados nesse campo, muitas desigualdades regionais persistem tornando esse número ainda mais intolerável. A análise das causas dessas mortes revela que, em média, uma em cada três decorre de doenças para as quais existe prevenção e/ou possibilidade de diagnóstico e tratamento precoces (PUGA e col, 2000, p. 302).

Atualmente, a grande parte das demandas dirigidas ao pediatra nos serviços de saúde ( $50 \%$ a $70 \%$ das consultas e $30 \%$ a $60 \%$ das internações das crianças) ocorre por doenças das quais se conhecem os fatores de risco, bem como as razões que contribuem para uma taxa de mortalidade tão expressiva. Convém lembrar que este 
conjunto é formado principalmente por: infecções respiratórias agudas, doença diarréica, desnutrição, meningite, sepse, sarampo e malária (PUGA e col, 2000, p. 304).

Embora o hospital tenha sido, tradicionalmente, o "eixo coordenador" do aprendizado, consubstanciando a fonte de prática básica quase única do futuro profissional, cabe afirmar que esta formação não corresponde à realidade na qual o profissional irá atuar, conforme apontamos, pois a grande parte destes pediatras encontrarão sua inserção profissional nas áreas primária e secundária (postos de saúde, ambulatórios e serviços vinculados diretamente às comunidades). Neste sentido, de acordo com PUGA e col (2000), urge "a necessidade de se rever os conteúdos a serem ministrados e as habilidades a serem adquiridas de modo a fazer com que o futuro médico se forme com uma nova filosofia de atenção à saúde" ( $p$. 304).

A definição dos parâmetros básicos do ensino médico podem ser resumidos ao desenvolvimento da capacidade do profissional voltada para "a assistência aos problemas familiares numa sociedade em fase de mudança". Ou melhor: "a ênfase é colocada no conhecimento dos mecanismos que levam à enfermidade, integrando as ciências básicas com a prática clínica, o conhecimento do ambiente e os condicionantes sociais, a concepção holística do indivíduo, abarcando os cuidados de saúde numa perspectiva mais ampla, indo desde a sua prática até os hábitos de vida" (PUGA e col., p. 304).

A construção de uma prática pediátrica que contemple a singularidade do indivíduo e considere a importância das determinações sociais, econômicas e psicológicas passou a traduzir o enorme desafio para os profissionais historicamente comprometidos com o ensino em Pediatria. A questão que se coloca refere-se à possibilidade de se construir uma prática médica que articule as questões subjetivas da criança e da família aos problemas que são dirigidos ao pediatra. Este pode ser definido como o principal eixo do 
trabalho que passou a ser desenvolvido no CS-E e que será problematizado neste trabalho, uma vez que esta proposta foi apresentada em reunião da CPGLS, no dia 26 de outubro de 2001, passando a vigorar no ano seguinte, coordenados pela psicóloga do SPP e autora desta dissertação.

Esta atividade nomeada "Saúde mental da criança" passou a ser desenvolvida no contexto do estágio de "Pediatria Comunitária", realizada no CS-E com duração de 10 semanas, com grupos de 8 residentes que fazem rodízio, em outros estágios, ao longo do primeiro ano de Residência. Este estágio desenvolve ações na comunidade da área de abrangência do CSE (creche, escola, HU, domicílio) e conta com os médicos-assistentes e equipe de enfermagem do CSE, Assistência Comunitária do I.Cr. Trata-se, portanto, de um tipo de treinamento marcado por ações de prevenção, promoção e proteção da saúde, tendo como alvo a criança.

Nesse contexto, passamos a desenvolvê-la através de encontros semanais com o grupo de residentes (em um dia fixo da semana, com duração de 4 horas), cujos objetivos gerais podem ser sintetizados em dois grandes aspectos: o primeiro seria o de capacitar o residente a articular as questões subjetivas da criança e da família aos sintomas que são trazidos e problematizar essas demandas de intervenção e de resolução de problemas. $E$, por outro lado, propiciar ao residente o desenvolvimento da sua capacidade de reflexão e de senso crítico sobre sua ação, sua postura ética e seu papel social, utilizando como eixo para a análise a relação médicopaciente.

Para a consecução desta proposta, passamos a freqüentar alguns períodos no CS-E em que ocorrem os atendimentos feitos pelos residentes, sob supervisão, a fim de tomar contato com as dúvidas, dificuldades e impasses vividos pelos residentes durante 0 seu aprendizado na prática, em meados de 2001. A troca promovida 
pelas discussões e por nossas participações eventuais no atendimento, a título de entrevistar a criança e família junto com o residente, foram consideradas muito produtivas tanto pelos residentes como pela equipe, promovendo intercâmbio, discussão de condutas, sugestão de intervenções entre outros.

Em relação à atividade semanal, os temas escolhidos para dar corpo a esta proposta obedeceram uma lógica que partiu das teorias sobre o desenvolvimento da criança, com ênfase na constituição subjetiva e na função da família, desdobrando-se para os problemas clínicos mais freqüentes em Pediatria, no que faz interface com a esfera psíquica. Alguns colegas da equipe de Saúde Mental do CS-E participaram em todos os grupos ao longo do primeiro ano de implementação dessa proposta, em 2002, contribuindo com a discussão de temas, balizados por noções de Medicina Social e Preventiva, presentes no arcabouço teórico dessa equipe do CS-E, ligada ao Departamento de Medicina Preventiva da FMUSP.

No ano de 2003, algumas modificações foram introduzidas para dar consistência aos objetivos do estágio de Pediatria Comunitária, que tem procurado estruturar atividades que enfatizem as ações ligadas à atenção primária, rompendo com a tradicional visão assistencial, paliativa e curativa, bastante impregnada por efeito da própria formação, como já destacamos. Cumpre notar que a equipe do CS-E tem procurado transformar e refletir sobre sua contribuição no processo de formação do pediatra, de forma comprometida: a avaliação permanente e a discussão em equipe sobre o trabalho desenvolvido são os dispositivos mais utilizados, uma vez que uma parte importante do ensino em Pediatria da graduação da FMUSP ocorre nesse local, envolvendo todos os profissionais nessa tarefa.

Procuramos, então, reformular nossos objetivos que podem ser resumidos por: contextualizar a nossa atualidade para 0 entendimento do processo saúde-doença, considerando outros determinantes além do paradigma biomédico; oferecer instrumentos 
de leitura para o entendimento da prática médica enquanto prática social; fornecer aportes teóricos que possibilitem ao médico construir uma visão crítica sobre os sintomas da criança e a demanda da família, bem como elaborar intervenções que levem em contra a singularidade de cada caso.

O enfoque deste trabalho, até então voltado para as questões da clínica pautada no atendimento individual, foi redirecionado para a compreensão dos fenômenos coletivos que se referem à prática pediátrica utilizando instrumentos de leitura, com base em outras áreas do conhecimento como as Ciências Humanas e a Psicanálise. Alguns temas foram mantidos como a constituição subjetiva da criança, porém acrescidos de uma visão sobre a construção histórica do conceito de criança e uma discussão sobre a estrutura contemporânea da família a partir dos lugares do feminino e do masculino na nossa atualidade. Introduzimos a noção de "mal-estar na cultura" para articularmos com o conceito de processos de subjetivação próprios a cada época: os fenômenos psicopatológicos podem ser compreendidos a partir dessa contextualização, não somente como uma expressão individual desviante, por alterações bioquímicas. Os temas que foram sugeridos procuram contemplar os sintomas contemporâneos que se articulam à Pediatria: a mídia e a criança, a depressão, a violência, o fracasso escolar e a adoção.

Consideramos o processo histórico sobre a construção do campo da saúde da criança como um instrumento importante para compreender as raízes de um certo tipo de prática, sobretudo médica, cujo caráter racional e científico compõe o eixo direcionador. Apresentamos uma proposta de trabalho contextualizada no campo da Educação Médica, que nos instiga a questionar sua pertinência, seu alcance, seu potencial transformador. Temos como ferrramenta teórica a Psicanálise, que propõe uma concepção de sujeito (diferentemente da unidade biopsicossocial) que abre um enorme campo de discussões. 
Nosso entendimento é o de que o ser humano torna-se um sujeito a partir da sua inserção num mundo simbólico, mediado primordialmente pela mãe - ou por aquele que garantir sua sobrevivência - e assume sua condição de sujeito de desejo pela intervenção do pai - ou por aquele que assumir o lugar de representante da lei e da ordem. Estas duas funções, materna e paterna, são operadores necessários e suficientes para transformar o recém- nascido em sujeito. Neste sentido, não entendemos a criança apenas como um ser em desenvolvimento, mas como um sujeito que se constitui ou não (DEGENSZAJN, 2003).

Uma vez que cabe ao pediatra um papel fundamental de acompanhamento e orientação nos cuidados que a família dispensa à criança, parece-nos fundamental um trabalho de treinamento que considere a oportunidade de percepção de sinais e sintomas de problemas em fase bem precoce, gerando uma intervenção fundamental no curso da constituição subjetiva da criança e no imprescindível trabalho com os seus familiares. Como o pediatra é o agente externo principal na vida de uma criança, faz-se necessário torná-lo apto a intervir, sobretudo no âmbito da atenção primária, contemplando o trabalho de promoção e prevenção em saúde.

Procuramos trabalhar os conceitos que sustentam o campo propriamente psicanalítico, de forma a criar uma interlocução com as problemáticas enfrentadas pelo pediatra no cotidiano de seu trabalho.

Cabe lembrar que a atividade dirigida pelo referencial já explicitado, nos conduz a supor que os próprios residentes são, de uma forma ou de outra, tocados em sua própria subjetividade. Levando em conta este aspecto, iniciamos nosso trabalho com cada grupo propondo uma apresentação individual, em que cada residente discorre de forma livre e aberta sobre seu percurso, pontuando o que Ihe pareceu determinante em relação a sua escolha pela carreira médica. Solicitamos que este relate suas influências mais marcantes que contribuíram para a eleição do campo da Pediatria. Desta forma, 
é possível aproximarmos um pouco as inúmeras experiências de grupos geralmente muito heterogêneos, facilitando a comunicação entre os membros, explicitando as singularidades e abrindo um canal de trocas e intercâmbios que será importante para a realização das atividades posteriores.

Uma vez todo o grupo apresentado, distribuímos o programa subdividido em temas, com textos correspondentes e que são previamente distribuídos. A cada reunião, estes são preparados e apresentados pelos residentes, onde alguns pontos de discussão são levantados e a função da coordenação consiste em articular estes pontos às formulações teóricas que são enunciadas e resgatadas ao longo do programa, com o objetivo de dar contorno a um certo campo conceitual. Existe a abertura para a apresentação de casos, situações vivenciadas e todo o tipo de experiência trazida pelos residentes pertinentes aos temas. Estas são discutidas no grupo, onde se busca fundamentalmente o exercício de interlocução entre todos os componentes, bem como a construção de uma compreensão e de encaminhamento das questões pela coordenação. Eventualmente, frente a demanda de discussão de um tema específico, introduzimos o novo tema; tendo ocorrido inclusive a projeção de filme ou a discussão de uma leitura sugerida pelos próprios residentes. No final do programa, é solicitado que cada residente entregue, por escrito, uma avaliação do curso e uma reflexão sobre um dos temas, escolhido livremente.

Como uma boa parte deste material já se encontrava em nosso poder, recorremos para seu emprego como material de investigação ao termo de consentimento esclarecido, de acordo com as prerrogativas éticas para a realização de pesquisas com seres humanos, procurando os residentes que participaram de nossa atividade no ano de 2003 e pedindo sua autorização para o uso do material. Para que pudéssemos realizar a análise em tempo hábil, restringimos a três grupos de residentes no ano de 2004, dos quais 
também foi solicitado o referido termo de consentimento. Este material nos pareceu bastante rico no sentido de levantar pistas importantes sobre o alcance e a limitação dessa proposta. 


\section{Sobre o objetivo e a construção metodológica}

\subsection{O objetivo:}

Descrever e analisar os conteúdos da avaliação da atividade de ensino "Saúde Mental da Criança", realizada pelos residentes, que compõe o estágio "Pediatria Comunitária", desenvolvida no Programa de Residência Médica em Pediatria na FMUSP, procurando identificar seu alcance e limitação para a formação do pediatra no contexto de atividades de atenção primária de saúde, considerando, sobretudo, as possibilidades da inclusão da subjetividade da criança e da família, como parte do arsenal tecnológico empregados pelo mesmo no cuidado à criança.

\subsection{As avaliações como discursos e os residentes como sujeitos da experiência}

Em relação à descrição e análise que pretendemos empreender sobre os conteúdos da avaliação realizada pelos residentes, no final do estágio, cumpre fazer algumas considerações. O material em questão resulta do trabalho desenvolvido pela própria pesquisadora, que se coloca como autora, portanto deve ser assinalado a proximidade e o envolvimento concernentes à realização da tarefa. Partiremos, portanto, de um método de trabalho que recusa a noção 
de objetividade e/ou neutralidade para validá-lo. Concordamos com VIEIRA (1991), que afirma:

ao apresentar o caminho percorrido, trazendo à luz as evidências, o porquê de sua escolha, como foram tratadas, o pesquisador está trazendo, ao mesmo tempo, o lugar de onde fala e as implicações metodológicas de seus procedimentos. Neste caso, o produto final da pesquisa apresentará um conhecimento sobre o objeto e não o conhecimento".

Adotamos a abordagem qualitativa para procedermos à leitura, descrição e análise dos relatos escritos, conforme MINAYO (1994), que propõe o aprofundamento no mundo dos significados das ações e das relações humanas, contrapondo-se ao método perceptível e captável em médias e estatísticas, característico do tratamento quantitativo. O eixo central da investigação ancora-se, portanto, na questão da significação atribuída àquilo que foi vivido como aprendizagem, ao longo de nosso curso.

O material analisado é composto pelas avaliações feitas por escrito, realizadas pelos residentes no final do estágio e entregues à pesquisadora. Interessou-nos avaliar o período em que nossa proposta foi implementada a partir do contexto de mudanças ocorridas no Programa de Residência em Pediatria. Esta atividade iniciou-se em 2002, tornando-se parte integrante do estágio de 
Pediatria Comunitária nesse mesmo ano; tivemos, então, uma nova turma em 2003, já concluída, e um novo grupo, no ano de 2004.

Como cada grupo é composto por 8 residentes, temos no final de cada ano, 5 grupos que realizam o estágio, com duração de cerca de 10 semanas; ao final de cada ano, temos 40 avaliações realizadas. Por uma questão de cronograma de pesquisa, fizemos a análise de 3 grupos ao longo do ano de 2004. Como alguns residentes não entregaram a avaliação no final do estágio, nossa "amostra" totalizou 58 avaliações.

A escolha do material fundamentou-se no fato de constituir um material rico, pertinente ao processo de ensino-aprendizagem, no qual a atividade encontra-se inserida, de fácil coleta e que se articula ao nosso interesse principal, que é o de analisar a avaliação realizada pelos residentes ao final de nosso curso. Cabe lembrar que o texto produzido pelo residente é feito individualmente, no final do estágio, de forma aberta, mediante solicitação anunciada no início do curso, nos seguintes termos: "Faça uma avaliação sobre o curso "Saúde Mental da criança", considerando o estágio de Pediatria Comunitária, no qual ele ocorre. Descreva como você avalia os temas propostos, de que forma isto contribui para sua formação como pediatra e reflita sobre algum aspecto que lhe pareceu mais relevante."

Qualificamos nossa pesquisa como um estudo de caso de observação, pois o foco do estudo centra-se num aspecto particular 
de uma organização (no caso o Programa de Residência em Pediatria, ou mais especificamente, o estágio Pediatria Comunitária), no qual pretendemos analisar a avaliação realizada ao final do curso, formado por um grupo específico de pessoas (no caso os residentes ).

A idéia presente é a de que o material escolhido refere-se àquilo que os sujeitos escrevem por si próprios, podendo ser utilizados como dados, na medida em que pode servir "como fontes de férteis descrições de como as pessoas que produziram os materiais pensam acerca do seu mundo" (BOGDAN e BIKLEN, 1997, p. 176). A vantagem apontada por estes autores sobre esta modalidade de material consiste na oportunidade do investigador dirigir o foco e obter "um certo número de pessoas que escreva sobre um mesmo acontecimento ou tópico" (p. 177).

Compreendemos, ainda conforme BOGDAN e BIKLEN (1997), que nosso material oferece uma possibilidade de ser organizado de acordo com códigos de definição da situação, ou seja, sistematizar "conjuntos de dados que descrevam a forma como os sujeitos definem a situação ou tópicos particulares" (p. 223). Permitem demonstrar a visão que os sujeitos têm do mundo e de si mesmo, em relação ao tema em questão, como definem o que fazem, o que é importante para eles.

Importante ressaltar, ainda, a questão dos limites do estudo proposto, uma vez que este se inscreve em contexto bastante 
específico e particularizado por inúmeros determinantes. Cumpre notar, nossa preocupação em delimitar, de forma clara, o contexto no qual ele se desenvolve, em que pese também as particularidades relativas aos sujeitos envolvidos no trabalho da instituição, sua formação, interesses e expectativas. Nesse sentido, entendemos o método como "o exercício reflexivo de apreensão de uma dada realidade, ou como a expressão da relação sujeito/objeto, isto é, da forma como o pesquisador enquadra a realidade e nela se enquadra" (ADORNO e CASTRO 1994, p. 173).

\subsection{A escolha do discurso do sujeito coletivo como estratégia metodológica de discursos-síntese}

Nossa pesquisa procura não somente descrever, mas também analisar os conteúdos das avaliações produzidas pelos residentes sobre a atividade "Saúde Mental da Criança", no contexto de sua formação no Programa de Residência em Pediatria. Interessa-nos, portanto, "dar voz" aos sujeitos desta experiência. Isto tendo em vista que o que é pensado pode ser expresso sob forma de discurso, "porque os pensamentos pertencem à família das línguas e linguagens e, portanto, à ordem do discurso ou do texto" (VERON, 
1980 e MAINGUENEAU, 2000, CITADO POR LEFÈVRE E LEFÈVRE, 2003).

Neste sentido, utilizamos a estratégia tecnológica proposta por LEFÈVRE e LEFÈVRE (2003) que propõem a construção do que entende como sendo a expressão de um "sujeito coletivo" em pesquisas empíricas. Cumpre esclarecer que nossa concepção, por se referir a uma pesquisa qualitativa, não é a da possibilidade de que os discursos dos sujeitos possam ser generalizados nesta modalidade de pesquisa. Consideramos operacional adotarmos esta estratégia, ao concebermos sua expressão como resultado do que é passível de ser apreendido tanto como o que for homogêneo e significativo para a maioria dos sujeitos produtores das avaliações, quanto o que for heterogêneo partilhado por um ou poucos sujeitos. Daí, no presente trabalho, serem incorporados tão somente como discursos-síntese.

Para a construção do discurso deste sujeito coletivo procedemos à identificação das idéias centrais de cada depoimento, com suas correspondentes expressões-chave, para compormos um ou vários discursos-síntese, na primeira pessoa do singular. O pressuposto básico de LEFÈVRE e LEFÈVRE (2003) é o de que o sujeito coletivo se revela através de um eu (primeira pessoa coletiva - do singular), que expressa a presença de um sujeito individual do discurso e, ao mesmo tempo, contém uma referência coletiva, na medida em que esse eu fala pela ou em nome de uma coletividade. Para os autores o pensamento deste grupo de pessoas 
pode ser visto como o conjunto dos discursos ou formações

discursivas, ou representações sociais, existentes nas circunstâncias em que foram produzidos. Neste trabalho, conforme detalhamos anteriormente, o contexto determinado e específico no qual ocorreu nossa experiência é contemplado.

Muito embora, no presente caso, o interesse esteja centrado nos aspectos mais significativos e recorrentes dos discursos sobre a avaliação da experiência, sem pressupor generalização, a idéia básica é a de que tais conteúdos, devido à peculiaridade dos sujeitos, possam vir a ocorrer de maneira semelhante em outros grupos de residentes que passem pelo mesmo tipo de experiência de ensino. Isto porque trata-se de uma categoria relativamente homogênea médicos residentes - que apresenta características próprias.

\subsection{Figuras metodológicas}

Para construirmos os discursos dos sujeitos coletivos, recorremos as seguintes figuras metodológicas:

6.4.1. Expressões-chave (ECH): compostas pela transcrição literal do discurso que expressa a essência do depoimento. Elas representam o conteúdo ou o sentido dos discursos. Segundo LEFÈVRE e LEFÉVRE (2003), elas servem como matéria prima para a construção dos discursos do sujeito coletivo. O conjunto das avaliações, na sua literalidade encontra-se em anexo, para consulta, se necessário.

6.4.2. Idéia centrais (IC): busca descrever da maneira mais sintética e fidedigna possível o sentido de cada depoimento analisado 
e de cada conjunto homogêneo de $\mathrm{ECH}$. Sua função consiste em individualizar um dado discurso, ao descrever e distinguir suas especificidades semânticas. Ela é uma espécie de nome ou marca do sentido dos discursos.

6.4.3. Discurso do sujeito coletivo (DSC): é o discurso-síntese redigido na primeira pessoa do singular e composto pelas $\mathrm{ECH}$ que têm a mesma IC. Vale notar que a proposta do DSC procura reconstruir, a partir dos fragmentos individuais, tantos discursossíntese quantos forem necessários para dar conta de uma determinada representação social sobre um fenômeno. Trata-se, portanto, de uma estratégia metodológica que ao utilizar um expediente discursivo, busca tornar mais clara e explicitada uma dada representação social ou mesmo um conjunto das representações. Para elaborar o DSC, parte-se do material em estado bruto, submetido ao trabalho analítico de decomposição (seleção das principais IC presentes em cada depoimento e em todos eles reunidos) que posteriormente, recebe uma forma sintética ao chegarmos em uma reconstituição discursiva de determinada representação social, que se expressa por idéias centrais apresentadas como categorias empíricas.

\subsection{Processo de construção dos discursos-síntese}

O trabalho referente ao tratamento dos dados pode ser apresentado como um longo processo de construção, realizado em várias etapas.

Inicialmente, a leitura e a releitura das avaliações dos residentes foram feitas com o intuito de estabelecer uma certa familiaridade com o material. Em seguida, as avaliações foram 
digitadas, na seqüência em que foram realizadas, em uma tabela, em anexo, e posteriormente procedeu-se ao trabalho de identificação das idéias centrais, de caráter provisório e seus desdobramentos, de forma que o próprio material pudesse revelar estes elementos. Neste momento, a intenção foi a de traduzir as expressões-chave em idéias centrais.

A etapa seguinte consistiu em reler todo o material e listar todas as idéias centrais identificadas a partir das correspondentes expressões-chave. Foi possível perceber uma certa repetição ou redundância, por exemplo, a mesma idéia central estava escrita de forma diferente, de tal forma que se buscou sintetizar melhor, em termos de distingüir o essencial dos detalhes. Finalmente, a análise mais acurada do que se encontrou em termos de idéias centrais nos sugeriu a possibilidade da subdivisão em grandes temas ou núcleos estruturadores do discurso, que poderiam organizar melhor nosso trabalho posterior de discussão de dados.

Apresentaremos, portanto, estes temas ou núcleos, e, para cada um deles as idéias centrais, as expressões-chave e o discurso do sujeito coletivo ou discurso-síntese correpondente. Fica evidenciado, tanto o trabalho de recorte das expressões-chave que pode ser consultado na tabela em anexo, como o procedimento para a construção do discurso do sujeito coletivo que sustentará a etapa seguinte, que é a da análise e discussão.

\subsection{Aspectos éticos}

Considerando que o material escolhido, em nossa pesquisa, refere-se a textos produzidos em contexto de ensino, esclarecemos que os alunos foram informados que a avaliação realizada seria submetida à análise pela pesquisadora. Os residentes que 
entregaram as avaliações no ano de 2003 foram posteriormente procurados e convidados a assinar o termo de consentimento esclarecido, no ano de 2004, cujo modelo encontra-se em anexo.

Cumpre observar que foram mantidos "a confidencialidade, a privacidade, a proteção de imagem e a não estigmatização, garantindo a não utilização das informações em prejuízo das pessoas", conforme Resolução 196/1996, que regulamenta pesquisas envolvendo seres humanos.

Trata-se de pesquisa, cujo objetivo central, só poderia ser alcançado através da participação efetiva dos sujeitos envolvidos. Assim, o meio que escolhemos para realizá-lo se justifica, na medida em que visamos garantir o retorno dos benefícios obtidos, através desta investigação, para a instituição na qual ela foi realizada. 


\section{Descrição e análise dos resultados}

\subsection{Caracterização dos discursos-síntese dos sujeitos produtores da avaliação}

A caracterização dos discursos-síntese é apresentada no contexto de cinco grandes temas que foram identificados como núcleos estruturadores do presente trabalho. São eles: avaliação geral, avaliação do conteúdo, avaliação da dinâmica e metodologias empregadas, avaliação da coordenação e sugestões.

A seguir, cada um deles é apresentado, identificando as respectivas idéias centrais neles contidos, assim como as correspondentes expressões-chave que os sustentam.

\section{TEMA 1: AVALIAÇÃO GERAL}

Idéia central 1 - O curso apresenta uma proposta inusitada e não convencional.

Idéia central 2 - Gostei muito do estágio / O curso foi excelente.

Idéia central 3 - O curso apresenta uma proposta sobre temas de extrema relevância que não são aprofundados durante a graduação e a residência.

Idéia central 4 - O curso proporciona uma abertura para mudanças e questionamentos.

Idéia central 5 - O curso foi marcante para minha formação e para a prática pediátrica.

Idéia central 6 - O curso contribui para ampliar a visão da Pediatria, identificar e atuar sobre os aspectos psíquicos do paciente, para além do orgânico. 
Idéia central 7 - O curso fornece elementos tanto para a prática clínica como para discussões em outras atividades.

Idéia central 8 - O curso é necessário e está bem colocado no programa de residência.

Idéia central 9 - O curso permite conhecer melhor a nós mesmos.

Idéia central 10 - As férias, durante o curso, prejudica bastante o aprendizado dos conceitos, pois há uma lógica entre eles.

\section{IDÉIA CENTRAL 1 - O curso apresenta uma proposta inusitada e não convencional.}

EXPRESSÕES-CHAVE UTILIZADAS:

R1 - "Tinha uma idéia diferente do curso, antes do seu início. Acreditava que a abordagem dos temas seria pautada pelos casos recebidos no CS-E. Confesso que tive uma surpresa bastante agradável com a proposta apresentada."

R38 - "De início, pensei se tratar de curso teórico, onde aprenderíamos técnicas "psi" para lidar com diversos assuntos (violência, adoção, papéis materno e paterno...) muito comuns na prática pediátrica. Percebi, no entanto, que se tratava de coisa muito diferente de um "manual" de assuntos psicológicos/psiquiátricos. Surgia a oportunidade de ler textos, algumas vezes controversos, muitas vezes também extremamente subjetivos, mas que colocavam devidamente os assuntos em pauta. E as mais variadas opiniões e observações sobre os temas em questão apareciam."

R39 - "Considero este curso algo peculiar, numa formação tão tecnicista e impessoal."

R44 - "Eles me ajudaram a enxergar a Pediatria sob um prisma diferente, trabalhando questões "novas" e de uma forma não-habitual." 


\section{DSC1}

"Tinha uma idéia diferente do curso, antes do seu início. Acreditava que a abordagem dos temas seria pautada pelos casos recebidos no CS-E, ou talvez, de um curso teórico, onde aprenderíamos técnicas "psi" para lidar com diversos assuntos (violência, adoção, papéis materno e paterno...) muito comuns na prática pediátrica. Percebi, no entanto, que se tratava de coisa muito diferente de um "manual" de assuntos psicológicos/psiquiátricos. Surgia a oportunidade de ler textos, algumas vezes controversos, muitas vezes também extremamente subjetivos, mas que colocavam devidamente os assuntos em pauta. Eles me ajudaram a enxergar a Pediatria sob um prisma diferente, trabalhando questões "novas" e de uma forma nãohabitual. E as mais variadas opiniões e observações sobre os temas em questão apareciam. Confesso que tive uma surpresa bastante agradável com a proposta apresentada. Considero este curso algo peculiar, numa formação tão tecnicista e impessoal."

\section{IDÉIA CENTRAL 2: 0 curso foi excelente, gostei muito do estágio}

EXPRESSÕES-CHAVE UTILIZADAS:

R3 - "Em minha opinião, o curso de Saúde Mental, como parte do estágio em Pediatria Comunitária, foi excelente. Gostei muito dos textos propostos, mas principalmente das discussões."

R15 - "Gostei muito, nos permitiu aprender mais sobre temas comumente enfrentados em nosso ambulatório didático e com um enfoque distinto da Psiquiatria."

R23 - "Adorei o estágio!!"

R25 - "Gostei bastante do curso."

R29 - "Apesar de sucinta, minha avaliação do estágio e de nossas discussões é excelente, gostaria de tê-la realizado no início do ano." 
R38 - "De uma maneira bem simplista, poderia dizer que gostei bastante e acho que aproveitei o que podia."

R44 - "Realmente gostei muito dos nossos encontros sobre saúde mental."

R45 - "Enfim, gostei muito deste estágio, embora acho que não aproveitei $100 \%$, devido aos meus vários plantões de quinta à noite."

R50 - "Gostei muito do estágio."

R53 - "Eu, sinceramente, gostei muito do curso de Saúde Mental."

\section{DSC2}

"Em minha opinião, o curso de Saúde Mental, como parte do estágio em Pediatria Comunitária, foi excelente. Gostei muito dos textos propostos, mas principalmente das discussões, que nos permitiu aprender mais sobre temas comumente enfrentados em nosso ambulatório didático e com um enfoque distinto da Psiquiatria. Acho que aproveitei o que podia e gostaria de tê-lo realizado no início do ano."

IDÉIA CENTRAL 3: O curso apresenta uma proposta sobre temas de extrema relevância que não são aprofundados durante a graduação e a residência.

\section{EXPRESSÕES-CHAVE UTILIZADAS:}

R1 - "É uma excelente oportunidade para sairmos do "academicismo" a que já estamos acostumados e discutirmos temas que, infelizmente, não teremos muita chance de fazê-lo ao longo da residência. Ou melhor, talvez os temas possam ressurgir, mas não serão vastamente explorados, nem usarão literatura adequada para nortear as discussões."

R5 - "Considero de grande importância os seminários sobre o desenvolvimento da personalidade da criança, pois são levantados aspectos que, normalmente, não são bem abordados, apesar da extrema relevância." 
R28 - "As discussões das sextas-feiras foram muito interessantes, já que pudemos refletir sobre assuntos relevantes e que, às vezes, devido à correria do dia-a-dia eram vistos como secundários."

R29 -" Mesmo com nossa ignorância parcial frente à Psicanálise, as discussões e debates permitiram um ótima introdução sobre o tema, muito pouco abordado na nossa residência."

R31 - "Acho que este curso dado durante a residência, é de importância capital, principalmente porque é um campo não muito aprofundado durante a graduação."

R34 - "O estágio foi interessante no sentido de discutirmos temas importantes e pouco abordados na graduação e na residência médica."

R38 - "Muitos dos temas, pelo menos para mim, nunca haviam sido abordados durante a graduação (p.ex., o suicídio na infância e adolescência, fato que me chocou de certa forma) e contribuíram para aumentar a minha visão do ser biopsicossocial (esse sim, tão falado na faculdade, mas tão pouco abordado, de fato)."

R39 - "Na minha opinião, muitos aspectos podem ser apontados sobre este curso. Foi muito interessante entrar em contato com outro profissional da saúde da criança que tivesse uma formação não-médica. Deste contato, pudemos conhecer outros modos de interpretação dos problemas comuns que encontramos na clínica pediátrica e que, infelizmente, não são muito valorizados na nossa formação acadêmica, que acaba sendo muito técnica e, paradoxalmente, pouco humanizada."

R40 - "Quando recebi a programação das aulas achei os temas bem interessantes e bem amplos, onde teríamos oportunidades para entender e discutir sobre questões que como pediatra geralmente não temos acesso e nem base para enfrentar, como situações novas de família: pais homossexuais, pais sozinhos que cuidam dos filhos, pai que faz papel de mãe e vice-versa. Outros temas interessantes foram: criança e mídia, adoção, violência, depressão, relação médico-paciente."

R42 - "Creio que fizeram com que pensássemos em tópicos que não veríamos nos módulos convencionais da residência."

R45 - "O curso de saúde mental foi uma experiência nova para mim. A oportunidade de debater temas como a estruturação da família, violência, 
adoção etc, no curso de residência foi uma surpresa, já que nossa formação está mais direcionada para as patologias puramente "orgânicas". Como pude concluir no decorrer do curso, esses temas são importantíssimos, pois a consulta pediátrica envolve muito a parte psicossocial da criança."

R47 - "Os temas abordados são temas muito pertinentes ao nosso dia-a-dia, são problemas que nos deparamos todos os dias em nosso trabalho. E o interessante é que muitas vezes não paramos para pensar ou refletir."

R48 - "A atividade, ao meu ver, atingiu sua proposta de discutir e pensar em temas atuais e importantes da saúde mental da criança. Trabalhou a avaliação da criança como um todo, soma de si mesma e do meio que a cerca. Abordou temas difíceis, polêmicos e atuais como depressão, violência, mídia, fracasso, escolar, adoção; temas importantes e presentes nas nossas atividades práticas ambulatoriais e muitas vezes não abordados por serem difíceis, por falta de conhecimento sobre o assunto, pela sensação de não-resolutividade - quando, na verdade, nosso papel muitas vezes será apenas de esclarecer e orientar, muita pretensão querer resolver o problema de todos."

R50 - "Em conjunto com outros estágios do Centro de Saúde, esse estágio contribuiu para pensarmos sobre assuntos que têm importância social. Para mim foi super-importante, sinceramente, não esperava encontrar essa preocupação numa residência que de acordo com meus préconceitos, seguiria um padrão mais tradicional, simplificando o paciente a uma doença e não a uma pessoa como ele deve ser visto."

R51 - "O módulo de Saúde Mental, dentro do ensino da Pediatria Comunitária, foi realmente muito proveitoso. Pudemos discutir temas de grande importância e muitas vezes presentes em nossas vidas ou na prática clínica, mas que em geral são vistos sob outros ângulos."

R56 - "As atividades de sexta-feira do estágio da Pediatria Comunitária, com abordagem de temas relacionados ao psiquismo da criança e de como lidar com os aspectos da subjetividade da criança são de grande valia para nós, residentes, já que não temos tal abordagem em nenhum outro segmento da residência e sabe-se que o desenvolvimento da 
criança está intimamente relacionado com a preservação de seu psicoemocional em condições adequadas."

R57 - "Achei muito válido o contato que tivemos com a Psicologia infantil, pois não temos uma atenção específica do assunto no nosso dia-adia na residência."

R58 - "A integração da Psicologia com o aprendizado na Pediatria é muito importante e necessário. Podemos comentar sobre vários assuntos que nem sempre são lembrados ou discutidos no nosso dia-a-dia."

\section{DSC3}

"As discussões das sextas-feiras foram muito interessantes, já que pudemos refletir sobre assuntos relevantes e que foram pouco abordados na graduação e na residência médica. Foi muito interessante entrar em contato com outro profissional da saúde da criança que tivesse uma formação não-médica. Deste contato, pudemos conhecer outros modos de interpretação dos problemas comuns que encontramos na clínica pediátrica e que, infelizmente, não são muito valorizados na nossa formação acadêmica, que acaba sendo muito técnica e, paradoxalmente, pouco humanizada. A abordagem de temas relacionados ao psiquismo da criança e de como lidar com os aspectos da subjetividade da criança são de grande valia para nós, residentes, já que não temos tal abordagem em nenhum outro segmento da nossa formação e sabe-se que o desenvolvimento da criança está intimamente relacionado com a preservação de seu psico-emocional em condições adequadas. Muitos dos temas, pelo menos para mim, nunca haviam sido abordados durante a graduação, tivemos a oportunidade para entender e discutir sobre questões que como pediatra não temos acesso e nem base para enfrentar, como situações novas de família: pais homossexuais, pais sozinhos que cuidam dos filhos, pai que faz papel de mãe e vice-versa, criança e mídia, adoção, violência, depressão, relação médico-paciente, o suicídio na infância e adolescência (fato que me chocou de certa forma). Estas discussões contribuíram para aumentar a minha visão do ser biopsicossocial (esse sim, tão falado na faculdade, mas tão 
pouco abordado, de fato) e a oportunidade de debate no curso de residência foi uma surpresa, já que nossa formação está mais direcionada para as patologias puramente "orgânicas". Como pude concluir no decorrer do curso, esses temas são importantíssimos, pois a consulta pediátrica envolve muito a parte psicossocial da criança. Acho que estes temas, importantes e presentes nas nossas atividades práticas ambulatoriais, muitas vezes não são abordados por serem difíceis, por falta de conhecimento sobre o assunto, pela sensação de não-resolutividade - porém, na verdade, nosso papel muitas vezes será apenas de esclarecer e orientar, muita pretensão querer resolver o problema de todos."

IDÉIA CENTRAL 4: O curso proporciona uma abertura para mudanças e questionamentos.

\section{EXPRESSÕES-CHAVE UTILIZADAS:}

R6 - "Acredito que na primeira sexta-feira do estágio se iniciou um processo que não cessará com o final do estágio, afinal muitas questões foram despertadas, pontos de vista foram mudados, passamos a enxergar, por exemplo, que junto com um bebê que cresce, se desenvolve também um sujeito."

R45 - "Um outro aspecto foi entrar em contato com textos de outras áreas como Psicologia/Psicanálise, muitas vezes textos difíceis de serem lidos. Porém, acho interessante poder entrar em contato com esses textos que nos "abrem horizontes", pois não o faria espontaneamente."

R46 - "Achei o curso de saúde mental muito proveitoso. Foi uma das atividades do estágio de Pediatria Comunitária que abriu a cabeça, jogou conceitos velhos fora e fez agente realmente pensar (o que falta um pouco nos outros estágios da residência)." 
R52 - "As discussões foram enriquecedoras, me fizeram recordar os tempos em que fazia análise - alguns minutos para refletir. Levantamos questões que me suscitaram sentimentos e lembranças, esquecidas com a correria da residência."

R53 - "Acho que os temas selecionados foram muito bons pois nos abriram campo para discussões bastante interessantes. Certamente, não termino o curso dominando nenhum destes assuntos, mas saio com interesse em estudar sobre todos eles. Saiba que despertar meu interesse sobre assuntos "psi" foi um feito inédito. Obrigada."

\section{DSC4}

"Acredito que na primeira sexta-feira do estágio se iniciou um processo que não cessará com o final do estágio, afinal muitas questões foram despertadas, pontos de vista foram mudados, os temas selecionados foram muito bons pois nos abriram campo para discussões bastante interessantes. Um outro aspecto foi entrar em contato com textos de outras áreas como Psicologia/Psicanálise, muitas vezes textos difíceis de serem lidos. Porém, acho interessante poder entrar em contato com esses textos que nos "abrem horizontes", pois não o faria espontaneamente. As discussões foram enriquecedoras, passamos a enxergar, por exemplo, que junto com um bebê que cresce, se desenvolve também um sujeito. O curso de saúde mental foi muito proveitoso, pois fez a gente realmente pensar (o que falta um pouco nos outros estágios da residência). Certamente, não termino o curso dominando nenhum dos assuntos, mas saio com interesse em estudar sobre todos eles. Saiba que despertar meu interesse sobre assuntos "psi" foi um feito inédito."

IDÉIA CENTRAL 5: O curso foi marcante para minha formação e para a prática pediátrica. 


\section{EXPRESSÕES-CHAVE UTILIZADAS:}

R6 - "Aprendemos muito, certamente este foi um momento bastante marcante de nossa formação e continuaremos colhendo os frutos, ao longo de nossa vida profissional e pessoal."

R16 - "Aprendi muito no curso e creio estar agora com olhos e ouvidos mais atentos para os aspectos da relação mãe-filho e do desenvolvimento emocional da criança."

R26 - "O curso de sexta-feira foi importante para minha formação como médica pois pôde me fazer compreender melhor a relação com meus pacientes. Através da leitura dos textos e das discussões em grupo, foi possível entender melhor meus sentimentos em relação ao paciente e como posso tentar melhorar o vínculo com alguns deles. Além disso, me fez entender porque alguns pacientes e a família têm determinados comportamentos."

R28 - "Achei esse estágio importante para minha formação de médica, já que foi o único espaço da residência reservado para discussões de questões éticas e psicossociais."

R43 - "Em minha opinião o curso de saúde mental da criança teve grande importância em minha formação e, com certeza, influenciará em minha prática pediátrica futura. Discutimos assuntos que envolvem toda a vida e a história da criança. A criança é um ser em desenvolvimento físico, mental, emocional, social etc e está sujeito a influências do meio. Por isso, é necessário conhecer e avaliar tudo o que envolve a vida da criança, o contexto familiar no qual essa criança está inserida, sua vida social, seus contatos, suas atividades diárias e como ela é capaz de lidar com situações novas e, às vezes, hostis. Todos os profissionais que trabalham com crianças, incluindo o pediatra, devem conhecer as diversas formas e, talvez, sintomas que as crianças se utilizam para expressar seus sentimentos, suas angústias, seus medos, suas alegrias, seus gritos de ajuda ou independência. A criança é um indivíduo que está formando sua personalidade e tudo o que acontecer em sua vida ou ao seu redor neste período, ajudará consciente ou inconscientemente, positiva ou 
negativamente, na formação de sua personalidade. Desta forma, acredito que este curso me ajudou a entender um pouco do que influencia a vida da criança e de como a criança pode expressar essas influências."

\section{DSC5}

"Aprendi muito, certamente este foi um momento bastante marcante de minha formação e continuarei colhendo os frutos, ao longo de minha vida profissional e pessoal. Creio estar agora com olhos e ouvidos mais atentos para os aspectos da relação mãe-filho e do desenvolvimento emocional da criança. Foi possível, também, entender melhor meus sentimentos em relação ao paciente e como posso tentar melhorar o vínculo com alguns deles. Além disso, me fez entender porque alguns pacientes e suas famílias têm determinados comportamentos. Interessante notar que foi o único espaço da residência reservado para discussões de questões éticas e psicossociais da criança. A criança é um ser em desenvolvimento físico, mental, emocional, social etc e está sujeito a influências do meio. Por isso, é necessário conhecer e avaliar tudo o que envolve a vida da criança, o contexto familiar no qual essa criança está inserida, sua vida social, seus contatos, suas atividades diárias e como ela é capaz de lidar com situações novas e, às vezes, hostis. A criança é um indivíduo que está formando sua personalidade e tudo o que acontecer em sua vida ou ao seu redor neste período, ajudará consciente ou inconscientemente, positiva ou negativamente, na formação de sua personalidade. Desta forma, acredito que este curso me ajudou a entender um pouco do que influencia a vida da criança e de como a criança pode expressar essas influências." 


\title{
IDÉIA CENTRAL 6: 0 curso contribui para ampliar a visão da Pediatria, identificar e atuar sobre os aspectos psíquicos do paciente, para além do orgânico.
}

\author{
EXPRESSÕES-CHAVE UTILIZADAS:
}

R10 - "Acho interessante que a residência de Pediatria nos ofereça a oportunidade de pensar o paciente também como sujeito de emoções e essência psíquica, compreendendo que o equilíbrio entre saúde e doença tem aspectos que não são puramente orgânicos."

R23 - "Acho importante que o médico seja capaz de enxergar mais que somente um corpo humano, mas também o "ser" - com todas suas neuroses - que a ele dá vida. Além de nos ampliar a visão em relação ao paciente, os temas abordados, nos permitiram avaliar um pouco as possíveis interações da criança com o meio, em diversos sentidos. Como a criança é vista atualmente pela sociedade? Que papel ela exerce? A que distúrbios psicológicos ela está submetida? Quais são as aspirações da juventude de hoje? Entre outras questões..."

R27 - "Gostei muito deste estágio, foi uma oportunidade única na residência de ter contato com a higiene mental e com outros profissionais de saúde, não-médicos, que permitiram uma outra visão dos temas abordados."

R37 - "Sem dúvida, o estágio foi muito proveitoso e para mim atingiu o objetivo de tentar identificar as famílias e crianças que poderiam se beneficiar com uma atuação não somente "patológica ou orgânica" de minha parte ou até com o encaminhamento para um profissional mais habilitado que eu nessa área."

R38 - "O curso, como um todo, apesar do cansaço dos pós-plantões (perdoe nossas "pescadas" durante o período), contribuiu em muito para ampliar a visão na pediatria geral, abrir oportunidades de avaliar coisas além do "peso-altura-mamadeira-cocô-queixas orgânicas" e nos incentivou a buscar coisas além da chamada "consulta de rotina", como a relação entre os pais e destes com seus filhos, os papéis desempenhados em casa, a abordagem da violência doméstica, dentre outros." 
R41 - "Há muito já se reconheceu a relevância da Psicologia na compreensão e no tratamento de enfermidades orgânicas que desencadeiam doenças mentais. Mas a nova Pediatria, particularmente, está dando enfoque aos aspectos do desenvolvimento psíquico infantil e a relação com a doença. A união da Pediatria à Psicologia é perfeita pela necessidade de se ter uma visão holística do ser humano. Por mais que as especialidades da Medicina sejam relevantes, os especialistas atuais não devem se afastar da situação global do indivíduo. Perceber o paciente em toda a sua dimensão é o que existe de mais moderno, sensato e humano nos dias de hoje."

R54 - "O estágio apresentado para a residêndia de Pediatria ofereceu a oportunidade de discutir pelo menos alguns tópicos que estão presentes na sociedade contemporânea e geralmente não são abordados em um anamnese, às vezes até por desconhecimento. O período é curto e com certeza, há muito mais tópicos que deveriam estar sendo abordados, mas pelo menos tivemos a oportunidade de reconhecer a importância e discuti-los, o que espero que possa voltar o olhar clínico do médico recémformado além das questões puramente físicas."

R57 - "A minha opinião é que a consulta não pode e não deve se restringir somente à queixa orgânica, por vários motivos. Primeiro porque essa queixa, conscientemente ou não, leva a uma angústia/dúvida/medo, tanto para a família, como às vezes, para a própria criança. Segundo que pode haver relação de causa e efeito entre a queixa e o aspecto psicológico. Por isso, ter a oportunidade de poder discutir sobre o assunto é de extrema importância para a formação de um profissional completo."

\section{DSC6}

"O curso contribuiu muito para ampliar a visão da Pediatria geral, abrir oportunidades de avaliar tópicos que estão presentes na sociedade contemporânea, que não são abordados em um anamnese e, portanto, ir além do "peso-altura-mamadeira-cocô-queixas orgânicas". Como, por exemplo, a relação entre os pais e destes com seus filhos, os papéis desempenhados em casa, a abordagem da violência doméstica. Na minha opinião, a consulta não pode e não 
deve se restringir somente à queixa orgânica, por vários motivos. Primeiro, porque essa queixa, conscientemente ou não, leva a uma angústia/dúvida/medo, tanto para a família, como às vezes, para a própria criança. Segundo, porque pode haver relação de causa e efeito entre a queixa e o aspecto psicológico. Por isso, ter a oportunidade de discutir sobre o assunto é de extrema importância para a formação de um profissional completo. Além de nos ampliar a visão em relação ao paciente, os temas abordados, nos permitiram avaliar um pouco as possíveis interações da criança com o meio, em diversos sentidos. Como a criança é vista atualmente pela sociedade? Que papel ela exerce? A que distúrbios psicológicos ela está submetida? Quais são as aspirações da juventude de hoje? A união da Pediatria à Psicologia é perfeita pela necessidade de se ter uma visão holística do ser humano. Por mais que as especialidades da Medicina sejam relevantes, os especialistas atuais não devem se afastar da situação global do indivíduo. Perceber o paciente em toda a sua dimensão é o que existe de mais moderno, sensato e humano nos dias de hoje."

\section{IDÉIA CENTRAL 7: 0 curso fornece elementos tanto para a prática clínica como para discussões em outras atividades.}

\section{EXPRESSÕES-CHAVE UTILIZADAS:}

R10 - "O curso se destaca por tentar mostrar a realidade em que estão inseridas as crianças, sua família, o conceito e formação histórica do núcleo familiar. Tudo isso mostra um detalhamento e uma riqueza que, se bem explorado na prática clínica, pode dar pistas importantes para o melhor acompanhamento do paciente."

R12 - "Os temas abordados foram interessantes e atuais, e pudemos aproveitá-los em outros momentos (como por exemplo, em algumas aulas do Ambulatório do HU e mesmo no Posto de Saúde, durante as discussões 
sobre desenvolvimento, nos estágios da creche e nas discussões realizadas às quintas-feiras)."

R13 - "Em certos casos que vejo no ambulatório, deu para entender melhor a dinâmica familiar e até conhecer melhor o "sujeito"."

R14 - "Achei os temas abordados pertinentes, as discussões muito boas, ricas e produtivas, sustentadas por textos diferentes do habitual de leitura médica, uma abordagem diferente e muito válida, trouxe-me elementos úteis para minha prática médica (e não só médica, para a vida!)"

R15 - "Gostei muito, nos permitiu aprender mais sobre temas comumente enfrentados em nosso ambulatório didático e com um enfoque distinto da Psiquiatria."

R17 - "Nossas discussões ampliaram a visão dos fatores que estão envolvidos nestas queixas. Elas também deram suporte para buscarmos respostas e compreensão das dificuldades que envolvem a relação pais e filhos e até mesmo para nos prepararmos como futuros pais e mães."

R22 - "Foi bom abordar queixas tão freqüentes no dia-a-dia dos ambulatórios, pronto-socorro, numa visão um pouco mais profunda, menos imediatista e menos "causa-efeito."

R55 - "Refletir sobre os temas que discutimos fortaleceu minha maneira de ver o paciente e de lidar com as diversas situações nas quais ele está inserido. Mas meu maior ganho mesmo foi perceber que cada vez mais a Medicina tem trazido para si a valorização do paciente como um ser único, como um indivíduo completo e que criar vínculos verdadeiros, preocupar-se, solidarizar-se, alegrar-se e até sofrer com e pelo paciente, não significa "ser mole" e sim exercer uma Medicina com muito mais sentido."

R56 - "Além disso, abre-se um espaço para que nós possamos trazer à discussão angústias, dúvidas de casos que atendemos no PA ou em outro serviço, principalmente relacionados com dificuldades na relação com pacientes (ou mais comumente com suas mães), assistentes, colegas; além da discussão de casos que apresentam distúrbios psicológicos ou emocionais, assim como dificuldade escolar, de linguagem , fala e outras."

\section{DSC7}


"O curso se destaca por tentar mostrar a realidade em que estão inseridas as crianças, sua família, o conceito e a formação histórica do núcleo familiar. Tudo isso mostra um detalhamento e uma riqueza que, se bem explorado na prática clínica, pode dar pistas importantes para o melhor acompanhamento do paciente. Em certos casos que vejo no ambulatório, deu para entender melhor a dinâmica familiar e até conhecer melhor o "sujeito". Nossas discussões ampliaram a visão dos fatores que estão envolvidos nas queixas trazidas, de maneira um pouco mais profunda, menos imediatista e menos "causa-efeito". Elas também deram suporte para buscarmos respostas e compreensão das dificuldades que envolvem a relação entre pais e filhos e até mesmo para nos prepararmos como futuros pais e mães. Foi possível aproveitar os temas em outros momentos, como por exemplo, em algumas aulas do Ambulatório do $\mathrm{HU}$ e mesmo no Posto de Saúde, durante as discussões sobre desenvolvimento, nos estágios da creche e nas discussões realizadas às quintas-feiras. Mas meu maior ganho mesmo foi perceber que cada vez mais a Medicina tem trazido para si a valorização do paciente como um ser único, como um indivíduo completo e que criar vínculos verdadeiros, preocupar-se, solidarizar-se, alegrar-se e até sofrer com e pelo paciente significa exercer uma Medicina com muito mais sentido. Enfim, trouxe-me elementos úteis para minha prática médica e para a vida!"

\section{IDÉIA CENTRAL 8: O curso é necessário e está bem colocado no programa de residência.}

\section{EXPRESSÕES-CHAVE UTILIZADAS:}

R10 - "Em suma, um curso interessante e bem colocado no R1, época em que estamos compreendendo a criança da forma mais generalista." 
R38 - " O curso foi bem inserido durante o módulo de Pediatria Comunitária, onde a clientela atendida (na maioria moradores da favela próxima) nos ilustrava as várias questões abordadas."

R47 - "Esse estágio é extremamente necessário em nosso programa de residência, pois a residência é vivida em um ambiente estressante, em que somos considerados uma mão-de-obra para "tocar o serviço" onde se desenvolve muito a ciência e se esquece um pouco o lado humano, que por trás do residente existe um ser como qualquer ser humano com medos e angústias e que está disposto a resolver o problema de seu paciente que vem te procurar na maioria das vezes, fragilizado, inseguro e temendo sobre alguma desarmonia biopsicossocial."

\section{DSC8}

"O curso está bem colocado no primeiro ano da residência, época em que estamos compreendendo a criança de forma mais generalista, e foi bem inserido durante o módulo de Pediatria Comunitária, onde a clientela atendida (na maioria, moradores da favela próxima) nos ilustrava as várias questões abordadas. Este curso é extremamente necessário em nosso programa de residência, pois esta é vivida em um ambiente estressante, em que somos considerados uma mão-deobra para "tocar o serviço" onde se desenvolve muito a ciência e se esquece um pouco o lado humano. É importante lembrar, também, que por trás do residente existe um ser humano, como qualquer outro, com medos e angústias e que está disposto a resolver o problema de seu paciente e este, por sua vez, ao procurar o médico, na maioria das vezes, vem fragilizado, inseguro e temendo sobre alguma desarmonia biopsicossocial."

\section{IDÉIA CENTRAL 9: 0 curso permite conhecer melhor a nós mesmos.}

EXPRESSÕES-CHAVE UTILIZADAS: 
R20 - "É gratificante poder ter um momento nessa vida corrida que é a Medicina (Pediatria, em especial) para sentar e conversar sobre assuntos muito pertinentes em nossa vivência diária. Mais do que entender melhor as relações entre os nossos pacientes, seus pais e o meio que os cercam, o curso nos permitiu conhecer melhor a nós mesmos: cada um em separado e o grupo como um todo. Os benefícios serão levados para o resto da residência e, mais importante, para nossas vidas. Obrigada!"

R49 - "Mesmo assim, tive um ganho imenso, não só em relação ao meu auto-conhecimento, que enxergo agora como fundamental para aprimorar minha relação interpessoal, tanto na minha vida particular, como principalmente, na minha vida profissional. Vejo agora que meu bem-estar é indispensável na tentativa de estabelecer qualquer vínculo com meus pacientes e seus responsáveis, desde a relação mais curta, como numa consulta de pronto-socorro, até o maior vínculo, necessário para um bom acompanhamento ambulatorial."

R55 - "Uma das perguntas que surgiram nesta ocasião, foi de onde surgira a idéia de cada um partir para a área médica e, o que de início parecia apenas mais uma das centenas de vezes que descreveríamos nossos motivos e vocações, foi na verdade, um momento de profundas revelações tanto a respeito dos meus colegas como (para minha surpresa) sobre mim mesma."

\section{DSC9}

"É gratificante ter um momento nessa vida corrida que é a Medicina (Pediatria, em especial) para sentar e conversar sobre assuntos muito pertinentes em nossa vivência diária. Mais do que entender melhor as relações entre os nossos pacientes, seus pais e o meio que os cercam, o curso nos permitiu conhecer melhor a nós mesmos: cada um em separado e o grupo como um todo. Em uma das atividades em que se perguntou de onde surgira a idéia de cada um partir para a área médica e, o que parecia apenas mais uma das centenas de vezes que descreveríamos nossos motivos e vocações, foi na verdade, um momento de profundas revelações, tanto a respeito dos meus colegas como (para minha surpresa) sobre mim mesma. Vejo 
agora que meu bem-estar é indispensável na tentativa de estabelecer qualquer vínculo com meus pacientes e seus responsáveis, desde a relação mais curta, como numa consulta de pronto-socorro, até o maior vínculo, necessário para um bom acompanhamento ambulatorial. Os benefícios serão levados para o resto da residência e, mais importante, para nossas vidas."

\section{IDÉIA CENTRAL 10: As férias, durante o curso, prejudica bastante o aprendizado dos conceitos, pois há uma lógica na seqüência dos temas.}

\section{EXPRESSÕES-CHAVE UTILIZADAS:}

R3 - "Infelizmente, perdi 3 discussões, motivado pelas minhas férias e, assim, não participei da discussão de "Pacto edípico e pacto social", do que me ressinto muito, pois trazia muitos conceitos e conhecimentos que eu não tinha. Assim que voltei das férias, senti bastante a falta de alguns conceitos que tinham sido trabalhados naqueles dias, principalmente sobre o desenvolvimento da subjetividade, pois muito se falou sobre isso na semana que se seguiu e até agora estou tentando recuperar esta perda."

R40 - "Infelizmente, muitos de nós somos obrigados a tirar férias durante o estágio de Pediatria Comunitária e saímos perdendo, pois ambulatório, enfermaria, PS, sempre é possível repor e essas discussões são únicas nesta fase de nossa formação."

R42 - "Acabei perdendo 3 temas por causa das férias e sugiro que haja um meio de que isso não ocorra nas outras turmas, pois acabamos perdendo a metade do programa."

\section{DSC10}

"Infelizmente, muitos de nós somos obrigados a tirar férias durante o estágio de Pediatria Comunitária e saímos perdendo, pois essas discussões são únicas nesta fase de nossa formação, diferentemente de ambulatório, enfermaria e PS, onde é possível a reposição. Acabei 
perdendo 3 temas por causa das férias, quando voltei, senti bastante a falta de alguns conceitos que tinham sido trabalhados naqueles dias, principalmente sobre o desenvolvimento da subjetividade, pois muito se falou sobre isso nas semanas que se seguiram e até agora estou tentando recuperar esta perda. Sugiro que haja um meio de que isso não ocorra nas outras turmas, pois acabamos perdendo uma boa parte do programa."

\section{TEMA 2: AVALIAÇÃO DO CONTEÚDO}

Idéia central 1: Os textos são difíceis, no início, mas necessários para dar sustentação às discussões, que se tornam mais claras com a evolução do curso.

Idéia central 2: Os textos utilizados são pertinentes aos temas e suscitam questionamentos, reflexões e críticas.

Idéia central 3: Meu conhecimento evoluiu muito a partir do curso: recebi informações novas e aprendi a pensar sobre assuntos que não estava acostumado.

Idéia central 4: O curso dá embasamento teórico para compreender a influência dos pais na formação da subjetividade da criança e as diversas modalidades patológicas.

Idéia central 5: O curso permite rever conceitos de Psicanálise, antes interpretados de maneira errônea.

Idéia central 6: A estruturação psíquica do indivíduo ocorre na infância, portanto o tema é fundamental para a abordagem global do pediatra.

\section{IDÉIA CENTRAL 1: Os textos são difíceis, no início, mas necessários para dar sustentação às discussões, que se tornam mais claras com a evolução do curso.}

\section{EXPRESSÕES-CHAVE UTILIZADAS:}

R2 - "No início, foi difícil a leitura dos textos, porém com a evolução dos temas pude me familiarizar melhor com estas leituras e aproveitar melhor as discussões." 
R3 - "No início do curso, especialmente na primeira semana, quando trabalhamos com "O nascimento da Medicina Social", tive bastante dificuldade para ler o texto e, portanto, para me manter concentrada o suficiente para entendê-lo. Percebi isso ainda mais quando a $C$. apresentouo, pois notei que durante sua leitura ela conseguiu retirar muito mais informações e entender melhor o que era dito com estas. No entanto, este tipo de texto era uma total novidade para mim e após a discussão percebi que tinha absorvido bastante informações novas. Com os textos das discussões que se seguiram tive mais facilidade, acho que em parte, porque entrei melhor no esquema da discussão, pois durante a leitura tentava obter minhas próprias opiniões sobre os diferentes tópicos, o que eu não pude fazer no primeiro texto. Gostei bastante do texto "A criança e a contemporaneidade na Psicanálise" e da discussão que tivemos sobre ele, principalmente, pelo retrato histórico da família e pela facilidade de leitura e compreensão."

R4 - "No início do estágio eu achei um pouco difícil acompanhar o raciocínio seguido, principalmente por nunca ter entrado em contato com o assunto. Outro motivo da minha dificuldade inicial é o fato de eu aceitar apenas as informações concretas, quero dizer que é preciso que me prove uma informação para que eu a aceite. Durante o desenrolar do estágio eu fui me adaptando com os tipos de textos e tudo começou a fluir melhor."

R6 - "No início, resistimos, achamos os textos difíceis, mas à medida que o tempo foi passando e as discussões avançando, fomos ficando mais a vontade e com maior intimidade com os assuntos."

R7 - "No início, confesso que houve um certo desconforto de minha parte, principalmente após a leitura dos primeiros textos. Não estava habituada a fazer este tipo de leitura e tive dificuldades para compreender os primeiros textos. Após a discussão, o desconforto melhorou substancialmente, pois novos conceitos foram se estabelecendo ou clareando e as discussões se tornavam ilustrativas e agradáveis. A cada texto a leitura se tornava mais fácil de ser compreendida, embora continuasse uma linguagem difícil, não habitual."

R11 - "Os temas "complicados" abordados pela Psicanálise/Psiquiatria tornaram-se mais claros à medida que as discussões 
foram se desenrolando e deixaram muitas brechas para que mais discussões venham à tona, visto que, de longe, o objetivo do curso era esgotar os temas e sim, introduzir novos pensamentos e informações em nossas reflexões. Os textos abordados foram interessantes e necessários para homogeneizar o conhecimento."

R13 - "Alguns textos foram muito interessante e "gostosos"" de ler, mas outros eu achei muito difícil, pois não estamos acostumados a ler textos aprofundados em Psicanálise."

R16 - "Os textos ajudam a orientar as discussões, embora, às vezes, possuam uma linguagem a que não estamos acostumados, sendo um pouco difíceis de compreender. Acho que mais importante do que os textos são as discussões."

R32 - "A leitura de alguns textos foi difícil, pois não estava habituada a este tipo de linguagem; a maioria do conteúdo teórico que temos contato é tecnicista, com linguagem científica. Em determinados textos, senti que para seu entendimento era necessário o domínio de alguns conceitos que até então, eu não possuía. No entanto, a leitura foi proveitosa, tanto para o exercício de preparação de textos com tal dificuldade, como pelos novos conhecimentos adquiridos."

R36 - "A princípio, os textos foram de difícil compreensão, mas depois que concluíamos as discussões, ao reler, esse se tornava mais simples e compreensível."

R39 - "Confesso que foi muito difícil lidar com textos que traziam questões gerais, porém apresentadas de forma totalmente diferente da que estava acostumada na graduação. Algumas vezes, foi complicado encontrar motivação, pois quando entramos na residência, estamos sedentos por conhecimento técnico, além do mais, estamos totalmente despreparados para este tipo de texto"

R42 - "Achei as discussões muito boas, nas quais pudemos "esmiuçar" os textos e toda a sua subjetividade. Nem todos foram claros para mim e de certa forma foi importante para aprender a treinar minha compreensão sob outras abordagens."

R53 - "Em relação aos textos, de uma forma geral, são bons, alguns tem linguagem difícil para nós, médicos leigos do mundo "psi". Não sei se 
existe disponível textos com linguagem mais coloquial. De qualquer forma, apesar de passar alguns parágrafos sem entender nada, é possível captar a mensagem principal deles."

\section{DSC1}

"No início, a leitura dos textos foi difícil, porém com a evolução dos temas e à medida que as discussões foram avançando pude me familiarizar e ficar mais a vontade, tendo, inclusive, maior intimidade com os assuntos. Não estava habituado a fazer este tipo de leitura e no início do estágio, eu achava um pouco difícil acompanhar o raciocínio seguido, principalmente por nunca ter entrado em contato com o assunto, mas este se tornava mais fácil de ser compreendido a cada texto e tudo começou a fluir melhor. Como o objetivo do curso não era esgotar os temas, mas introduzir novos pensamentos e informações em nossas reflexões, os textos abordados foram necessários para homogeneizar o conhecimento."

\section{IDÉIA CENTRAL 2: Os textos utilizados são pertinentes aos temas e suscitam questionamentos, reflexões e críticas.}

\section{EXPRESSÕES-CHAVE UTILIZADAS:}

R5 - "Os textos parecem ter sido escolhidos de uma forma especial e, em sua grande maioria, tiveram propriedade nos assuntos abordados, nos suscitando questionamentos, reflexões e críticas. Todos eles foram enriquecidos e suas dúvidas elucidadas pelas excelentes discussões em sala."

R30 - "Na minha opinião, os temas abordados no estágio e durante as discussões são bons. O esquema proposto - leitura, apresentação e discussão - é adequado e facilita a compreensão durante as discussões."

R48 - "Achei de extrema importância esta atividade, e apesar de "subjetiva", não se perdeu, por ter sido trabalhada com muita seriedade e 
pela abordagem, sempre embasada em textos, o que sedimentou melhor os assuntos, ao meu ver, durante as discussões."

\section{DSC2}

"Os textos parecem ter sido escolhidos de uma forma especial e, em sua grande maioria, tiveram propriedade nos assuntos abordados, nos suscitando questionamentos, reflexões e críticas. O esquema proposto - leitura, apresentação e discussão - é adequado e as dúvidas são elucidadas pelas excelentes discussões em sala."

\section{IDÉIA CENTRAL 3: Meu conhecimento evoluiu muito a partir do curso: recebi informações novas e aprendi a pensar sobre assuntos que não estava acostumado.}

\section{EXPRESSÕES-CHAVE UTILIZADAS:}

R4 - "Meu conhecimento evoluiu muito, a cada sexta-feira que passava, eu adorava ir ao CS-E para as discussões. Achei muito bom tudo no estágio, "aprendi" a ler textos que não tem aquele formato que estamos acostumados, recebi muitas e muitas informações novas que são muito úteis no dia-a-dia da nossa vida futura (como sobre a formação do sujeito, um tema que após o estágio considero essencial na formação de um pediatra!)."

R21 - "No geral, considero que todos saímos bastante enriquecidos, tanto em nosso conceitos quanto em nossa compreensão dos pacientes e da nossa relação com eles."

R25 - "Acho que as discussões foram super-produtivas, mudaram meu modo de pensar, "abrindo minha cabeça."'"

R32 - "Os temas abordados me levaram a fazer reflexões que nunca havia pensado e a formar algumas opiniões. Acredito que muito do que aprendi me acrescentou primeiro como pessoa do que como médico, mas que inevitavelmente repercutirá no último." 


\section{DSC3}

"Considero que saí bastante enriquecido deste curso, tanto no que diz respeito aos conceitos quanto à compreensão dos pacientes e da minha relação com eles. Meu conhecimento evoluiu muito: "aprendi" a ler textos que não tem aquele formato que estamos acostumados, recebi muitas informações novas que são muito úteis no dia-a-dia (como a formação do sujeito, um tema que após o estágio considero essencial na formação de um pediatra!). As discussões mudaram meu modo de pensar, "abrindo minha cabeça", me levaram a fazer reflexões que nunca havia pensado e a formar algumas opiniões."

\section{IDÉIA CENTRAL 4: O curso dá embasamento teórico para compreender a influência dos pais na formação da subjetividade da criança $e$ as diversas modalidades patológicas.}

\section{EXPRESSÕES-CHAVE UTILIZADAS:}

R9 - "Foi interessante discorrer sobre Édipo e sua influência no crescimento das crianças, da sua importância como modelador de pessoas capazes de tomar decisões, de se desligar da barra da saia da mãe, de encarar o mundo e o cotidiano de um jeito diferente, apreciando as dificuldades como cortes consecutivos do cordão umbilical, ao que fomos expostos inconscientemente em algum momento nas nossas vidas ou pelo menos deveríamos ter sido. É inevitável pensar na influência que nossos pais tem acima de nós, estando presentes ou ausentes, eles marcam nossas vidas, não é à toa que muitas vezes escutamos frases como: "você tem de ser o que eu não consegui ser" ou "não cometas o mesmo erro que eu"; eles vão se entregando para conseguir dar a seus filhos aquilo que eles acham importante, dando ao mesmo tempo exemplos de esforço e dedicação... mas será que o esforço de fazer filhos fortes, preparados para a vida, filhos resilientes, deixa a criança, logo adolescente e depois adulto, preparado para a vida?" 
R10 - "Também foi interessante a abordagem de temas "psi", como o Édipo, a formação do sujeito, a influência materna e a paterna nesse processo, pois embora esses conhecimentos sejam até que populares, espera-se que um pediatra possa oferecer mais do que uma visão leiga do assunto e o curso é bem-sucedido em nos dar embasamento para tal."

R12 - "Foi uma grande oportunidade para refletirmos um pouco sobre as mudanças atuais de comportamento, estrutura familiar e toda a influência dessas mudanças sobre o desenvolvimento infantil, o que não encontramos em livros-textos."

R16 - "O curso teve um conteúdo muito bom e é extremamente importante por trazer para discussão temas como o desenvolvimento na óptica da Psicanálise e da Psicologia. A discussão da importância da relação mãe-filho, estruturação do sujeito e como seus desvios se mostram como sintomas, muitas vezes, referidos nas consultas, foi muito boa."

\section{DSC4}

"Foi uma grande oportunidade para refletirmos um pouco sobre as mudanças atuais de comportamento, estrutura familiar e toda a influência dessas mudanças sobre o desenvolvimento infantil, o que não encontramos em livros-textos. O curso teve um conteúdo muito bom e é extremamente importante por trazer para discussão temas como o desenvolvimento na óptica da Psicanálise e da Psicologia. Foi interessante discorrer sobre Édipo e sua influência no crescimento das crianças, a importância da relação mãe-filho, a estruturação do sujeito e como seus desvios se mostram como sintomas, muitas vezes, referidos nas consultas. Espera-se que um pediatra possa oferecer mais do que uma visão leiga do assunto e o curso é bemsucedido em nos dar embasamento para tal."

\section{IDÉIA CENTRAL 5: 0 curso permite rever conceitos de Psicanálise, antes interpretados de maneira errônea.}


R12 - "Pude esclarecer várias questões, principalmente relacionadas à Psicanálise, as quais antes me pareciam estranhas e até mesmo absurdas. Isso devido à falta de conceitos e definições, que antes acabavam sendo interpretadas de maneira errônea ."

R13 - "Clareou bastante para mim, assuntos da Psicanálise que eu era, muitas vezes, contra. Eu realmente não entendia Freud e agora vejo que há sentido em algumas coisas que ele afirmava."

R25 - "Gostei de aprender um pouco sobre a visão da Psicanálise. Foi um pouco, mas o suficiente para acabarem com alguns dos préconceitos que eu tinha."

\section{DSC5}

"Pude esclarecer várias questões, principalmente relacionadas à Psicanálise, as quais antes me pareciam estranhas e até mesmo absurdas. Isso devido à falta de conceitos e definições, que antes acabavam sendo interpretadas de maneira errônea. Clareou bastante para mim porque realmente eu não entendia Freud e agora vejo que há sentido em algumas coisas que ele afirmava. Foi pouco, mas o suficiente para acabar com alguns dos pré-conceitos que eu tinha."

\section{IDÉIA CENTRAL 6: A estruturação psíquica do indivíduo ocorre na infância, portanto o tema é fundamental para a abordagem global do pediatra.}

\section{EXPRESSÕES-CHAVE UTILIZADAS:}

R31 - "A saúde mental da criança é um segmento que deve ser pensado e estudado por todo pediatra que deseje clinicar, usando uma abordagem global e integral à saúde da criança. Essa importância se torna ímpar quando se leva em consideração que o pediatra tem na Puericultura uma oportunidade de integrar-se ao desenvolvimento e formação do futuro 
adulto. Para que possa fazer Puericultura realmente abordando a saúde da criança, é fundamental que a saúde mental seja levada em consideração. Para isso é importante se conhecer e estudar o psiquismo da criança e daqueles que sobre ela atuam. Mesmo no ambiente da residência, poucos são os lugares e as oportunidades que o residente tem de se aprofundar no mundo que se abre ao iniciarmos o estudo do psiquismo em formação da criança."

R35 - "Acho que o estágio foi muito válido, já que atualmente enfrentamos cada vez mais na prática clínica, problemas da ordem da saúde mental."

R41 - "Principalmente na Pediatria, já que os primeiros anos de vida são básicos para a estruturação psíquica do indivíduo. Assim sendo, as condutas e as orientações que possam assegurar uma correta higiene mental são mais importantes na vida infantil do que na vida adulta."

\section{DSC6}

"A saúde mental da criança é um segmento que deve ser pensado e estudado por todo pediatra que deseje clinicar, usando uma abordagem global e integral à saúde da criança. Para isso é importante se conhecer e estudar o psiquismo da criança e daqueles que sobre ela atuam, já que os primeiros anos de vida são básicos para a estruturação psíquica do indivíduo. As condutas e as orientações que possam assegurar uma correta higiene mental são mais importantes na vida infantil do que na vida adulta, além disso, deve-se considerar que atualmente, enfrentamos cada vez mais na prática clínica, problemas desta ordem."

\section{TEMA 3: AVALIAÇÃO DA DINÂMICA E METODOLOGIAS EMPREGADAS}

Idéia central 1 - A dinâmica do curso permite refletir e compartilhar opiniões, sentimentos e experiências com o grupo. 
Idéia central 2 - As atividades oferecem a possibilidade de conhecer melhor os colegas, enriquecendo os vínculos do grupo.

Idéia central 3 - A metodologia empregada é interessante, pois permite aprofundar os pontos que emergem na leitura dos textos, durante as discussões.

Idéia central 4 - O método de discussão é muito cansativo e pouco produtivo.

\section{IDÉIA CENTRAL 1: A dinâmica do curso permite refletir e compartilhar opiniões, sentimentos e experiências com 0 grupo.}

EXPRESSÕES-CHAVE UTILIZADAS:

R6 - "Foi essencial termos um tempo dedicado a parar, refletir sobre estas questões e poder compartilhar opiniões e experiências com um grupo. "

R18 - "Pode me abranger o ponto de vista, de como entender melhor o outro. É um curso dado de forma muito dinâmica, interagindo todos durante a aula, onde diferentes opiniões podem ser expressas e entendidas."

R23 - "O mais interessante é que o estágio abriu um canal para que pudéssemos expor, além de nossas opiniões, os nossos sentimentos. Fomos tomados, durante as discussões, por momentos de raiva, indignação, conivência, entre outros sentimentos mais difíceis de serem nominados. Foi, sem dúvida, uma experiência interessante. Às vezes, saía da sexta-feira de manhã pensativa... outras, revoltada! Não importa qual o sentimento a vigorar em cada ocasião, uma certeza eu tinha: valeu a pena!"

R26 - "É o único espaço dentro da residência que permite que expressemos nossas angústias em relação às consultas que temos e saber a opinião e os sentimentos de outras pessoas sobre seus pacientes."

R27 - "Gostei também do espaço dado para a discussão das angústias, que nós, residentes, passamos no consultório e na relação com os pacientes." 
R28 - "Pudemos ler e compartilhar opiniões distintas frente a cada assunto e desse modo, enriquecer nossa lógica. Em algumas situações, antes do início das discussões, eu apresentava determinada opinião e, após ouvir o que cada um entendia por determinado tópico, me vi mudando meus conceitos."

R32 - "Discussões: gostei da forma de apresentação dos textos, que por ser informal, dá liberdade para os demais expressarem suas opiniões sobre o conteúdo e trocar idéias."

R34 - "Um ponto positivo é a possibilidade de nós, residentes, também nos expressarmos em relação aos nossos sentimentos para com a etapa da vida em que estamos atravessando. Permite um desabafo e uma orientação do caminho a seguir."

R39 - "Além disso, considero muito importante poder discutir um pouco sobre as dificuldades que estava vivendo nesta experiência de médico-residente, em que tudo era novidade e trazia certos conflitos. Foi reconfortante notar que meus colegas passavam por conflitos parecidos, e que não estava sozinho."

R43 - "A dinâmica através da qual o curso foi exposto também foi muito bom porque lemos sobre um determinado assunto que nos faz pensar sobre o tema e sobre os conceitos e pré-conceitos que temos sobre eles e durante a discussão no grupo reforçamos esses conceitos, excluímos alguns pré-conceitos e aprendemos como a criança pode ser influenciada por ele."

\section{DSC1}

"Foi essencial termos um tempo dedicado para parar, refletir sobre as diversas questões e poder compartilhar opiniões e experiências o grupo. É um curso dado de forma muito dinâmica, em que todos interagem durante a aula, $e$ as diferentes opiniões podem ser expressas e entendidas. Em algumas situações, antes do início das discussões, eu apresentava determinada opinião e, após ouvir o que cada um entendia por determinado tópico, pude mudar meus conceitos. Além de nossas opiniões, pudemos expor também nossos sentimentos. Fomos tomados, durante as discussões, por momentos de raiva, indignação, conivência, entre outros sentimentos mais 
difíceis de serem nominados. Gostei também do espaço dado para a discussão das angústias, que nós, residentes, passamos no consultório e na relação com os pacientes. Foi importante saber a opinião e os sentimentos de outras pessoas sobre seus pacientes. Outro ponto positivo é a possibilidade de nós expressarmos os sentimentos para com a etapa da vida em que estamos atravessando, em que tudo era novidade e trazia certos conflitos. Foi reconfortante notar que meus colegas passavam por conflitos parecidos, e que não estava sozinho. Permitiu um desabafo e uma orientação do caminho a seguir."

\section{IDÉIA CENTRAL 2: As atividades oferecem a possibilidade de conhecer melhor os colegas, enriquecendo os vínculos do grupo.}

EXPRESSÕES-CHAVE UTILIZADAS:

R14 - "Também me trouxe a possibilidade de conhecer melhor meus colegas, possibilitando um melhor vínculo entre nós: um presente de relacionamentos! Uma prática da relação entre as pessoas!!!"

R37 - "Gostei também da primeira discussão, pois apesar de convivermos muitas horas juntos durante o ano, ainda existem coisas que desconhecemos dos colegas e talvez se soubéssemos mais uns sobre os outros poderíamos tornar a residência mais "leve" e mais solidária."

R55 - "No primeiro dia do estágio me foi dada a oportunidade de, pela primeira vez desde o início da residência, parar para ouvir um pouco meus colegas de equipe, saber um pouco mais sobre a vida, a história e as peculiaridades de cada um, o que de imediato, enriqueceu muito o relacionamento entre nós (ganho inestimável, a meu ver)."

\section{DSC2}

"No primeiro dia do estágio me foi dada a oportunidade de, pela primeira vez desde o início da residência, parar para ouvir um pouco 
meus colegas de equipe, saber um pouco mais sobre a vida, a história e as peculiaridades de cada um. Apesar de convivermos muitas horas juntos durante o ano, ainda existem coisas que desconhecemos dos colegas e talvez se soubéssemos mais uns sobre os outros poderíamos tornar a residência mais "leve" e mais solidária, possibilitando um melhor vínculo entre nós. Sem dúvida, foi uma prática de relação entre as pessoas! Um ganho inestimável, a meu ver."

\section{IDÉIA CENTRAL 3: A metodologia empregada é interessante, pois permite aprofundar os pontos que emergem na leitura dos textos, durante as discussões.}

\section{EXPRESSÕES-CHAVE UTILIZADAS:}

R12 - "Acho que a metodologia empregada foi interessante, pois muitas das minhas dúvidas que surgiam durante a leitura, foram esclarecidas no momento da discussão. De modo geral, o aproveitamento foi muito bom (interessante o fato de que acabávamos resgatando várias vezes assuntos discutidos previamente, reforçando o que já havia sido visto)

\section{DSC3}

"Acho que a metodologia empregada foi interessante, pois muitas das minhas dúvidas que surgiam durante a leitura, foram esclarecidas no momento da discussão. Foi possível, também, resgatar os assuntos discutidos anteriormente, reforçando os conceitos."

\section{IDÉIA CENTRAL 4: O método de discussão é muito cansativo e pouco produtivo.}




\section{EXPRESSÕES-CHAVE UTILIZADAS:}

R8 - "Achei o método de discussão muito cansativo. Acho que uma pessoa falando por mais ou menos quatro horas é muito pouco produtivo.. Também acho muito teórico e pouco prático."

\section{DSC4}

"Achei o método de discussão muito cansativo, pois uma pessoa falando por mais ou menos quatro horas torna-se pouco produtivo."

\section{TEMA 4: AVALIAÇÃO DA COORDENAÇÃO}

Idéia central 1 - A coordenadora facilita a compreensão e a reflexão dos temas, conduzindo as discussões com objetividade.

Idéia central 2 - Houve disponibilidade da coordenadora em aceitar sugestões, de acordo com a demanda dos residentes.

\section{IDÉIA CENTRAL 1: - A coordenadora facilita a compreensão e a reflexão dos temas, conduzindo as discussões com objetividade.}

\section{EXPRESSÕES-CHAVE UTILIZADAS:}

R5 - "A facilitadora do curso teve um papel fundamental, ajudandonos a refletir sobre os temas, trazendo exemplos, pensamentos e conclusões de maneira muito inteligente e objetiva."

R24 - "Creio que o curso é conduzido por uma profissional muito bem capacitada, não-autoritária e interessada a respeito de qualquer assunto trazido às discussões."

R42 - "Raquel teve abordagem fácil de ser compreendida e apesar de toda a subjetividade dos temas, tudo fica de certa forma, muito claro." 
R56 - "O sucesso desta atividade está vinculado a uma estruturação bem estabelecida, há um plano pensado e estruturado para esta atividade, além do fato dessa atividade ser comandada por uma profissional muito competente em sua área e que consegue expor com clareza suas idéias e de maneira interessante."

\section{DSC1}

"Creio que o curso é conduzido por uma profissional muito bem capacitada, não-autoritária e interessada a respeito de qualquer assunto trazido às discussões. A coordenadora teve um papel fundamental, ajudando-nos a refletir sobre os temas, trazendo exemplos, pensamentos e conclusões de maneira muito inteligente e objetiva. Além do mais, ela consegue expor com clareza suas idéias e de maneira interessante."

\section{IDÉIA CENTRAL 2: Houve disponibilidade da coordenadora em aceitar sugestões, de acordo com a demanda dos residentes.}

\section{EXPRESSÕES-CHAVE UTILIZADAS:}

R32 - "Considerei importante a sua disponibilidade em aceitar sugestões, conforme a demanda dos residentes, como foi o caso do tema "adoção"."

\section{DSC2}

"Considerei importante a disponibilidade da coordenadora em aceitar sugestões, conforme a demanda dos residentes, como foi o caso do tema "adoção"."

\section{TEMA 5: SUGESTÕES}


Idéia central 1 - A apresentação dos temas deveria ficar sob responsabilidade de duas pessoas.

Idéia central 2 - Poderia se introduzir outras dinâmicas, para tornar as discussões mais interessantes.

Idéia central 3 - Seria interessante discutir mais casos de crianças com distúrbios de comportamento, pois não sabemos como abordar.

Idéia central 4 - Sugiro acrescentar outros temas.

Idéia central 5 - Gostaria que houvesse discussões periódicas, pois tenho interesse em estudar mais autores e temas.

Idéia central 6 - As discussões deveriam se estender por todo o programa de residência para dar suporte psicológico aos residentes.

\section{IDÉIA CENTRAL 1: A apresentação dos temas deveria ficar sob responsabilidade de duas pessoas. \\ EXPRESSÕES-CHAVE UTILIZADAS:}

R1: "Gostaria de fazer uma sugestão: ao invés de uma pessoa ficar responsável por um tema, acredito que duas pessoas poderiam ser incumbidas. Ás vezes, tinha a impressão de que, durante a apresentação do tema, as pessoas ficavam meio perdidas, meio aéreas (quando os textos eram longos ou mais complexos). Talvez deixando dois responsáveis, a apresentação flua melhor."

\section{DSC1}

"Gostaria de fazer uma sugestão: ao invés de uma pessoa ficar responsável por um tema, duas pessoas poderiam ser incumbidas, talvez a apresentação flua melhor."

\section{IDÉIA CENTRAL 2: Poderia se introduzir outras dinâmicas, para tornar as discussões mais interessantes.}




\section{EXPRESSÕES-CHAVE UTILIZADAS:}

R11 - "No entanto, eu acredito que a apresentação destes pelos residentes na seqüência de anotações do texto pode tornar a abordagem menos interessante e mais dispersiva do conteúdo. Talvez o uso de dinâmicas, vídeos e discussões ao redor de questões que abordem os pontos mais importantes dos textos possam tornar os temas enfocados mais interessantes."

R13 - "Mas a pessoa que apresenta praticamente lê o texto. Talvez se tivesse questões orientadoras ou tópicos para maior reflexão e opinião do grupo, seria mais interessante."

R34 - "Outras atividades como simulações e questionários sobre o tema também aprimorariam os debates."

R56 - "Sugiro que, talvez, possa ser inserido como base para discussão além dos textos, um roteiro de perguntas que enfoque pontos mais fundamentais sobre o tema abordado."

R58 - "A idéia de lermos textos para nos embasar para as discussões é muito boa, porém, às vezes, ficamos muito presos ao seu seguimento e perdemos a possibilidade ou espaço para relatarmos acontecimentos pessoais. Sugiro que pudéssemos ler não só textos científicos, como também reportagens ou quaisquer outros documentos."

\section{DSC2}

"Sugiro inserir como base para discussão, além dos textos, um roteiro de perguntas que enfoque pontos mais fundamentais sobre $o$ tema abordado. Outras atividades como simulações, vídeos, reportagens e questionários sobre o tema também aprimorariam os debates." 


\section{IDÉIA CENTRAL 3: Seria interessante discutir mais casos de crianças com distúrbios de comportamento, pois não sabemos como abordar.}

\section{EXPRESSÕES-CHAVE UTILIZADAS:}

R7 - "Não sei como isso seria possível, mas acho que seria interessante também um espaço para discussão sobre a criança e a mídia, que não foi realizada em função do tempo e sobre distúrbios de comportamento em crianças, que muitas vezes entramos em contato e não sabemos como abordar."

R8 - "Sugiro que os textos sejam dados para serem lidos e discutidos, porém acho que também podem ser discutidos métodos práticos de consulta com crianças, casos clínicos de crianças com problemas psicológicos (por exemplo, depressão, fracasso escolar, dificuldade de alimentação)."

R19 - "Foi bem proveitoso, mas sugiro, se possível, maior discussão de casos clínicos relacionados a alguns tópicos, para sedimentar ainda mais o rico conteúdo das discussões. Sugiro que fracasso escolar, depressão e psicoses na infância, por exemplo, sejam ilustrados com discussão de caso."

R24 - "Os temas escolhidos nos fazem pensar, trazem novos elementos às nossas vidas, ou seja têm seus objetivos e seus pontos positivos. Porém, não ajudam, de forma prática, a identificar psicopatologias pediátricas ou como lidar na suspeita das mesmas."

R27 - "Uma sugestão seria reservar um tempo para a discussão de alguns temas específicos de psicopatologias pediátricas."

R30 - "Críticas: Acho que alguns dos temas e algumas discussões não tocam o nosso dia-a-dia. Falta um pouco de praticidade, ou seja, as discussões deveriam poder ser utilizadas para a prática. Em alguns caso, por exemplo, no seminário sobre família e depressão, falou-se de Édipo, que a criança é um livro aberto a novas experiências... afinal, como eu reconheço depressão em uma criança? O que eu devo fazer? Encaminhar? Para quem? É válido nós termos noção das teorias psicanalíticas e de seus fundamentos, desde que possa ser aplicado à prática, como eu já havia 
falado no início do estágio, eu esperava que não fossem só teorias e pensamentos, e sim uma visão prática, de como atuar nessas situações (o que eu, particularmente, acho muito difícil!)."

R32 - "No entanto, nesta fase de nossa formação o nosso maior anseio é a aplicabilidade clínica do que aprendemos e necessitamos que esta aplicação seja concreta, vivenciada. Tenho muita dificuldade em abordar determinados aspectos da saúde mental da criança e como conduzi-los. Foi muito interessante quando discutimos um caso clínico (do paciente de um residente), mas nem sempre temos esta demanda. Gostaria de deixar como sugestão que você trouxesse para a discussão alguns casos que considerasse ilustrativos e assim termos mais discussão clínica."

R34 - "Creio, que apesar de muito bem conduzidas, as discussões poderiam ser mais bem aproveitadas com a utilização de recursos mais práticos, como vídeos e relatos de caso trazidos à aula. Às vezes, fica difícil trazer casos dos residentes que sejam compatíveis com o que está sendo abordado."

R35 - "Acho que poderiam ser discutidos mais casos clínicos para ilustrar, na prática, os temas discutidos."

R36 - "A sugestão que faço seria estabelecer um horário para toda aula discutirmos um caso. Se, por ventura, não for trazido pelos residentes, poderia ser do I.Cr., visto que no nosso estágio foram insuficientes, por falta de assunto. Tivemos poucas discussões, mas que foram suficientes para mostrar sua efetividade na prática médica."

R37 - "A proposta da divisão do tempo também é válida e acho que se possivel, deve ser mantida a discussão de pelo menos um caso/manhã, pois com exemplos, a aplicação prática se torna mais "palpável" para nós."

\section{DSC3}

"Acho que também podem ser discutidos métodos práticos de consulta de crianças com problemas psicológicos. Por exemplo, depressão, fracasso escolar, psicoses, dificuldade de alimentação poderiam ser ilustrados com discussão de casos clínicos. Isto nos ajudaria a identificar psicopatologias pediátricas ou como lidar na suspeita das mesmas. O que eu devo fazer? Encaminhar? Para quem? 
Às vezes, fica difícil trazer casos que sejam compatíveis com o que está sendo abordado. Gostaria de deixar como sugestão que você trouxesse para a discussão alguns casos que considerasse ilustrativos e assim suprir o nosso maior anseio que é a aplicabilidade clínica do que aprendemos."

\section{IDÉIA CENTRAL 4: Sugiro acrescentar outros temas.}

EXPRESSÕES-CHAVE UTILIZADAS:

R37 - "Senti falta de temas contemplando o desenvolvimento psicossocial da criança para que possamos avaliá-la melhor e identificar precocemente os casos necessários."

R56 - "Também sugiro como outro tema a ser abordado as doenças ou manifestações psicossomáticas, pois este é bastante prevalente na prática pediátrica e há dificuldade por parte dos pediatras para lidar com estas manifestações."

\section{DSC4}

"Senti falta de temas como o desenvolvimento psicossocial da criança, que é importante para avaliar e identificar precocemente os casos que necessitam de trabalho específico, bem como as doenças ou manifestações psicossomáticas, bastante prevalentes na prática pediátrica e onde existe dificuldades quanto à abordagem."

\section{IDÉIA CENTRAL 5: Gostaria que houvesse discussões periódicas, pois tenho interesse em estudar mais autores e temas.}

EXPRESSÕES-CHAVE UTILIZADAS: 
R2 - "Eu, particularmente, tenho interesse em estudar mais sobre Freud, Piaget ... Pessoalmente, foi muito bom este contato com a Psicologia/Psicanálise, e gostaria de participar periodicamente em tais tipos de discussões."

R16 - "É pena que o curso seja tão curto, restrito apenas ao estágio de Pediatria Comunitária, já que o tema é muito amplo e merecia ser extrapolado para os outros estágios, pois acho fundamental a discussão da esfera psíquica do desenvolvimento da criança, bem como das relações familiares e da criança com o meio."

R31 - "Realmente, gostei muito do curso e me arrisco a dizer que, tendo em vista a riqueza de influências a que a criança está sujeita, este curso poderia ser estendido, sem o risco de se tornar repetitivo ou vazio."

R40 - "Tive uma visão muito positiva do curso e acho que as discussões deveriam se estender por todo ano e se possível, como todos os residentes juntos, poderia ser feito uma vez por mês no mesmo horário das aulas de Ped. Comunitária."

R44 - "De qualquer forma, achei muito importante para minha formação como pediatra (e para o meu crescimento como ser humano) e acho que seria muito importante a continuação desse trabalho, afinal 10 semanas é muito pouco tempo..."

R51 - "Os temas discutidos foram extremamente interessantes e com certeza, haveriam muitos outros a serem discutidos, caso o tempo disponível fosse maior. Seria, então, muito interessante ter outras oportunidades durante a residência para dar continuidade a este trabalho."

R56 - "Outra sugestão é de que esta atividade seja estendida para todo o ano, já que ela não é específica da Pediatria Comunitária e pode ser adequada e bem aproveitada em toda a residência médica, contribuindo para discussão de dúvidas que surgem no decorrer do ano, com a relação médico-paciente e suas nuances que estão sempre em processo de aprendizagem."

\section{DSC5}

"É pena que o curso seja tão curto, restrito apenas ao estágio de Pediatria Comunitária, já que o tema é muito amplo e mereceria ser 
estendido por toda a residência. Tenho interesse, inclusive, em estudar mais sobre Freud, Piaget etc. $O$ contato com a Psicologia/Psicanálise foi muito bom, e gostaria de participar periodicamente desse tipo de discussão."

\section{IDÉIA CENTRAL 6: As discussões deveriam se estender por todo o programa de residência para dar suporte psicológico aos residentes.}

\section{EXPRESSÕES-CHAVE UTILIZADAS:}

R52 - "Acho esta atividade extremamente necessária, e senti que deveria se estender durante o ano todo - com objetivo não apenas de abordar os aspectos psíquicos das crianças, mas também dos residentes. Nós passamos por muitas situações e não encontramos espaço para discutilas. Apesar da existência do GRAPAC, o que sugiro é uma discussão com o grupo - dividir as angústias e dúvidas, afinal estamos todos no mesmo barco, e pior, sem qualquer suporte psi."

R53 - "Acho, ainda, que este curso teve uma outra função extraprogramação que foi a de amparar os residentes, ouvindo e discutindo sobre os assuntos que os afligem. É uma pena que dure apenas dois meses, vamos sentir muita falta deste local para "desabafo" durante o resto do ano. Se pudesse dar uma sugestão seria de que estas reuniões perdurassem por todo ao ano. Afinal é importante cuidarmos da nossa saúde mental, certo?"

\section{DSC6}

"Acho que este curso teve uma função extra-programação que foi a de amparar os residentes, ouvindo e discutindo sobre os assuntos que nos afligem. Isto deveria se estender ao longo de todo ano - com objetivo não apenas de abordar os aspectos psíquicos das crianças, mas também dos residentes. Nós passamos por muitas situações e não encontramos espaço para discuti-las. Sugiro que isto seja feito 
em grupo - dividir as angústias e dúvidas - afinal, é importante cuidarmos da nossa saúde mental, certo?"

\subsection{Sobre os significados e análise dos discursos-síntese}

Uma vez caracterizados os discursos dos sujeitos coletivos, referenciados a partir dos temas que elencamos como os mais importantes no tratamento dos dados, passaremos ao trabalho de análise e discussão, resgatando esses discursos um a um.

\section{Avaliação geral}

Cabe assinalar que uma grande parte dos residentes teceu várias considerações gerais sobre o curso, tal como foi solicitado e pareceu-nos importante destacar justamente esses comentários de caráter mais genérico, que nos pareceu bastante reveladores.

\subsection{DSC1}

"Tinha uma idéia diferente do curso, antes do seu início. Acreditava que a abordagem dos temas seria pautada pelos casos recebidos no CS-E, ou talvez, de um curso teórico, onde aprenderíamos técnicas "psi" para lidar com diversos assuntos (violência, adoção, papéis materno e paterno...) muito comuns na prática pediátrica. Percebi, no entanto, que se tratava de coisa muito diferente de um "manual" de assuntos psicológicos/psiquiátricos. Surgia a oportunidade de ler textos, algumas vezes controversos, muitas vezes também extremamente subjetivos, mas que colocavam devidamente os assuntos em pauta. Eles me ajudaram a enxergar a Pediatria sob um prisma diferente, trabalhando questões "novas" e de uma forma nãohabitual. E as mais variadas opiniões e observações sobre os temas 
em questão apareciam. Confesso que tive uma surpresa bastante agradável com a proposta apresentada. Considero este curso algo peculiar, numa formação tão tecnicista e impessoal."

Notamos neste fragmento a importante reversão quanto às expectativas do curso de saúde mental, inicialmente imaginado como um curso teórico ou prático pautado no uso de técnicas. É referida também a idéia da utilização de um manual, provavelmente seguindo o estilo consagrado através dos "Guide lines", ou manual de bolso que "contemple desde o atendimento primário até 0 terciário, abrangendo os vários sistemas orgânicos, do recém-nascido ao adolescente (...), um guia compacto e claro". Esta modalidade de transmissão de conhecimento elenca todos os assuntos importantes relacionados a cada especialidade, vale lembrar, "com o objetivo de se constituir em guia de acesso fácil para o diagnóstico e conduta médica, a fim de ser usado no dia-a-dia do médico-residente" (DINIZ e col, 2004).

Ao considerarmos a prática médica e suas inflexões, de acordo com QUEIROZ (1986), pode-se afirmar que até o século XVIII, o paciente situava-se no centro do processo de tratamento e cura, compreendido em sua totalidade. Esta prática realizada "no leito" fundamentou todo o sentido da clínica, cuja premissa sustentava a idéia da doença como resultado do relacionamento do sujeito com seu meio. A partir da revolução industrial e da crescente urbanização, a Medicina passa a incorporar pretensões objetivantes traduzidas na busca dos processos patológicos, correlacionados aos sintomas e sinais. Neste momento, os personagens principais passam a ser os médicos e as doenças (isoladas dos doentes). Por último, graças aos progressos técnico-científicos, promovidos pelo método experimental, a Medicina passa a ser entendida como uma ciência natural e o doente ganha o estatuto de caso clínico, cujo organismo é o suporte privilegiado de intervenção. 
Esta síntese que organiza em grandes períodos a evolução científica do campo biomédico pareceu-nos útil para compreendermos as mudanças ocorridas e sua articulação no processo de formação médica. Se a prática médica desenvolveu-se graças a transformação de uma cosmologia voltada para o sujeito humano para uma cosmologia voltada para o objeto, é possível afirmar que a despeito dos enormes avanços no conhecimento, perdeu-se uma visão unificada do doente e das constantes interações deste com o seu mundo .

Observamos, neste fragmento, o destaque dado à oportunidade de refletir sobre uma visão consolidada da Pediatria, qual seja, a necessidade de se "localizar" a doença no organismo e lançar mão de todos os recursos disponíveis para tratá-la e eventualmente curá-la. Os assuntos apresentados em nossa proposta refere-se a uma realidade muito mais ampla e complexa que demanda um tipo de abordagem por parte do médico que não se encontra nos manuais e que exige um outro tipo de posicionamento.

\subsection{DSC2}

"Em minha opinião, o curso de Saúde Mental, como parte do estágio em Pediatria Comunitária, foi excelente. Gostei muito dos textos propostos, mas principalmente das discussões, que nos permitiu aprender mais sobre temas comumente enfrentados em nosso ambulatório didático e com um enfoque distinto da Psiquiatria. Acho que aproveitei o que podia e gostaria de tê-lo realizado no início do ano."

É possível entrever, pela expressiva manifestação nas avaliações do quanto o curso não apenas agradou e interessou aos residentes, mas da sua articulação com a vivência clínica que foi complementada através das discussões realizadas. Ressalta-se, 
novamente, que os limites do campo deste trabalho extrapolam as já conhecidas, como foi notado pela diferença com a Psiquiatria. Outro aspecto, parece-nos ser a da possível aplicação e a utilidade do que foi abordado no curso em outras experiências do Programa de Residência.

\subsection{DSC3}

"As discussões das sextas-feiras foram muito interessantes, já que pudemos refletir sobre assuntos relevantes e que foram pouco abordados na graduação e na residência médica. Foi muito interessante entrar em contato com outro profissional da saúde da criança que tivesse uma formação não-médica. Deste contato, pudemos conhecer outros modos de interpretação dos problemas comuns que encontramos na clínica pediátrica e que, infelizmente, não são muito valorizados na nossa formação acadêmica, que acaba sendo muito técnica e, paradoxalmente, pouco humanizada. A abordagem de temas relacionados ao psiquismo da criança e de como lidar com os aspectos da subjetividade da criança são de grande valia para nós, residentes, já que não temos tal abordagem em nenhum outro segmento da nossa formação e sabe-se que o desenvolvimento da criança está intimamente relacionado com a preservação de seu psico-emocional em condições adequadas. Muitos dos temas, pelo menos para mim, nunca haviam sido abordados durante a graduação, tivemos a oportunidade para entender e discutir sobre questões que como pediatra não temos acesso e nem base para enfrentar, como situações novas de família: pais homossexuais, pais sozinhos que cuidam dos filhos, pai que faz papel de mãe e vice-versa, criança e mídia, adoção, violência, depressão, relação médico-paciente, o suicídio na infância e adolescência (fato que me chocou de certa forma). Estas discussões contribuíram para aumentar a minha visão do ser biopsicossocial (esse sim, tão falado na faculdade, mas tão pouco abordado, de fato) e a oportunidade de debate no curso de residência foi uma surpresa, já que nossa formação está mais 
direcionada para as patologias puramente "orgânicas". Como pude concluir no decorrer do curso, esses temas são importantíssimos, pois a consulta pediátrica envolve muito a parte psicossocial da criança. Acho que estes temas, importantes e presentes nas nossas atividades práticas ambulatoriais, muitas vezes não são abordados por serem difíceis, por falta de conhecimento sobre o assunto, pela sensação de não-resolutividade - porém, na verdade, nosso papel muitas vezes será apenas de esclarecer e orientar, muita pretensão querer resolver o problema de todos."

Encontramos vários aspectos que podem ser analisados e discutidos a partir deste recorte. Primeiramente, a constatação de que os assuntos tratados, embora sejam considerados problemas comuns na prática cotidiana não foram aprofundados tanto na graduação como na residência. Abre-se, a partir do contato com o profissional de outra área a percepção da importância da subjetividade da criança e da família como um elemento-chave para a abordagem do pediatra. Note-se que este constitui nosso principal interesse, conforme já destacado na apresentação da nossa proposta de ensino, qual seja, "a construção de uma prática pediátrica que contemple a singularidade do indivíduo e a possibilidade de se construir uma prática médica que articule as questões subjetivas da criança e da família aos problemas que são dirigidos ao pediatra, passou a traduzir o enorme desafio que sustenta nossa tarefa de ensino".

Entretanto, surge a questão: por que temas comuns e pertinentes à prática não são abordados durante a formação? Podemos levantar como hipótese explicativa o predomínio de uma visão, denominada comumente como organicista, que pode ser traduzida como hegemônica e tradicional nas escolas médicas, de acordo com os depoimentos dos residentes. Disciplinas como Psicologia Médica, por exemplo, propõem um contato com as teorias em Psicologia, restringindo à explanação das mais diversas correntes 
ou escolas, mas não ocorre articulação com as vivências enfrentadas pelo médico. Nesse sentido, o curso visa uma mudança do entendimento da própria formação e propõe a construção de um trabalho no grupo, a partir das discussões, de uma compreensão mais abrangente daquilo que é vivido, conforme foi citado: "situações novas de família, violência, relação médicopaciente" e assim por diante.

Nossa proposta, parece, portanto coincidir com a necessidade detectada sobre o ensino de Pediatria nas escolas médicas, de acordo com PUGA e col (2000), quando afirma que urge "a necessidade de se rever os conteúdos a serem ministrados e as habilidades a serem adquiridas de modo a fazer com que o futuro médico se forme com uma nova filosofia de atenção à saúde" ( $p$. 304), ao tratar da definição dos parâmetros básicos do ensino médico. Assinala-se que estes podem ser resumidos ao desenvolvimento da capacidade do profissional voltada para "a assistência aos problemas familiares numa sociedade em fase de mudança". Ou melhor: "a ênfase é colocada no conhecimento dos mecanismos que levam à enfermidade, integrando as ciências básicas com a prática clínica, o conhecimento do ambiente e os condicionantes sociais, a concepção holística do indivíduo, abarcando os cuidados de saúde numa perspectiva mais ampla, indo desde a sua prática até os hábitos de vida" (PUGA e col., p. 304).

Conforme apontamos no capítulo dedicado à Educação Médica, vale ressaltar que a partir do Relatório Flexner, ocorreu uma importante reorientação no processo de formação médica assentado em bases científicas. Isto implicou na construção de um campo de conhecimento e de prática fortemente comprometido com recursos tecnológicos, impulsionando não apenas um grande avanço das 
especialidades médicas, como também para o processo de fragmentação na abordagem do indivíduo.

Retomando as contribuições fornecidas por DONNANGELO (1976), ao analisar os movimentos da Medicina Integral e Preventiva, a partir do século $X X$, observamos uma crítica importante a um tipo de prática contrária a uma concepção globalizadora do indivíduo. A consolidação destes movimentos foram importantes historicamente ao levantarem a necessidade da inclusão do paciente em um campo de relação, onde a família adquire especial destaque e aponta para o conceito da prática médica como uma prática social e não simplesmente técnica, necessitando, portanto de outros instrumentos para a abordagem do paciente. Observa-se, entretanto, que embora problematizadores deste tipo de prática, estes movimentos sustentam-se como campo próprio, não exercendo uma influência tão expressiva para uma transformação realmente efetiva desta prática.

Pode-se observar, portanto, uma "perda" importante no que diz respeito ao aprendizado do entendimento de aspectos da vida do paciente, que são reconhecidos nesta narrativa como a "parte psicossocial", que são referidas como pouco valorizados durante a formação.

Em relação à Pediatria, isto fica mais evidente, na medida em que a criança está sempre articulada e submetida a seus cuidadores, que de certa forma, funcionam como intermediários na relação com o médico. Torna-se necessário, portanto, o domínio de outros conteúdos oriundos da Ciências Humanas, entre os quais a Psicanálise se coloca, para o processo de formação do médico não somente na residência, como também na graduação que forneçam elementos para um outro tipo de abordagem. 


\subsection{DSC4}

"Acredito que na primeira sexta-feira do estágio se iniciou um processo que não cessará com o final do estágio, afinal muitas questões foram despertadas, pontos de vista foram mudados, os temas selecionados foram muito bons pois nos abriram campo para discussões bastante interessantes. Um outro aspecto foi entrar em contato com textos de outras áreas como Psicologia/Psicanálise, muitas vezes textos difíceis de serem lidos. Porém, acho interessante poder entrar em contato com esses textos que nos "abrem horizontes", pois não o faria espontaneamente. As discussões foram enriquecedoras, passamos a enxergar, por exemplo, que junto com um bebê que cresce, se desenvolve também um sujeito. O curso de saúde mental foi muito proveitoso, pois fez a gente realmente pensar (o que falta um pouco nos outros estágios da residência). Certamente, não termino o curso dominando nenhum dos assuntos, mas saio com interesse em estudar sobre todos eles. Saiba que despertar meu interesse sobre assuntos "psi" foi um feito inédito."

Com efeito, podemos notar uma certa resistência em entrar em contato com a área de Psicologia/Psicanálise tanto quando a dificuldade de leitura é referida como no aspecto ressaltado de que este contato não seria feito espontaneamente. Entretanto, estas impressões são rapidamente diluídas, na medida em que se percebe a importância e pertinência dos assuntos tratados. $O$ potencial transformador apontado sugere uma característica importante da função desta atividade. 
Cabe destacar, neste momento, a possibilidade da proposta levantar a discussão do entendimento da Medicina como um campo de prática e de conhecimento que não pode ser reduzido a uma única disciplina. Ocorre a necessidade de um enfrentamento quanto ao seu objeto de natureza biológica, social e psicológica, que "em função de sua diversidade, abre amplas perspectivas para a presença de várias disciplinas e tendências na análise dos problemas que apresenta" (ALVARENGA, 1994, p. 33), demandando portanto a construção de um campo multi e interdisciplinar.

Outro ponto importante que se depreende deste relato referese à sensibilização do residente para a relação médico-paciente, na medida em que este passa a reconhecer a criança como sujeito. Este aspecto abre uma dimensão pouco trabalhada e elaborada no processo de formação médica, conforme já discorremos anteriormente e que merece destaque, que é o da dimensão propriamente humana presente nesta relação. Isto nos remete à discussão atual no contexto das práticas de saúde sobre a necessidade de se incorporar as noções de humanização e cuidado como referências efetivamente transformadoras, ao resgatarem não somente a subjetividade do paciente, como também a do profissional (AYRES, 2004; REIS e COLS., 2004).

\subsection{DSC5}

"Aprendi muito, certamente este foi um momento bastante marcante de minha formação e continuarei colhendo os frutos, ao longo de minha vida profissional e pessoal. Creio estar agora com olhos e ouvidos mais atentos para os aspectos da relação mãe-filho e do desenvolvimento emocional da criança. Foi possível, também, entender melhor meus sentimentos em relação ao paciente e como posso tentar melhorar o vínculo com alguns deles. Além disso, me fez 
entender porque alguns pacientes e suas família têm determinados comportamentos. Interessante notar que foi o único espaço da residência reservado para discussões de questões éticas e psicossociais da criança. A criança é um ser em desenvolvimento físico, mental, emocional, social etc e está sujeito a influências do meio. Por isso, é necessário conhecer e avaliar tudo o que envolve a vida da criança, o contexto familiar no qual essa criança está inserida, sua vida social, seus contatos, suas atividades diárias e como ela é capaz de lidar com situações novas e, às vezes, hostis. A criança é um indivíduo que está formando sua personalidade e tudo o que acontecer em sua vida ou ao seu redor neste período, ajudará consciente ou inconscientemente, positiva ou negativamente, na formação de sua personalidade. Desta forma, acredito que este curso me ajudou a entender um pouco do que influencia a vida da criança e de como a criança pode expressar essas influências."

A atividade indica uma avaliação positiva sobre o aprendizado, no sentido dos conteúdos que foram adquiridos. No plano cognitivo, destaca-se a importância do vínculo mãe-filho para a compreensão do desenvolvimento emocional da criança.

A percepção dos aspectos envolvidos na relação médico-paciente é mencionado como fundamental para compreender a questão do vínculo como um elemento operacional para o trabalho do médico. Este nível se articula a um plano afetivo do próprio residente, que pode então concluir "porque alguns pacientes e suas famílias têm determinados comportamentos", demonstrando que existe possibilidades de intervenção quando assinala "posso tentar melhorar o vínculo com alguns deles".

Conforme consideramos anteriormente, ao descrevermos os objetivos desta atividade, notamos que foi possível alcançar aquele que se refere a "propiciar ao residente o desenvolvimento da sua capacidade de reflexão e de senso crítico sobre sua ação, sua 
postura ética e seu papel social, utilizando como eixo para a análise a relação médico-paciente".

Este recorte sugere que o espaço oferecido para as discussões promoveu tal intenção. Vale notar que este espaço foi nomeado como sendo o "único reservado para discussões éticas e psicossociais da criança". No decorrer do Programa de Residência, outros profissionais, inclusive da equipe do Serviço de Psiquiatria e Psicologia, se ocupam deste tipo de discussão, em outros estágios, no entanto, a sensibilização para a importância do tema parece já ter sido contemplada.

Finalmente, ao ser levantado a relevância do pensar sobre as influências que a criança sofre e como esta pode expressá-la, nos conduz ao nosso outro objetivo proposto que seria o de "capacitar o residente a articular as questões subjetivas da criança e da família aos sintomas que são trazidos e problematizar essas demandas de intervenção e de resolução de problemas". Parecenos constituir-se uma evidência empírica que a percepção mais ampliada do que foi reconhecido como "influências sobre a criança" colabore para uma prática que aprofunde mais sua investigação e não se ocupe tão somente com as condutas que devem ser tomadas.

\subsection{DSC6}

"O curso contribuiu muito para ampliar a visão da Pediatria geral, abrir oportunidades de avaliar tópicos que estão presentes na sociedade contemporânea, que não são abordados em um anamnese e, portanto, ir além do "peso-altura-mamadeira-cocô-queixas orgânicas". Como, por exemplo, a relação entre os pais e destes com seus filhos, os papéis desempenhados em casa, a abordagem da violência doméstica. Na minha opinião, a consulta não pode e não deve se restringir somente à queixa orgânica, por vários motivos. 
Primeiro, porque essa queixa, conscientemente ou não, leva a uma angústia/dúvida/medo, tanto para a família, como às vezes, para a própria criança. Segundo, porque pode haver relação de causa e efeito entre a queixa e o aspecto psicológico. Por isso, ter a oportunidade de discutir sobre o assunto é de extrema importância para a formação de um profissional completo. Além de nos ampliar a visão em relação ao paciente, os temas abordados, nos permitiram avaliar um pouco as possíveis interações da criança com o meio, em diversos sentidos. Como a criança é vista atualmente pela sociedade? Que papel ela exerce? A que distúrbios psicológicos ela está submetida? Quais são as aspirações da juventude de hoje? A união da Pediatria à Psicologia é perfeita pela necessidade de se ter uma visão holística do ser humano. Por mais que as especialidades da Medicina sejam relevantes, os especialistas atuais não devem se afastar da situação global do indivíduo. Perceber o paciente em toda a sua dimensão é o que existe de mais moderno, sensato e humano nos dias de hoje."

É importante sublinhar a constatação que este fragmento aponta que é de uma relação inequívoca entre os assuntos que devem ser tratados numa consulta pediátrica ("peso-alturamamadeira-cocô-queixas orgânicas") e o mundo de relações da criança. Nos diferentes relatos é referida a oposição psíquico/orgânico como algo extremamente indesejável, já que estes não devem ser pensados como antagônicos ou excludentes, mas como complementares.

Pareceu-nos bastante incorporado pelo residente a concepção de que compreender o universo que cerca a criança, sobretudo o modo de relação que estabelece com os que a rodeiam, está intimamente ligado à produção de queixas e sintomas que são endereçadas ao médico. Conforme o discurso de "pode haver relação de causa e efeito entre a queixa e aspecto psicológico". 
Outro ponto mencionado, digno de comentário, relaciona-se à idealização de uma visão holística ou global, como um desejo que se reitera na prática, a despeito de uma formação dirigida para os aspectos orgânicos do ser humano.

\subsection{DSC7}

"O curso se destaca por tentar mostrar a realidade em que estão inseridas as crianças, sua família, o conceito e a formação histórica do núcleo familiar. Tudo isso mostra um detalhamento e uma riqueza que, se bem explorado na prática clínica, pode dar pistas importantes para o melhor acompanhamento do paciente. Em certos casos que vejo no ambulatório, deu para entender melhor a dinâmica familiar e até conhecer melhor o "sujeito". Nossas discussões ampliaram a visão dos fatores que estão envolvidos nas queixas trazidas, de maneira um pouco mais profunda, menos imediatista e menos "causa-efeito". Elas também deram suporte para buscarmos respostas e compreensão das dificuldades que envolvem a relação entre pais e filhos e até mesmo para nos prepararmos como futuros pais e mães. Foi possível aproveitar os temas em outros momentos, como por exemplo, em algumas aulas do Ambulatório do HU e mesmo no Posto de Saúde, durante as discussões sobre desenvolvimento, nos estágios da creche e nas discussões realizadas às quintas-feiras. Mas meu maior ganho mesmo foi perceber que cada vez mais a Medicina tem trazido para si a valorização do paciente como um ser único, como um indivíduo completo e que criar vínculos verdadeiros, preocupar-se, solidarizar-se, alegrar-se e até sofrer com e pelo paciente significa exercer uma Medicina com muito mais sentido. Enfim, trouxe-me elementos úteis para minha prática médica e para a vida!"

Notamos o caráter prático que tal atividade enseja, uma vez que foi reconhecida a possibilidade de aplicar os conhecimentos em outras esferas (nas consultas, em discussões, experiências pessoais), 
com importante benefício. Novamente aparece o entendimento da prática médica marcada pela "valorização do paciente como um ser único", portanto, que resiste à generalização e à homogeinização, assim como à fragmentação ou redução.

\subsection{DSC8}

"O curso está bem colocado no primeiro ano da residência, época em que estamos compreendendo a criança de forma mais generalista, e foi bem inserido durante o módulo de Pediatria Comunitária, onde a clientela atendida (na maioria, moradores da favela próxima) nos ilustrava as várias questões abordadas. Este curso é extremamente necessário em nosso programa de residência, pois esta é vivida em um ambiente estressante, em que somos considerados uma mão-de-obra para "tocar o serviço" onde se desenvolve muito a ciência e se esquece um pouco o lado humano. É importante lembrar, também, que por trás do residente existe um ser humano, como qualquer outro, com medos e angústias e que está disposto a resolver o problema de seu paciente e este, por sua vez, ao procurar o médico, na maioria das vezes, vem fragilizado, inseguro e temendo sobre alguma desarmonia biopsicossocial."

Observa-se a adequação do curso ao Programa de Residência e sua localização no estágio de Pediatria Comunitária como pertinente e necessário.

Importante notar a associação entre o espaço aberto pelas discussões à percepção do residente como um ser humano, como se este fato fosse ignorado, já que ocorre a transformação em "mão-deobra para tocar o serviço". Este comentário nos remete a duas questões: a primeira de como o curso fica identificado como o lugar privilegiado para as questões humanas/subjetivas e a outra é do entendimento da Residência como um lugar para trabalhar dentro de 
uma instituição comprometida com a assistência, mas nem tanto com a formação e o ensino.

Cabe, ainda, trazer para a discussão o recente movimento de humanização nas práticas de saúde, que marca o final da década de 90 em nosso país, consubstanciado por proposições políticas governamentais referentes a este tema na atenção à saúde. O Programa Nacional de Humanização da Assistência Hospitalar (PNHAH), lançado pelo Ministério da Saúde, em 2001, constituiu um marco importante neste sentido, na medida em que apresenta como proposta "um conjunto de ações integradas com o objetivo de alterar os padrões de assistência aos usuários no ambiente hospitalar público" (FORTES, 2004, p. 33). Este programa pretendeu destacar a necessidade de uma mudança cultural neste tipo de ambiente de trabalho, pressupondo que um atendimento mais humanizado poderia resultar em maior qualidade e eficácia às ações empreendidas, bem como "incorporou a preocupação com a valorização, a capacitação e o desenvolvimento dos trabalhadores do setor saúde, dos encarregados da tarefa do cuidar" (p.34), enfatizando, inclusive, a formação educacional dos profissionais de saúde, com vistas a incorporação de valores e atitudes de respeito à vida humana.

Este ponto incide diretamente sobre o interesse central de nossa pesquisa, na medida em que propomos uma modalidade de ensino, calcada na discussão, reflexão e interlocução, que procura sustentar o foco no profissional e nas vicissitudes de sua prática.

\subsection{DSC9}

"É gratificante ter um momento nessa vida corrida que é a Medicina (Pediatria, em especial) para sentar e conversar sobre assuntos muito pertinentes em nossa vivência diária. Mais do que entender melhor as relações entre os nossos pacientes, seus pais e o meio que os cercam, o curso nos permitiu conhecer melhor a nós mesmos: cada 
um em separado e o grupo como um todo. Em uma das atividades em que se perguntou de onde surgira a idéia de cada um partir para a área médica e, o que parecia apenas mais uma das centenas de vezes que descreveríamos nossos motivos e vocações, foi na verdade, um momento de profundas revelações, tanto a respeito dos meus colegas como (para minha surpresa) sobre mim mesma. Vejo agora que meu bem-estar é indispensável na tentativa de estabelecer qualquer vínculo com meus pacientes e seus responsáveis, desde a relação mais curta, como numa consulta de pronto-socorro, até o maior vínculo, necessário para um bom acompanhamento ambulatorial. Os benefícios serão levados para o resto da residência e, mais importante, para nossas vidas."

Conforme destacado na discussão do relato anterior, a avaliação do curso pelos residentes permite revelar um importante desdobramento para a questão da discussão da humanização da formação profissional, qual seja, a oportunidade oferecida no processo de formação para cada um dos residentes refletir um pouco sobre si mesmo. Cabe lembrar que toda a ênfase dada aos aspectos subjetivos deste encontra-se atravessada pelo exercício profissional e as particularidades envolvidas no papel do médico. Parece inequívoca a noção da importância do bem-estar do médico para o desempenho das suas habilidades e competências, tal como foi percebida, assim como para a vida pessoal. Entretanto, não parece haver limites claros no alcance que a abordagem dessas questões pode suscitar em cada um.

\subsection{DSC10}

"Infelizmente, muitos de nós somos obrigados a tirar férias durante o estágio de Pediatria Comunitária e saímos perdendo, pois essas discussões são únicas nesta fase de nossa formação, diferentemente de ambulatório, enfermaria e PS, onde é possível a reposição. Acabei 
perdendo 3 temas por causa das férias, quando voltei, senti bastante a falta de alguns conceitos que tinham sido trabalhados naqueles dias, principalmente sobre o desenvolvimento da subjetividade, pois muito se falou sobre isso nas semanas que se seguiram e até agora estou tentando recuperar esta perda. Sugiro que haja um meio de que isso não ocorra nas outras turmas, pois acabamos perdendo uma boa parte do programa."

Dentre as avaliações, observou-se a ocorrência de comentários acerca da obrigatoriedade de férias durante o estágio de Pediatria Comunitária. Damos relevância a este fato pois assinala a forma como é feita a estruturação do Programa de Residência, determinando os períodos de férias em determinados estágios, em detrimento de outros. Parece-nos relevante destacar a importância que foi dada à perda das aulas como um fato irreversível, mas que poderia ser modificado.

\section{Avaliação do conteúdo}

Neste ítem, agrupamos os discursos que foram construídos a partir das considerações realizadas acerca do conteúdo do curso. Há comentários sobre a escolha dos temas e dos textos e os aspectos mais significativos quanto aos tópicos que foram abordados ao longo da atividade. Consideramos esta distinção importante porque permite analisar um aspecto formal do curso que visa também o contato com novos conceitos, a apreensão e a elaboração dos mesmos.

\subsection{DSC1}

"No início, a leitura dos textos foi difícil, porém com a evolução dos temas e à medida que as discussões foram avançando pude me familiarizar e ficar mais a vontade, tendo, inclusive, maior intimidade 
com os assuntos. Não estava habituado a fazer este tipo de leitura e no início do estágio, eu achava um pouco difícil acompanhar o raciocínio seguido, principalmente por nunca ter entrado em contato com o assunto, mas este se tornava mais fácil de ser compreendido a cada texto e tudo começou a fluir melhor. Como o objetivo do curso não era esgotar os temas, mas introduzir novos pensamentos e informações em nossas reflexões, os textos abordados foram necessários para homogeneizar o conhecimento."

Houve uma ocorrência numericamente importante em relação aos comentários quanto à dificuldade inicial em lidar com os textos, seu vocabulário e sua lógica. Isto se refletiu também nas discussões iniciais que causaram estranheza devido a uma estruturação não habitual de pensamento e de raciocínio.

Entretanto, na medida em que a coordenação assumiu o papel de facilitar o entendimento, promover e incentivar a reflexão, os residentes sentiram-se mais à vontade em colocar o que pensavam, suas dúvidas e questionamentos, conforme pôde ser observado neste discurso-síntese. Mais do que um trabalho de esclarecimento quanto ao que o autor quis dizer, procuramos enfocar e explicitar as condições de produção daquele tipo de conhecimento. Este eixo norteou toda a nossa tarefa, pois a cada tema procuramos delimitar um campo de análise a partir da contextualização do assunto a ser tratado. Foi importante levantar os diferentes funcionamentos discursivos do material proposto, já que utilizamos artigos científicos, reportagens, falas proferidas em mesas-redonda etc, propositalmente. Nosso intuito foi o de favorecer a construção de um entendimento próprio (de cada residente) a partir de variadas interpretações sobre o mesmo tema.

\subsection{DSC2}


"Os textos parecem ter sido escolhidos de uma forma especial e, em sua grande maioria, tiveram propriedade nos assuntos abordados, nos suscitando questionamentos, reflexões e críticas. O esquema proposto - leitura, apresentação e discussão - é adequado e as dúvidas são elucidadas pelas excelentes discussões em sala."

Nota-se claramente como os textos puderam ilustrar e sustentar as discussões em sala, considerando as observações do discurso precedente (2.1.DSC1) que complementa a consideração de pertinência apontada pelas avaliações.

\subsection{DSC3}

"Considero que saí bastante enriquecido deste curso, tanto no que diz respeito aos conceitos quanto à compreensão dos pacientes e da minha relação com eles. Meu conhecimento evoluiu muito: "aprendi" a ler textos que não tem aquele formato que estamos acostumados, recebi muitas informações novas que são muito úteis no dia-a-dia (como a formação do sujeito, um tema que após o estágio considero essencial na formação de um pediatra!). As discussões mudaram meu modo de pensar, "abrindo minha cabeça", me levaram a fazer reflexões que nunca havia pensado e a formar algumas opiniões."

Este aspecto relativo aos ganhos cognitivos já foi apontado no ítem de Avaliação geral, quando analisamos o discurso sobre o aprendizado (1.5.DSC5). Entretanto, consideramos interessante desdobrar um pouco mais este nível e não restringi-lo apenas ao campo conceitual, teórico. Levantamos como os tópicos mais apontados pelas avaliações: "a compreensão dos pacientes e minha relação com eles", o aprendizado da leitura de textos (diferente da formatação científica), o contato com informações novas e úteis e finalmente a possibilidade de refletir sobre assuntos "novos". 
Podemos considerar, a partir deste fragmento, a oportunidade de reflexão que nossa proposta enseja apontada como inusitada no contexto de uma formação marcadamente tecnicista, objetiva e pragmática. Podemos supor que os conteúdos trabalhados tanto na graduação como na residência obliteram, de forma contundente, o próprio ato de reflexão tanto da condição do médico como do paciente enquanto sujeitos.

\subsection{DSC4}

"Foi uma grande oportunidade para refletirmos um pouco sobre as mudanças atuais de comportamento, estrutura familiar e toda a influência dessas mudanças sobre o desenvolvimento infantil, o que não encontramos em livros-textos. O curso teve um conteúdo muito bom e é extremamente importante por trazer para discussão temas como o desenvolvimento na óptica da Psicanálise e da Psicologia. Foi interessante discorrer sobre Édipo e sua influência no crescimento das crianças, a importância da relação mãe-filho, a estruturação do sujeito e como seus desvios se mostram como sintomas, muitas vezes, referidos nas consultas. Espera-se que um pediatra possa oferecer mais do que uma visão leiga do assunto e o curso é bemsucedido em nos dar embasamento para tal."

Nesta narrativa, vemos sublinhado o aspecto do conteúdo que não se localiza em livros, manuais etc, mas que foi construído no decorrer da atividade, a partir dos intercâmbios produzidos no grupo.

Um tema central na montagem do curso foi, com efeito, percebido como tal que é a concepção de estruturação subjetiva, baseado na teoria psicanalítica do Complexo de Édipo. Vale dizer que a referência sobre as teorias psicológicas/psicanalíticas também foram destacadas quanto aos temas como o vínculo mãe-filho e a abordagem dos sintomas por este viés, tão distinto da concepção médica. Foram reconhecidos a capacidade de embasamento e de uso 
que estes operadores podem fornecer para o entendimento da subjetividade, por parte do residente, o que é reconhecido, em vários discursos-síntese já analisados como parte importante do "instrumental" que o médico deveria receber para bem exercer sua prática profissional.

\subsection{DSC5}

"Pude esclarecer várias questões, principalmente relacionadas à Psicanálise, as quais antes me pareciam estranhas e até mesmo absurdas. Isso devido à falta de conceitos e definições, que antes acabavam sendo interpretadas de maneira errônea. Clareou bastante para mim porque realmente eu não entendia Freud e agora vejo que há sentido em algumas coisas que ele afirmava. Foi pouco, mas o suficiente para acabar com alguns dos pré-conceitos que eu tinha."

A adoção da Psicanálise como um dos eixos orientadores do curso foi explicitada desde o seu início, instigando a curiosidade dos residentes, na medida em que esta interpretação foi colocada ao lado de outras (antropológica, biológica, política etc). Foi possível perceber no contato com os inúmeros grupos uma resistência inicial, trazida sobretudo de um contato prévio bastante superficial durante a graduação, na sua grande maioria. No entanto, parece ter sido suficiente para despertar sentimentos de rejeição e desprezo frente a teorização psicanalítica. Conforme o discurso acima, notamos uma mudança importante de postura frente a esta corrente, devido ao contato mais aprofundado e consistente com as formulações que a sustentam.

Vale destacar além da questão do conteúdo, que a estratégia pedagógica utilizada de discussão e identificação dos problemas 
vividos pelos residentes em seu cotidiano adquiriu sentido e importância, tornando a experiência bastante produtiva.

\subsection{DSC6}

"A saúde mental da criança é um segmento que deve ser pensado e estudado por todo pediatra que deseje clinicar, usando uma abordagem global e integral à saúde da criança. Para isso é importante se conhecer e estudar o psiquismo da criança e daqueles que sobre ela atuam, já que os primeiros anos de vida são básicos para a estruturação psíquica do indivíduo. As condutas e as orientações que possam assegurar uma correta higiene mental são mais importantes na vida infantil do que na vida adulta, além disso, deve-se considerar que atualmente, enfrentamos cada vez mais na prática clínica, problemas desta ordem."

Finalmente, nesta última narrativa temos a oportunidade de discutir a questão da Saúde Mental da criança como essencial para a concepção global da criança e a conseqüente abordagem integral do pediatra. Além disso, temos uma referência à própria clínica que demanda esse tipo de conhecimento devido, inclusive, à expressiva ocorrência de problemas trazidos ao pediatra relacionados a esfera do comportamento, orientações à família e assim por diante.

Retomando o percurso que fizemos no capítulo dedicado ao tema da Saúde Mental da criança em nossa pesquisa, pudemos apontar a importância da mudança de concepção de higiene mental para saúde mental, no final da década de 1940. A partir da criação da Organização Mundial da Saúde, em 1948, no contexto de acontecimentos políticos de grande impacto que promoveram a necessidade de um resgate dos valores humanos, observamos a emergência de um novo paradigma no campo da saúde, que pudesse transcender a esfera biológica. 
Ao se elaborar um novo conceito de saúde como a promoção de um estado de bem-estar completo, físico, mental e social e não mais como ausência de doença, buscava-se a articulação com o surgimento de uma nova mentalidade que pudesse alicerçar um projeto de recuperação da dimensão do humano, simbolicamente representado pela Declaração Universal dos Direitos Humanos.

Neste sentido, notamos um marco importante no campo da saúde, na medida em que dá visibilidade à questão da Saúde Mental, buscando a articulação desta com a Saúde Física. Nesta mesma época, temos os já mencionados movimentos de recomposição da prática médica - Medicina Integral e Medicina Preventiva - como elementos decisivos para a compreensão do indivíduo em sua totalidade biopsicossocial. Vale lembrar a pertinência dos conhecimentos de outras disciplinas oriundas das Ciências Humanas, ao revelaram de forma crítica o excessivo reducionismo representado pelo enfoque biológico no processo saúde-doença.

O aspecto que procuramos destacar, problematizar e elaborar como proposta de ensino em nossa pesquisa, traduzido como a importância da subjetividade na prática médica e explicitado ao longo deste trabalho, traz no seu bojo, de maneira inequívoca, o resgate da concepção integral da criança.

\section{Avaliação da dinâmica e metodologias empregadas}

Dentro desta tema, interessa-nos descrever e discutir os aspectos relacionados aos movimentos do grupo ao longo do processo de construção da atividade, considerando a interação entre os membros, a participação, a divisão de tarefas, etc. Por outra parte, cabe-nos também considerar como foram avaliados nossos métodos, ou seja, os meios utilizados para a consecução da proposta de ensino. 


\subsection{DSC1}

"Foi essencial termos um tempo dedicado para parar, refletir sobre as diversas questões e poder compartilhar opiniões e experiências com o grupo. É um curso dado de forma muito dinâmica, em que todos interagem durante a aula, e as diferentes opiniões podem ser expressas e entendidas. Em algumas situações, antes do início das discussões, eu apresentava determinada opinião e, após ouvir o que cada um entendia por determinado tópico, pude mudar meus conceitos. Além de nossas opiniões, pudemos expor também nossos sentimentos. Fomos tomados, durante as discussões, por momentos de raiva, indignação, conivência, entre outros sentimentos mais difíceis de serem nominados. Gostei também do espaço dado para a discussão das angústias, que nós, residentes, passamos no consultório e na relação com os pacientes. Foi importante saber a opinião e os sentimentos de outras pessoas sobre seus pacientes. Outro ponto positivo é a possibilidade de nós expressarmos os sentimentos para com a etapa da vida em que estamos atravessando, em que tudo era novidade e trazia certos conflitos. Foi reconfortante notar que meus colegas passavam por conflitos parecidos, e que não estava sozinho. Permitiu um desabafo e uma orientação do caminho a seguir."

Observa-se, a partir deste fragmento, três níveis diferentes, que apontam inequivocamente na direção de um processo de transformação e mudanças. O primeiro refere-se ao potencial contido na experiência de discussão e de debate dos assuntos, promovendo trocas significativas. Parece evidente a motivação provocada pelos questionamentos, em que cada um dos membros se sente convocado a participar. Isto acarreta, em nosso entendimento, um segundo desdobramento que é a oportunidade de enriquecer e ampliar através das informações a bagagem cognitiva dos residentes. E finalmente, um terceiro campo relacionado aos afetos, também foi contemplado 
muito mais para exemplificar e demonstrar sua importância no estabelecimento da relação com o paciente e sua família do que para apontar questões particulares, já que não há qualquer viés terapêutico nessa modalidade de trabalho com o grupo. Pudemos constatar que o tipo de estratégia pedagógica utilizada proporcionou a oportunidade dos residentes se colocarem de forma integral, revelando sua pertinência para o processo de ensino-aprendizagem.

Cabe lembrar que a ênfase atribuída à formação técnica durante a graduação e mesmo depois dela, referida em relatos anteriores "apaga" de forma contundente o aspecto subjetivo presente nos embates que os jovens médicos vivenciam nas dificuldades tanto para se relacionar com seus pacientes, como para compreenderem os limites de sua atuação, proporcionando experiências muito angustiantes e aparentemente "sem saída". As discussões e os encaminhamentos apontados sugerem uma via de trabalho a partir do entendimento e da elaboração dos conflitos e se constituem como ferramentas úteis para a resolução desse tipo de impasse.

\subsection{DSC2}

"No primeiro dia do estágio me foi dada a oportunidade de, pela primeira vez desde o início da residência, parar para ouvir um pouco meus colegas de equipe, saber um pouco mais sobre a vida, a história e as peculiaridades de cada um. Apesar de convivermos muitas horas juntos durante o ano, ainda existem coisas que desconhecemos dos colegas e talvez se soubéssemos mais uns sobre os outros poderíamos tornar a residência mais "leve" e mais solidária, possibilitando um melhor vínculo entre nós. Sem dúvida, foi uma prática de relação entre as pessoas! Um ganho inestimável, a meu ver." 
A aposta contida no trabalho em grupo sugere um efeito bastante revelador, que é a oportunidade de ouvir mais e melhor cada um dos colegas com quem se estabelece uma convivência diária. O curso é visto, assim, como uma oportunidade de fortalecer os vínculos entre os seus membros e, sem dúvida, enriquecer os relacionamentos, para além da divisão de tarefas e responsabilidades, próprias do funcionamento da Residência.

Este tipo de técnica pedagógica empregada na atividade aponta para a abertura de um espaço fundamentado na interlocução, propiciando uma "prática de relação entre as pessoas" rica e nova, já que esta modalidade não parece ser utilizada durante a formação médica, de uma maneira geral.

Vale comentar que embora os residentes constituam um grupo, isto se traduz num conjunto de pessoas em que estas ocupam o lugar de quem "recebe" os conteúdos, de forma passiva, devido ao tradicional ensino de aulas ou práticas. Nossa proposta parte do pressuposto da importância do intercâmbio de experiências como um ponto básico para o trabalho.

\subsection{DSC3}

"Achei o método de discussão muito cansativo, pois uma pessoa falando por mais ou menos quatro horas torna-se pouco produtivo."

\subsection{DSC4}

"Acho que a metodologia empregada foi interessante, pois muitas das minhas dúvidas que surgiam durante a leitura, foram esclarecidas no momento da discussão. Foi possível, também, resgatar os assuntos discutidos anteriormente, reforçando os conceitos." 
Consideramos interessante agrupar estes dois fragmentos para fecharmos este tema, pois cabe destacar a ocorrência do comentário em uma única avaliação quanto à análise da metodologia empregada, uma vez que diverge significativamente das demais. Neste caso, para um residente a percepção do curso foi a de que apenas a coordenadora se colocava, não tendo reconhecido a participação do grupo como essencial para o desenrolar da atividade.

Por outro lado, na última narrativa fica referido nas avaliações o comentário sobre o método utilizado, visto como positivo, já que favorece o esclarecimento de dúvidas e a retomada dos conceitos trabalhados. Acrescenta-se, também, o reconhecimento das dificuldades quanto aos temas e aos textos, trazidos como estranhos ao universo de formação tradicional, além da demanda de exposição de questões, opiniões etc, próprias ao trabalho em grupo, mas que pôde ser superado e bem aproveitado.

\section{Avaliação da Coordenação}

Neste ítem, que apresenta observações feitas quanto à coordenação da atividade, identificamos aspectos considerados relevantes sobre este tema, dado o papel estratégico a ser desempenhado pelo coordenador.

\subsection{DSC1}

"Creio que o curso é conduzido por uma profissional muito bem capacitada, não-autoritária e interessada a respeito de qualquer assunto trazido às discussões. A coordenadora teve um papel fundamental, ajudando-nos a refletir sobre os temas, trazendo exemplos, pensamentos e conclusões de maneira muito inteligente e 
objetiva. Além do mais, ela consegue expor com clareza suas idéias e de maneira interessante."

\subsection{DSC2}

"Considerei importante a disponibilidade da coordenadora em aceitar sugestões, conforme a demanda dos residentes, como foi o caso do tema "adoção"."

Notamos a importância da coordenação na condução da atividade, que foi apontada como positiva, já que foi possível estabelecer um bom diálogo com o grupo, captar as suas necessidades e expor as conceituações com clareza e objetividade, ocupando uma função de facilitadora para a emergência de questões e discussões.

Com efeito, o segundo fragmento aponta a importância do grupo ser escutado pela coordenação, contemplando melhor suas necessidades e confirmando a existência de uma abertura para que isto tivesse ocorrido. Neste sentido, o espaço pedagógico construído foi de interlocução.

\section{Sugestões}

Observamos, no tratamento e na análise do material, uma quantidade bastante expressiva de sugestões de temas, de modos de funcionamentos e alguns pedidos. Agrupamos todos estes recortes neste tema, que poderá ser utilizado, sem dúvida alguma, como fonte para o aprimoramento de nosso trabalho.

\subsection{DSC1}


"Gostaria de fazer uma sugestão: ao invés de uma pessoa ficar responsável por um tema, duas pessoas poderiam ser incumbidas, talvez a apresentação flua melhor."

É sugerida uma mudança na forma da apresentação dos textos, cuja responsabilidade fica a cargo de um residente, previamente combinado, passando para duas pessoas com intuito de engajar mais componentes do grupo para a tarefa.

\subsection{DSC2}

"Sugiro inserir como base para discussão, além dos textos, um roteiro de perguntas que enfoque pontos mais fundamentais sobre $o$ tema abordado. Outras atividades como simulações, vídeos, reportagens e questionários sobre o tema também aprimorariam os debates."

Através deste recorte, notamos que a proposta de discutir em grupo pode ser enriquecida com a utilização de outros materiais, como vídeos, ou mesmo métodos diferentes como simulações. Fica evidenciada a necessidade de utilização de outros meios para o aprofundamento dos temas, demonstrando que a participação dos membros do grupo, sob forma de expressão de questionamentos, opiniões, tal como ocorreu, não contempla inteiramente o processo de aprendizagem. Este fato pode ser explicado pela complexidade com que determinados temas foram abordados, daí a sugestão de roteiros de perguntas, na forma de "estudo dirigido" facilitando a apreensão das idéias centrais contidas nos textos.

\subsection{DSC3}

"Acho que também podem ser discutidos métodos práticos de consulta de crianças com problemas psicológicos. Por exemplo, 
depressão, fracasso escolar, psicoses, dificuldade de alimentação poderiam ser ilustrados com discussão de casos clínicos. Isto nos ajudaria a identificar psicopatologias pediátricas ou como lidar na suspeita das mesmas. O que eu devo fazer? Encaminhar? Para quem? Às vezes, fica difícil trazer casos que sejam compatíveis com o que está sendo abordado. Gostaria de deixar como sugestão que você trouxesse para a discussão alguns casos que considerasse ilustrativos e assim suprir o nosso maior anseio que é a aplicabilidade clínica do que aprendemos."

Neste ítem, foram observados muitos comentários e sugestões sobre a necessidade de discussão de casos com propostas de intervenção sobretudo relacionados aos casos de crianças com problemas psicológicos. Certamente, acolher esta sugestão implicaria mudanças quanto aos objetivos de nossa proposta. No entanto, a ocorrência de falas neste sentido foi tão expressiva que merece algum encaminhamento, eventualmente, em outro espaço do Programa de Residência que pudesse sistematizar tais discussões. Tal sugestão, entretanto, demonstra a necessidade de aprofundamento de discussões de casos em que os aspectos psicológicos sejam explicitados, tal como desenvolvemos em nossa proposta, demonstrando sua importância.

\subsection{DSC4}

"Senti falta de temas como o desenvolvimento psicossocial da criança, que é importante para avaliar e identificar precocemente os casos que necessitam de trabalho específico, bem como as doenças ou manifestações psicossomáticas, bastante prevalentes na prática pediátrica e onde existe dificuldades quanto à abordagem."

Temos, neste fragmento, um desdobramento do anterior (5.3. DSC3) diretamente relacionado à demanda de discussões de casos 
clínicos, ou seja, formas práticas de avaliação e intervenção, onde foram sugeridos dois temas específicos: desenvolvimento psicossocial da criança e psicossomática.

Observamos, portanto, a relevância do curso na medida em que descortina a relação entre a prática pediátrica e as contribuições que o campo da Psicologia e Psicanálise podem oferecer para a formação médica. Revela também a enorme amplitude da Pediatria, pela complexidade de problemas que enseja, e a necessidade de outros conteúdos, como o que trabalhamos, tanto na graduação como na residência para contemplá-los.

\subsection{DSC5}

"É pena que o curso seja tão curto, restrito apenas ao estágio de Pediatria Comunitária, já que o tema é muito amplo e mereceria ser estendido por toda a residência. Tenho interesse, inclusive, em estudar mais sobre Freud, Piaget etc. $O$ contato com a Psicologia/Psicanálise foi muito bom, e gostaria de participar periodicamente desse tipo de discussão."

Nesta narrativa, surge o desejo de prolongar esse tipo de trabalho, com a sugestão de torná-lo regular, ao longo do Programa de Residência e não restrito a um estágio. Esta atividade é percebida como necessária e útil e consideramos duas alternativas possíveis: como um trabalho que pode ser articulado a outros estágios, de acordo com suas particularidades, ou como uma atividade que pode ocorrer de maneira independente, haja vista a riqueza de assuntos a serem trabalhados. Fica explicitado, portanto, a importância da utilização de novos referenciais para a formação global do médico, não somente na prática pediátrica, o que aponta, mais uma vez, para a necessidade de atualização da formação médica em nível de graduação e da própria residência. 


\subsection{DSC6}

"Acho que este curso teve uma função extra-programação que foi a de amparar os residentes, ouvindo e discutindo sobre os assuntos que nos afligem. Isto deveria se estender ao longo de todo ano - com objetivo não apenas de abordar os aspectos psíquicos das crianças, mas também dos residentes. Nós passamos por muitas situações e não encontramos espaço para discuti-las. Sugiro que isto seja feito em grupo - dividir as angústias e dúvidas - afinal, é importante cuidarmos da nossa saúde mental, certo?"

Esta sugestão permite demonstrar um dos efeitos promovidos pela atividade desenvolvida que foi a possibilidade de um trabalho específico com os residentes. Isto demandaria a criação de um espaço de troca de experiências, para abordagem dos aspectos psíquicos envolvidos na prática médica, que merecem ampla discussão, de acordo com a percepção expressa nas avaliações. Novamente, este tipo de demanda exige a estruturação de uma atividade inserida no Programa de Residência, com objetivo específico de acolhimento das questões apontadas, sem propósitos necessariamente terapêuticos para o médico, mas que propicie um espaço de interlocução e troca de experiências.

Revela-se, portanto, que o tipo de formação oferecida na graduação e mesmo na residência pressupõe a existência de um médico "humanizado" de forma naturalizada, na medida em que não se prevê espaços de trabalho para o desenvolvimento e discussão destas questões. Conforme já referimos, não se trata de transformar os problemas inerentes à prática, sobretudo às dificuldades na relação médico-paciente em questões psicológicas particulares do médico. Isto traz como conseqüência o falso entendimento de que este deve ser encaminhado para um trabalho específico, como a psicoterapia, por exemplo. A despeito de que isto pode ter sua 
pertinência em alguns casos, os relatos apontam para a necessidade de uma outra abordagem que dê conta da formação do médico, considerando que a complexidade de sua prática envolve considerar igualmente que sua formação ultrapassa a mera aquisição de conhecimentos e práticas científicas e tecnológicas.

A reflexão atual sobre a humanização do atendimento em saúde revela a necessidade do resgate da condição de sujeitos em interação cujo "encontro" se dá no processo de construção da relação médicopaciente. Temos, aqui, concretizada uma verdadeira relação, não somente profissional, mas principalmente social, ética e humana. Neste sentido, o presente trabalho permite não somente uma reflexão sobre a atividade desenvolvida, mas sobretudo o processo de formação do médico. 


\section{Considerações finais}

Caberia, ainda, tecermos alguns comentários sobre os resultados de nossa pesquisa, retomando os pontos principais que animaram este empreendimento no qual fundamentamos nosso trabalho de ensino de Saúde Mental da Criança no contexto da Residência Médica em Pediatria.

Tomamos como pressuposto a necessidade e a importância de incluir os aspectos subjetivos da criança e da família na prática pediátrica, de modo a contemplar uma visão global (ou biopsicossocial) do paciente, tal como é preconizada pelo ideário da instituição em foco. No entanto, ressalta-se que tal princípio não se viabiliza na prática, na medida em que ocorre um inequívoco privilégio dos fatores biomédicos sobre os demais níveis.

Deste modo, procuramos delinear uma série de questionamentos para esboçar nossa pesquisa, cujo grande interesse consistiu em resgatar os movimentos históricos que pudessem nos fornecer elementos para a compreensão do processo de construção do campo da saúde da criança. A partir do esboço deste universo mais recortado, partimos para a descrição e a análise da atividade de ensino cuja questão central poderia ser sintetizada como: qual é a importância da subjetividade no ensino da Pediatria?

Lembremos, inicialmente, que os tópicos relativos aos aspectos subjetivos da criança e da família adquiriram sustentação através de uma atividade inserida em um estágio num momento privilegiado da formação do médico, qual seja, o período da Residência.

Destacamos o papel fundamental desta fase na qual o jovem médico encontra-se inserido em serviços de saúde que buscam a integração da assistência à população com a prática de ensino e pesquisa, características do ambiente universitário no qual se insere nosso trabalho. Retomemos, também, o que pode ser considerado uma característica marcante do médico e que o distingue de uma 
série de outras profissões, que é o aprendizado de atitudes que regem sua conduta para a resolução de problemas em que aspectos subjetivos deste, do paciente e da família têm uma papel fundamental que não podem ser desprezados.

A combinação de conhecimentos, habilidades e sentimentos definem a conduta médica e pode variar de acordo com o paciente, a partir de outros aspectos relevantes de ordem econômica e social. De tal forma, que temos a perspectiva do desenvolvimento da prática médica pautada em aquisições cognitivas aliada ao aprimoramento de habilidades e de vivências de atitudes. Acrescentamos, a partir de nossa proposta um outro elemento que é a possibilidade de refletir sobre o que é vivido de forma orientada, visando o aguçamento de um certo senso crítico.

Pudemos constatar em nossa pesquisa que o ensino médico caracterizou-se no decorrer do século XX, tendo o Relatório Flexner como marco, pelos ideais objetivantes, de caráter racional marcado pelo positivismo. Este processo desencadeou um enorme incremento não somente das especialidades impulsionado pela pesquisa biológica com bases científicas, mas também pelo crescimento dos suportes tecnológicos como recursos privilegiados ao exercício da Medicina. Como conseqüência, observamos uma fragmentação do objeto individual que rompe com uma visão globalizadora deste mesmo objeto.

Por outro lado, destacamos em nosso trabalho a importância dos movimentos que caracterizaram a recomposição da prática médica ao longo do século passado. A problematização mais importante trazida pelos fundamentos que constituíram a Medicina Integral, Preventiva e Comunitária parece-nos ser a busca do descentramento do enfoque biológico e a possibilidade de inclusão do paciente num campo de relações, onde a família passa a adquirir grande importância. O envolvimento do médico em experiência comunitárias, graças ao foco voltado a partir desta visão para os 
grupos vulneráveis imprimiu uma nova ênfase na relação médicopaciente engendrando uma discussão mais ampliada de qual seria a natureza do seu objeto de trabalho.

No entanto, a predominância da medicina tecnológica se manteve, com implicações para a formação do profissional médico. Devemos considerar a relevância de tais movimentos para a prática médica, na medida em que apontam para a impossibilidade de redução do seu conhecimento a uma única disciplina, pois vários conhecimentos convergem para a explicação e abordagem dos fatos inerentes ao processo saúde-doença-morte, daí, portanto, seu caráter interdisciplinar. Outro fator fundamental refere-se à concepção da Medicina como uma prática social e não puramente técnica, conforme pudemos demonstrar a partir dos diferentes movimentos mencionados, sobretudo, com o surgimento da Medicina Comunitária.

Foi possível demonstrar a partir da descrição e análise das avaliações dos residentes que nossos objetivos puderam ser alcançados e foram pertinentes nesta etapa da vida dos sujeitos que elegemos para a pesquisa.

Depreendemos que nossa proposta, tal como foi desenvolvida e descrita nesta pesquisa, ao trabalhar com temas que contemplem problemas comuns e pertinentes para a prática médica, contenha um potencial transformador e produtivo, passível de ser observado nos discursos dos residentes. Lembremos que a articulação do curso com a vivência prática durante esta etapa de formação foi apontada como bastante positiva.

O emprego de uma técnica pedagógica que promove o debate de idéias enriquece e acrescenta informações de forma distinta das aulas expositivas e do uso de manuais, habituais do ensino tradicional. Notamos como este parece ser um aspecto que merece destaque, na medida em que a formação voltada para a técnica produz o efeito de encobrir a subjetividade do médico. Durante o treinamento intensivo em serviço, este se vê às voltas com o 
enfrentamento de inúmeras situações com as quais nâo se sente a vontade para abordar, conforme foi reconhecido pelo levantamento de temas utilizados no curso. Nesta oportunidade, as discussões e os encaminhamentos apontados pela coordenadora abrem uma perspectiva nova que é a de lidar com as demandas trazidas pela família em relação à criança, que podem ser trabalhadas e não "colocadas de lado". Outro aspecto é que o contato com os próprios afetos e a explicitação dos mesmos promovem um entendimento das vicissitudes da relação médico-paciente que pode ser utilizada também com fins práticos. Portanto, a emergência de angústias inerentes ao exercício profissional passa a ser vista não mais como um problema, mas como um recurso operativo. A análise das avaliações permite demonstrar, portanto, que o objetivo relativo à questão da relação médico-paciente foi plenamente alcançado, conforme destacamos na discussão dos discursos, na medida em que propiciou ao residente o trabalho de desenvolvimento de sua capacidade de reflexão e de senso crítico sobre sua ação, sua postura ética e seu papel social, utilizando como eixo para análise a relação médico-paciente, tal como postulamos em nossa proposta.

Vale notar que o objetivo traçado na elaboração da atividade relacionado à articulação das questões subjetivas da criança e da família aos sintomas que são trazidos e a problematização das demandas de intervençaõ e de resolução de problemas como elementos-chave para a a abordagem do pediatra também puderam ser atingidos de forma satisfatória. Os operadores mais referidos para promover o entendimento da subjetividade confirmam a nossa intenção ao oferecermos diferentes estratégias para trabalhá-los, são eles: a concepção da estruturação subjetiva, o Complexo de Édipo, o vínculo mãe-filho e sua relação com o desenvolvimento da criança, a relação médico-paciente e a compreensão do sintoma psicológico. Observou-se, também, a reversão de um certo preconceito em 
relação à teoria psicanalítica, adotada como referencial tanto teórico como clínico, bem como o reconhecimento de sua importância.

Finalmente, é possível afirmar que a questão da Saúde Mental da criança foi considerada essencial tanto para a concepção global da criança como para a abordagem integral por parte do pediatra, pois resgata sua importância na concepção de objeto integral, preconizado pelos movimentos de recomposição da prática médica, que imprimiu uma nova mentalidade às práticas de saúde, conforme desenvolvemos em nossa pesquisa. Lembremos também a expressiva demanda de problemas, orientações e questões relacionadas ao comportamento das crianças por parte das famílias levantadas nos discursos dos residentes, que aponta para a relevância de sua compreensão.

$\mathrm{Na}$ abordagem do tema designado como "sugestões" trazidas pelos residentes quanto à elaboração de espaços semelhantes, onde os aspectos psíquicos pudessem ser contemplados, tanto por parte do entendimento dos sintomas pertinentes à clínica pediátrica, como pela importância de se encontrar encaminhamentos para as dificuldades vividas na relação médico-paciente, pudemos observar que esse tipo de formação aparece como uma demanda relevante. É possível vislumbrar a organização de atividades de caráter teórico para a retomada de teorias do desenvolvimento e psicopatologia, por exemplo, a fim de fundamentar o entendimento dos transtornos comuns da infância. Parece-nos fundamental a discussão sistematizada de casos clínicos, em que também pudessem ser levantados os aspectos da relação médico-paciente, sob coordenação de um profissional da área de Saúde Mental, em outros estágios ainda não contemplados por este tipo de trabalho no contexto da Residência Médica.

Ao desenvolver o trabalho sustentado na importância do aspecto subjetivo em nossa atividade, procuramos não somente destacá-lo e fazer um aprofundamento de sua relevância, mas 
também levantar o quanto nossos propósitos vão ao encontro de um desejo de mudança, que captamos na instituição formadora, nas discussões mais ampliadas sobre a formação profissional do médico, nas necessidades e aspirações da população que busca nossos serviços à procura de qualidade de atendimento e de saúde. Cabe à nós, no contexto da Universidade enquanto produtores de conhecimento formularmos programas e prepararmos os profissionais para que possamos responder de forma mais adequada ao nosso papel, tendo em vista a complexidade com que se reveste a prática médica na atualidade. É imprescindível que criemos condições para a ampliação do entendimento da realidade a que todos estamos submetidos e que as transformações tão desejadas possam, de alguma forma, se realizar. 


\section{Referências}

ADORNO RCF e CASTRO AL. O exercício da sensibilidade: Pesquisa qualitativa e a saúde como qualidade. Saúde e Sociedade 1994;3(2):172-185.

AJURIAGUeRRA J. Manual de Psiquiatria Infantil. São Paulo: Editora Masson do Brasil Ltda; 1983.

ALVARENGA AT. O conceito de risco na área materno-infantil: Considerações teóricas, metodológicas e de aplicação. São Paulo; 1984. [Tese de Doutorado - Faculdade de Saúde Pública da Universidade de São Paulo].

ALVARENGA AT. A Saúde Pública como campo de investigação interdisciplinar e a questão metodológica. Saúde e Sociedade 1994; 3(2):23-41.

ALVES-MAZZOTTI AJ, GEWANDSZNAJDER F. O Método nas Ciências Naturais e Sociais: Pesquisa Quantitativa e Qualitativa. $2^{a}$ ed. São Paulo: Pioneira; 1998.

ARIÈS P. História Social da Criança e da Família. $2^{\text {a }}$ ed. Rio de Janeiro: Editora Guanabara Koogan S.A.; 1981.

ASSUMPÇÃO JR FB. Psiquiatria da Infância e da Adolescência. São Paulo: Livraria Santos Editora; 1994.

ASSUMPÇÃO JR FB, KUCZYNSKI E. Tratado de Psiquiatria da Infância e Adolescência. São Paulo: Editora Aheneu; 2003.

AYRES JRCM. O cuidado, os modos de ser (do) humano e as práticas de saúde. Saúde e Sociedade 2004; v.13, n.3:16-29.

BACHESCHI LA. A Residência Médica. In: Marcondes E, LimaGonçalves E, coordenadores. Educação Médica. São Paulo: Sarvier; 1998. p. 369-73.

BADINTER E. Um amor conquistado: o mito do amor materno. $5^{\mathrm{a}}$ ed. Rio de Janeiro: Nova Fronteira; 1985. 
BERCHERIE P. A clínica psiquiátrica da criança - Estudo histórico. In: CIRINO O. Psicanálise e Psiquiatria com crianças: Desenvolvimento ou estrutura. Belo Horizonte: Autêntica; 2001.

BIRMAN J. Apresentação: interpretação e representação na saúde coletiva. Physis - Rev. Saúde Coletiva 1991; 1(2):7-22.

BOGDAN R, BIKLEN S. Investigação qualitativa em Educação: Uma introdução à teoria e aos métodos. Coleção Ciências da Educação (v.12). Porto: Porto Editora; 1997.

BOLTANSKI L. Puericultura y moral de clase. Barcelona: Ed. Laia; 1974.

CARAFFA RC. Fundação de Assistência à Infância de Santo André 1967-1987: 20 anos de experiência de um sistema de saúde voltado à área materno-infantil. Campinas; 2001. [Dissertação de Mestrado Faculdade de Ciências Médicas da Universidade Estadual de Campinas].

CIRINO O. Psicanálise e Psiquiatria com crianças: Desenvolvimento ou estrutura. Belo Horizonte: Autêntica; 2001.

DEGENSZAJN RD. Teorias sobre o desenvolvimento neuropsicomotor da criança: uma revisão crítica. In: Marcondes E, Vaz FAC, Ramos JLA, Okay Y. Pediatria Básica. Tomo I. $9^{a}$ ed. São Paulo: Sarvier; 2002. p. 36-45.

DIAZ RF, ROGONE HMH. Pediatria e Psicanálise: Reflexões sobre uma prática. In: I Encontro sobre Práticas em Saúde Mental na Infância; maio de 1990; São Paulo: Secretaria do Estado da Saúde; 1991. p. 271-82.

DINIZ EMA, JACOB CMA. Manual de Residência básica. Departamento de Pediatria - Faculdade de Medicina da Universidade de São Paulo; 2001.

DONNANGELO MC, PEREIRA L. Saúde e Sociedade. São Paulo: Duas Cidades; 1976. 
FEUERWERKER LCM. Mudanças na Educação Médica e Residência Médica no Brasil. São Paulo; 1997. [Dissertação de Mestrado Faculdade de Saúde Pública da Universidade de São Paulo].

FLEXNER A. Medical Education in the United States and Canada. A report to the Carnegie Foundation for the Advancement of the Teaching. New York City, 1910.

FORTES PAC. Ética, direitos dos usuários e políticas de humanização da atenção à saúde. Saúde e Sociedade 2004; v.13, n.3:30-35.

FOUCAULT M. Microfísica do poder. $6^{\text {a }}$ ed. Rio de Janeiro: Edições Graal; 1886.

FREUD S. Tres ensaios para una teoria sexual; 1905. In: Obras completas. Madrid: Editorial Biblioteca Nueva; 1981.

FRAGA FILHO C. Ensino médico no Brasil: Análise crítica. Arq Gastroenterol, São Paulo 1988; 25(special issue):26-31.

LACAN, J. Psicanálise e Medicina (conferência de 1966), mimeo.

LEFÈVRE F e LEFÈVRE AMC. Discurso do sujeito coletivo: um novo enfoque em pesquisa qualitativa (desdobramentos). Caxias do Sul: EDUCS; 2003.

LEAVELL HR, CLARK EG. Medicina Preventiva. São Paulo: Editora McGraw-Hill do Brasil, Ltda; 1976.

LEMLE A. A questão da pesquisa nos hospitais universitários. Ciência e Cultura (Revista da SBPC) 1989; 41(4):329-38.

LIMA-GONÇALVES E. Médicos e Ensino da Medicina no Brasil. São Paulo: Edusp; 2002.

MACHADO DVM. Ação psicoprofilática do pediatra. São Paulo: Sarvier; 1979.

MARANHÃO AGK. Situação de Saúde da Criança no Brasil. 2003. <http://www.saudedacrianca.org.br/cis/indic/situacao_de_saude_da_ crianca_de_risco_no_brasil.pdf>

MARCONDES E. Objetivos e organização administrativa do Instituto da Criança (Carta do Embu). Pediat.(S.Paulo) 1979: 1:85-98. 
MARCONDES E. O Departamento de Pediatria da Faculdade de Medicina da Universidade de São Paulo. São Paulo: Sarvier; 1990.

MARQUES MB. Discursos médicos sobre seres frágeis. Rio de Janeiro: Editora Fiocruz; 2000.

MENDES RT. Trabalho e doutrina: os caminhos da prática pediátrica nos Centros de Saúde. Campinas; 1996 [Tese de Doutorado Faculdade de Ciências Médicas da Universidade Estadual de Campinas]

MINAYO MCS. O desafio do conhecimento: pesquisa qualitativa em saúde. São Paulo: Hucitec - Abrasco; 1998.

NOVAES HMD. A puericultura em questão. São Paulo; 1979 [Dissertação de Mestrado - Faculdade de Medicina da Universidade de São Paulo].

OLIVA A. Kuhn: o normal e o revolucionário na reprodução da racionalidade científica. IN: Portocarrero, V. (org.) Filosofia, história e sociologia das ciências. Rio de Janeiro: Editora Fiocruz, 1994.

OPAS/OMS. Relatório sobre a saúde no mundo 2001: Saúde Mental: nova concepção, nova esperança. Genebra; 2001.

PEPE VLE. Breve histórico do percurso de Kuhn: do paradigma ao exemplar. Rio de Janeiro: UERJ/IMS, 1993.

PEREZ EP. A propósito da educação médica. Rev. Saúde Matern. Infant. 2004; 4(1):9-13.

PUGA TF, LEONE C, SANTORO JR M, CUSMINSKY M, FLORES MA. O ensino de Pediatria nas Escolas de Medicina da América Latina ALAPE - OPS 2000. Informe Preliminar. Pediatria (São Paulo) 2000; 22(4): 302-11.

QUEIROZ MS. O paradigma mecanicista da medicina ocidental moderna: uma perspectiva antropológica. Rev. Saúde Públ: 1986; 20:309-17.

REIS AOA, MARAZINA IV, GALLO PR. A humanização na saúde como instância libertadora. Saúde e Sociedade 2004; v.13, n.3: 36-43. 
ROSEN G. Uma história da saúde pública. São Paulo: Hucitec e Editora Unesp; Rio de Janeiro: Abrasco; 1994.

ROUDINESCO E. A família em desordem. Rio de Janeiro: Jorge Zahar Ed.; 2003.

SANTA ROZA E, REIS ES. Da análise da infância ao infantil da análise.

Rio de Janeiro: Contra Capa Livraria; 1997.

SIGAUD CHS. A representação social da mãe acerca da criança com Síndrome de Down. São Paulo; 1997. [Dissertação de Mestrado Faculdade de Saúde Pública da Universidade de São Paulo].

SINGER P, CAMPOS O, OLIVEIRA EM. Prevenir e curar: O controle social através dos serviços de saúde. Rio de Janeiro: Forense Universitária; 1988.

TESSER CD e LUZ MT. Uma introdução às contribuições da epistemologia contemporânea para a medicina. Ciência \& Saúde Coletiva 2002; 7(2):363-72.

VIEIRA MPA, PEIXOTO MRC, KHOY YMA. A pesquisa em história. São Paulo: Editora Ática; 1991.

ZANOLLI ML. A atenção à saúde da criança em Paulínia: um campo de prática da Pediatria Social. Campinas; 1999. [Tese de Doutorado Faculdade de Ciências Médicas da Universidade Estadual de Campinas]. 


\section{ANEXO 1}

\section{PROGRAMA: SAÚDE MENTAL DA CRIANÇA (2003/04) \\ RESPONSÁVEL: RAQUEL DIAZ DEGENSZAJN}

Primeira aula: Apresentação do grupo e do trabalho

\section{Tema 1: A criança e a família na atualidade}

\section{A constituição subjetiva da criança}

Referências: Moraes, MLQ. A estrutura contemporânea da família. In: Comparato, MCM e Monteiro, DSF (orgs.). A criança na contemporaneidade e a psicanálise. Vol. 1. São Paulo, Casa do Psicólogo, 2001.

Kehl, MR. Lugares do feminino e do masculino na família. In: Comparato, MCM e Monteiro, DSF (orgs.). A criança na contemporaneidade e a psicanálise. Vol. 1. São Paulo, Casa do Psicólogo, 2001.

Gomes, FZ e Adorno, RCF. Crescimento e desenvolvimento na prática dos serviços de saúde. Revisão histórica do conceito de criança. Rev. Saúde Públ., S. Paulo, 24 (3): 204-11, 1990.

Pellegrino, H. Pacto edípico e pacto social. Folhetim, Folha de S.Paulo, 11/09/1983. 


\section{Tema 2: A psicopatologia e as novas formas de subjetivação}

Referência: Birman, J. A psicopatologia na pós-modernidade. In: Mal-estar na atualidade. Rio de Janeiro, Civilização Brasileira, 1999.

\section{Tema 3: A depressão}

Referências: Kehl, MR. Uma existência sem sujeito. Mais!, Folha de S.Paulo, 26/01/2003.

Pessotti, I. Para compreender a vida dura. Mais!, Folha de S.Paulo, 26/01/2003.

Reis, RLR e Figueira, ILV. Transtorno depressivo e suicídio na infância e adolescência. Pediatria Moderna. Vol.XXXVIII, n. 6, junho de 2002.

Calligaris, C. O direito à tristeza. Revista da Folha, 02/05/2004.

\section{Tema 4: A violência e a Saúde Pública}

Referências: OMS. Violência - um problema de saúde pública. In: Relatório sobre violência e saúde. Genebra, 2002.

Assis, SG; Minayo MC e Santoro Jr. Violência e maustratos contra crianças e adolescentes: velho problema com novas faces. In: Waksman, RD e Gikas, RMC (orgs.).Segurança na Infância e Adolescência.(Série Atualizações Pediátricas - Sociedade de Pediatria de São Paulo). São Paulo, Ed. Atheneu, 2003.

Lima, CR. Vínculo mãe-filho e a prevenção de acidentes. In: Waksman, RD e Gikas, RMC (orgs.).Segurança na Infância e Adolescência.(Série Atualizações Pediátricas - Sociedade de Pediatria de São Paulo). São Paulo, Ed. Atheneu, 2003.

Falcão, J. O Brasil ilegal. Folha de São Paulo, $12 / 02 / 2004$. 


\section{Tema 5: A criança e a mídia}

Referências: Baitello Jr, N. A mídia e a sedação das imagens. In: Comparato, MCM e Monteiro, DSF (orgs.). A criança na contemporaneidade e a psicanálise. Vol. 2. São Paulo, Casa do Psicólogo, 2001.

Ceccarelli, PR. Os efeitos perversos da televisão. In: Comparato, MCM e Monteiro, DSF (orgs.). A criança na contemporaneidade e a psicanálise. Vol. 2. São Paulo, Casa do Psicólogo, 2001.

Bucci, E. A entrada precoce da criança no mundo do consumo. In: Comparato, MCM e Monteiro, DSF (orgs.). A criança na contemporaneidade e a psicanálise. Vol. 2. São Paulo, Casa do Psicólogo, 2001.

Superligados na TV. Folha de São Paulo, 17/10/2004.

\section{Tema 6: 0 fracasso escolar}

Referência: Degenszajn, RD; Roz, DP; Kotsubo, L. Fracasso escolar: uma patologia dos nossos tempos? Pediatria (São Paulo), vol. 23, n.1, 2001.

\section{Tema 7: A adoção}

Referência: Di Loreto, ODM. Da adoção (e dos erros do pensar) ou Dos erros de pensar (e da adoção). Mimeo.

\section{Tema 8: A relação médico-paciente}


Referências: Rios, IC. Relação médico-paciente - Tempos de pasteurização da subjetividade. Ser médico. Ano II, n.9

Alves, R. O médico à procura do ser humano. Ser médico.

Siqueira, JE. Bioética, Tecnociência e impacto nos serviços de saúde. In: Fortes PAC e Zoboli ELCP. Bioética e saúde pública. São Paulo. CUSC/Loyola, 2003.

Última aula: Encerramento

Entrega dos textos 


\section{Pesquisa: “Pediatria e Saúde Mental da Criança: Uma experiência de ensino na Residência Médica"}

Como parte de minha dissertação de Mestrado, na Faculdade de Saúde Pública da Universidade de São Paulo (USP), estou realizando uma pesquisa relacionada ao ensino na Residência Médica em Pediatria da Faculdade de Medicina da USP (FMUSP). O objetivo desta pesquisa consiste em descrever e avaliar a atividade "Saúde Mental da Criança", que compõe o estágio de Pediatria Comunitária, desenvolvido no Centro de Saúde-Escola do Butantã, durante o primeiro ano de Residência em Pediatria.

Para alcançar este objetivo é fundamental a sua participação, enquanto residente, pois pretendo utilizar a avaliação que é realizada, por escrito, no final da atividade para fins de análise.

Portanto, solicito sua autorização para utilizar os dados, garantindo que não haverá qualquer tipo de identificação. As informações e procedimentos relacionados à pesquisa estarão disponíveis em qualquer momento. Sua participação é voluntária e não terá qualquer comprometimento relacionado ao Programa da Residência em Pediatria.

Os benefícios que poderão ser obtidos desta pesquisa certamente serão revertidos para o aperfeiçoamento do ensino na instituição na qual a pesquisa se insere. Seus resultados deverão ser publicados, contribuindo de forma significativa para a produção de conhecimento científico.

Agradeço, desde já, sua valiosa colaboração.

São Paulo, de de 2004. 
1 - Tinha uma idéia diferente do curso, antes do seu início. Acreditava que a abordagem dos temas seria pautada pelos casos recebidos no CS-E. Confesso que tive uma surpresa bastante agradável com a proposta apresentada(1). É uma excelente oportunidade para sairmos do "academicismo" a que já estamos acostumados e discutirmos temas que, infelizmente, não teremos muita chance de fazê-lo ao longo da residência. Ou melhor, talvez os temas possam ressurgir, mas não serão vastamente explorados, nem usarão literatura adequada para nortear as discussões (2). Quanto aos textos, acredito que todos tenham ilustrado bem as propostas correspondentes (3). Gostaria de fazer uma sugestão: ao invés de uma pessoa ficar responsável por um tema, acredito que duas pessoas poderiam ser incumbidas. Ás vezes, tiinha a impressão de que, durante a apresentação do tema, as pessoas ficavam meio perdidas, meio aéreas (quando os textos eram longos ou mais complexos). Talvez deixando dois responsáveis, a apresentação flua melhor(4).
\end{abstract}

$1^{\text {a }}$ idéia: O curso apresenta uma proposta inusitada e não convencional.

$2^{\mathrm{a}}$ idéia: O curso apresenta uma proposta sobre temas de extrema relevância que não são aprofundados durante a graduação e a residência.

$3^{\mathrm{a}}$ idéia: Os textos utilizados ilustram bem os temas propostos.

$4^{\text {a }}$ idéia: Sugestão: Duas pessoas deveriam ficar responsáveis pela apresentação e não uma.

2 - No início, foi difícil a leitura dos textos, $1^{\text {a }}$ idéia: A leitura dos textos foi difícil, no início, porém com a evolução dos temas pude me mas com a evolução do curso é possível familiarizar melhor com estas leituras e acompanhar melhor.

aproveitar melhor as discussões(1). A princípio, $2^{\text {a }}$ idéia: Foi de fundamental importância a achei que discutiríamos temas diretamente discussão de temas não-pediátricos.

ligados à Pediatria, porém foi de fundamental $3^{\text {a }}$ idéia: Tenho interesse em estudar mais importância e interesse a discussão sobre autores e temas e gostaria que houvesse outros temas "não tão pediátricos"(2). Eu, discussões periódicas

particularmente, tenho interesse em estudar mais sobre Freud, Piaget ... Pessoalmente, foi muito bom este contato com a Psicologia/Psicanálise, e gostaria de participar periodicamente em tais tipos de discussões(3).

3 - Em minha opinião, o curso de Saúde Mental, como parte do estágio em Pediatria Comunitária, foi excelente. Gostei muito dos textos propostos, mas principalmente das discussões (1). No início do curso, especialmente na primeira semana, quando trabalhamos com "O nascimento da Medicina Social", tive bastante dificuldade para ler o texto e, portanto, para me manter concentrada o suficiente para entendê-lo. Percebi isso ainda mais quando a $C$. apresentou-o, pois notei que durante sua leitura ela conseguiu retirar muito mais informações e entender melhor o que era dito com estas. No entanto, este tipo de texto era uma total novidade para mim e após a discussão percebi que tinha absorvido bastante informações novas. Com os textos das $1^{\mathrm{a}}$ idéia: O curso foi excelente.

$2^{a}$ idéia: A leitura dos textos foi difícil, no início, mas com a evolução do curso, é possível acompanhar melhor.

$3^{a}$ idéia: As férias durante o curso prejudica bastante o aprendizado dos conceitos, pois há uma lógica na seqüência dos temas.

$4^{a}$ idéia: Sugestão: discussão sobre os distúrbios alimentares. 


\begin{tabular}{|c|c|}
\hline 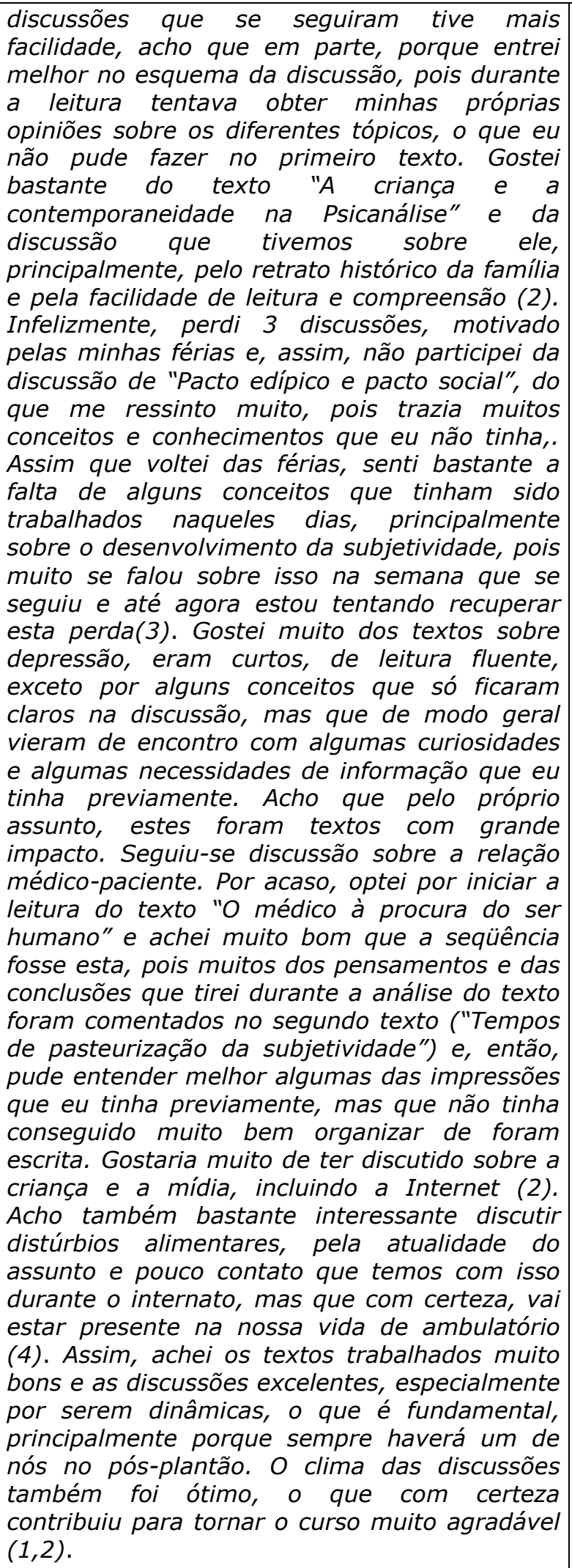 & \\
\hline $\begin{array}{l}4 \text { - As aulas de sexta-feira foram muito } \\
\text { produtivas, em relação ao estágio da Pediatria } \\
\text { Comunitária. A sexta-feira foi um dos módulos } \\
\text { mais proveitosos (1). No início do estágio eu } \\
\text { achei um pouco difícil acompanhar o raciocínio }\end{array}$ & 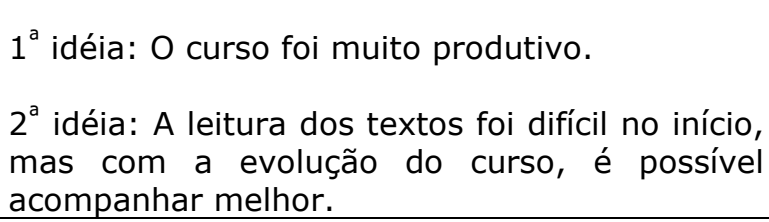 \\
\hline
\end{tabular}


seguido, principalmente por nunca ter entrado em contato com o assunto. Outro motivo da minha dificuldade inicial é o fato de eu aceitar apenas as informações concretas, quero dizer que é preciso que me prove uma informação para que eu a aceite. Durante o desenrolar do estágio eu fui me adaptando com os tipos de textos e tudo começou a fluir melhor (2). Eu não quis dizer que eu não aceitei muito menos que não aprendi nada, no decorrer do estágio, muito pelo contrário, meu conhecimento evoluiu muito, a cada sexta-feira que passava, eu adorava ir ao CS-E para as discussões. Achei muito bom tudo no estágio, "aprendi" a ler textos que não tem aquele formato que estamos acostumados, recebi muitas e muitas informações novas que são muito úteis no diaa-dia da nossa vida futura (como sobre a formação do sujeito, um tema que após o estágio considero essencial na formação de um pediatra!) (3). Espero que eu não tenha deixado uma imagem ruim durante o decorrer do curso, fiquei bastante quieto na maioria das sextas-feiras, mas não era porque eu não estava gostando das discussões, mas devido ao fato de eu gostar muito de ouvir discussões sobre esses temas, mas sempre julguei não existir certo nem errado quando se trata do inconsciente (não achei palavra melhor) do ser humano, então gosto muito de ouvir as opiniões e informações dos outros para armazená-las na cabeça e aos poucos ir formando e moldando a minha própria opinião. Concluindo a minha divagação, gostaria de dizer que os textos e as discussões foram muito produtivas e importantes para a nossa formação, realmente sinto que com esse conhecimento que nunca tinha chegado aos nossos ouvidos até hoje, temos a oportunidade de nos tornar médicos muito melhores $(1,3)$. $3^{a}$ idéia: Meu conhecimento evoluiu muito a partir do curso: recebi informações novas e úteis e aprendi a pensar sobre assuntos que não estava acostumado.

5 - Considero de grande importância os $1^{\text {a }}$ idéia: O curso apresenta uma proposta sobre seminários sobre o desenvolvimento da temas de extrema relevância que não são personalidade da criança, pois são levantados aprofundados durante a graduação e a aspectos que, normalmente, não são bem residência.

abordados, apesar da extrema relevância(1). O $2^{\text {a }}$ idéia: Os textos utilizados são pertinentes estudo do nascimento da Medicina Social e do aos temas e suscitam questionamentos, hospital traz a necessidade de se compreender reflexões e críticas.

a evolução histórica para a compreensão do $3^{\text {a }}$ idéia: Os textos são enriquecidos e papel atual da Medicina. A revisão histórica do esclarecidos pelas discussões em grupo.

conceito da criança aborda as mudanças de $4^{\text {a }}$ idéia: A coordenadora facilita a reflexão, atenção à infância de maneira completa, porém conduzindo as discussões com inteligência e com conclusões pouco compreensíveis objetividade.

enquanto que a "criança e a família na 5 a idéia: O estudo histórico da Medicina Social atualidade" ressalta o papel do masculino e do e do conceito de criança permitem feminino na família e a formação da compreender as mudanças de atenção à saúde personalidade de maneira crítica e objetiva (5) na infância.

- O "pacto edípico e pacto social" traz uma $6^{a}$ idéia: Ao panorama da cultura atual foi interpretação extremamente coerente e muito relacionado uma interpretação psicanalítica de importante é a conclusão feita sobre o problemas como depressão, delinqüência e surgimento da delinqüência e sua relação com fracasso escolar

a personalidade anti-social e com o complexo 


\begin{abstract}
de Édipo mal resolvido. "Mal-estar na atualidade" também associa objetivamente as questões da cultura atual à reflexão sobre a crise da Psicanálise, assim como a abordagem da depressão, chamando a atenção para a importância epidemiológica e social deste problema e de não banalizá-lo, tendo faltado apenas a definição clínica de depressão e seus critérios, como já havia sido lembrado em sala. Finalmente, a interpretação psicanalítica do fracasso escolar tornou esse problema mais compreensível e mais passível de resolução (6). Os textos parecem ter sido escolhidos de uma forma especial e, em sua grande maioria, tiveram propriedade nos assuntos abordados, nos suscitando qu estionamentos, reflexões e críticas(2). Todos eles foram enriquecidos e suas dúvidas elucidadas pelas excelentes discussões em sala(3). A facilitadora do curso teve um papel fundamental, ajudando-nos a refletir sobre os temas, trazendo exemplos, pensamentos e conclusões de maneira muito inteligente e objetiva(4). O estágio em questão teve a sua maior importância ao nos incentivar, através de textos e discussões a pensar na criança como sujeito, como integrante de uma família e de uma sociedade e que merece atenção especial na sua formação psíquica para a promoção de um desenvolvimento saudável(5).
\end{abstract}

6 - Acredito que na primeira sexta-feira do estágio se iniciou um processo que não cessará com o final do estágio, afinal muitas questões foram despertadas, pontos de vista foram mudados, passamos a enxergar, por exemplo, que junto com um bebê que cresce, se desenvolve também um sujeito (1). Fomos o primeiro grupo a experimentar uma nova proposta no âmbito da Saúde Mental, que foi a de tomar contato com questões que afligem a população e não somente o indivíduo. No início, resistimos, achamos os textos difíceis, mas à medida que o tempo foi passando $e$ as discussões avançando, fomos ficando mais a vontade e com maior intimidade com os assuntos (2). Foi muito bom entender o nascimento da Medicina Social e do hospital e fazer relações com suas organizações atuais, entender como evoluiu a maneira de ver a criança, discutir as raízes da violência a que assistimos inconformados em nossa sociedade, além desse mal-estar disseminado entre nós, que gera depressões, fracasso escolar, quebras na relação médico-paciente, entre outras coisas (3). Melhor ainda é olhar para trás e perceber o encadeamento de idéias entre todos os assuntos discutidos (4). Foi essencial termos um tempo dedicado a parar, refletir sobre estas questões e poder compartilhar opiniões e experiências com um grupo (5). Aprendemos muito, certamente este foi um momento $1^{a}$ idéia: O curso proporcionou uma abertura para mudanças e questionamentos.

2 idéia: A leitura dos textos foi difícil no início, mas com a evolução do curso, é possível acompanhar melhor.

$3^{a}$ idéia: Através de um percurso histórico foi possível compreender a Medicina, a visão da criança, as raízes da violência e o mal-estar disseminado, que gera depressões, fracasso escolar etc.

$4^{a}$ idéia: Existe um encadeamento de idéias entre todos os assuntos discutidos.

$5^{\text {a }}$ idéia: Foi essencial refletir e compartilhar opiniões e experiências com o grupo.

6 idéia: O curso foi marcante para a formação porque aprendi muito.

$7^{a}$ idéia: Pude desabafar, fui acolhida e compreendida. 


\begin{abstract}
bastante marcante de nossa formação e continuaremos colhendo os frutos, ao longo de nossa vida profissional e pessoal (6). P.S.: Além disso tudo, gostaria de agradecer e dizer que ao chegar para as aulas de sexta-feira de manhã, muitas vezes, cansada após uma noite de plantão me sentia acolhida. Muitas vezes, pudemos desabafar e fomos compreendidos (coisa rara, desde o ingresso na faculdade) (7). Obrigada! Foi muito legal!
\end{abstract}

7 - No primeiro contato, foi colocada para o $1^{\text {a }}$ idéia: O curso propõe discussão de temas grupo uma proposta de trabalho para o estágio em Saúde Pública, especificamente em "Saúde Mental": discussão de temas de Pediatria, sob uma óptica relacionada às interesse em Saúde Pública, e mais Ciências Humanas.

especificamente em Pediatria, sob uma óptica $2^{a}$ idéia: A leitura dos textos foi difícil, no início, mais relacionada às Ciências Humanas e mas com a evolução do curso é possível Psicossociais(1).No início, confesso que houve acompanhar melhor.

um certo desconforto de minha parte, $3^{\mathrm{a}}$ idéia: 0 direcionamento histórico permite principalmente após a leitura dos primeiros relacionar várias conseqüências no mundo em textos. Não estava habituada a fazer este tipo que vivemos, as estruturas da sociedade e a de leitura e tive dificuldades para compreender evolução do modo de pensar.

os primeiros textos. Após a discussão, o $4^{\text {a }}$ idéia: Através de um percurso histórico é desconforto melhorou substancialmente, pois possível localizar as propostas da Pediatria novos conceitos foram se estabelecendo ou Comunitária, a situação da criança na clareando e as discussões se tornavam atualidade, a formação da subjetividade e a ilustrativas e agradáveis. A cada texto a leitura discussão de temas relacionados a estes se tornava mais fácil de ser compreendida, pontos.

embora continuasse uma linguagem difícil, não $5^{a}$ idéia: Seria interessante discutir os habitual(2). Achei bastante interessante distúrbios de comportamento em crianças, pois também o direcionamento histórico colocado não sabemos como abordar.

em alguns textos, pois me fez pensar e $6^{\text {a }}$ idéia: Foram atividades produtivas que já relacionar várias conseqüências no mundo em tem um reflexo na prática.

que vivemos, as estruturas da sociedade e do modo de pensar de gerações anteriores(3). A ordem que foi estabelecida para as discussões é interessante, pois parte de um "todo maior" que seria o surgimento da Medicina Social, importante no âmbito das propostas da Pediatria Comunitária, seguindo com uma noção do conceito e percepção da criança na sociedade através dos tempos, o surgimento da Pediatria como ramo da Medicina e a situação da criança na atualidade, passando pela formação da subjetividade humana e desenvolvimento deste sujeito, caracterizando a inserção deste sujeito, que é único, num ambiente social e por fim discutindo temas da atualidade e relacionados à criança como depressão, fracasso escolar e a relação médicopaciente(4). Não sei como isso seria possível, mas acho que seria interessante também um espaço para discussão sobre a criança e a mídia, que não foi realizada em função do tempo e sobre distúrbios de comportamento em crianças, que muitas vezes entramos em contato e não sabemos como abordar(5). Foram atividades produtivas, que já estão tendo um reflexo na prática diária (6).

8 - Achei que os temas foram bons, abrindo $1^{\text {a }}$ idéia: Os temas foram bons e abriram uma 
novos conhecimentos e nos fazendo pensar em novos aspectos da relação médica (1); porém achei o método de discussão muito cansativo. Acho que uma pessoa falando por mais ou menos quatro horas é muito pouco produtivo.. Também acho muito teórico e pouco prático (2). Sugiro que os textos sejam dados para serem lidos e discutidos, porém acho que também podem ser discutidos métodos práticos de consulta com crianças, casos clínicos de crianças com problemas psicológicos (por exemplo, depressão, fracasso escolar, dificuldade de alimentação) (3). No ensino médico, temos pouca oportunidade para aprendermos a lidar com o lado emocional da criança e acho esse espaço ideal. Temos muitas dúvidas para abordar clinicamente e acompanhar essas crianças. Sei que é pouco tempo, mas pode nos auxiliar nesse sentido. Acredito que a visão médica de atendimento vem mudando, no sentido de avaliarmos a criança como um todo e para isso é necessário que sejamos ensinados e treinados para isso. Para deixarmos de ser apenas médicos que visam a patologia e sim cuidarmos do paciente como um todo (4).

9 - Sexta-feira, 13. Muitas pessoas teriam 1 medo de sair de casa num dia como este. Da minha parte, acho esta data interessante, pois nasci numa sexta-feira, 13, no mês de janeiro há 25 anos atrás. Sei que parece um início sem sentido para o trabalho encomendado, mas não consegui não reparar nela e acho que durante este estágio, aprendi a reparar em alguns detalhes que possivelmente antes passariam batido. Estou falando de observações no meu dia-a-dia como médica, como amiga e como pessoa (1). Foi interessante discorrer sobre Édipo e sua influência no crescimento das crianças, da sua importância como modelador de pessoas capazes de tomar decisões, de se desligar da barra da saia da mãe, de encarar o mundo e o cotidiano de um jeito diferente, apreciando as dificuldades como cortes consecutivos do cordão umbilical, ao que fomos expostos inconscientemente em algum momento nas nossas vidas ou pelo menos deveríamos ter sido. É inevitável pensar na influência que nossos pais tem acima de nós, estando presentes ou ausentes, eles marcam nossas vidas, não é à toa que muitas vezes escutamos frases como: "você tem de ser o que eu não consegui ser" ou "não cometas o mesmo erro que eu"; eles vão se entregando para conseguir dar a seus filhos aquilo que eles acham importante, dando ao mesmo tempo exemplos de esforço e dedicação... mas será que o esforço de fazer filhos fortes, preparados para a vida, filhos resilientes, deixa a criança, logo adolescente e depois adulto, preparado para a vida? Na teoria sim, mas se fosse tão perspectiva nova para pensar o trabalho médico.

$2^{a}$ idéia: 0 método de discussão é muito cansativo e pouco produtivo.

$3^{a}$ idéia: Acho que devem ser discutidos métodos práticos de consultas com crianças com problemas psicológicos.

$4^{a}$ idéia: Não sabemos como lidar com o lado emocional da criança e este seria o espaço ideal para aprendermos isso.

$1^{\text {a }}$ idéia: Aprendi neste estágio a observar melhor os detalhes que compõem a meu dia-adia como médica e pessoa.

$2^{a}$ idéia: Foi importante compreender teoricamente, através do Complexo de Édipo, a influência dos pais sobre a formação da identidade dos filhos e as diversas modalidades patológicas. 
simples, a vida perderia um pouco a graça, não teríamos lugar para sentirmos tristeza, medo, o gosto da derrota e da vitória (2). Ao longo dos anos, as pessoas vão acumulando experiências que as torna indivíduos únicos, na maioria das vezes diferentes daquela imagem no espelho pela qual os pais sempre lutaram, o que muitas vezes os deixa triste... mas por que ficar triste? Os filhos não são dos pais, os filhos são da vida, caso contrário nasceríamos como apêndices colados a eles... os pais também foram filhos, só que eles esquecem esta condição anterior. Na vida, no dia-a-dia, hoje é difícil não se enfrentar situações que testam nossa força e nossa personalidade, que desde a infância é construída com ajudo do entorno e principalmente pelo ambiente na família, é difícil não se enfrentar as situações que nos deixam mais tristes, talvez deprimidos, mas por que alguns indivíduos tem dificuldade maior de sair e dar a cara para bater e enfrentar esses problemas, por que é mais difícil para algumas pessoas se sobrepor a estas situações? Muitos falam da depressão, alguns como doença outros como síndrome, outros como meros leigos que sofrem com ela... outros podemos falar como pessoas que lutamos contra ela e não nos deixamos abater por ela, quero dizer, não chegamos a "ficar" deprimidos, mas sentimos uma sensação de que ia acontecer. Desde este ponto de vista, acho que o jeito em que fomos criados, ou seja, nosso meio ambiente desde crianças, os exemplos que observamos, o apoio de nossos pais dando força nos momentos difýceis em que uma criança pode ficar deprimida (porque acredito que as crianças também ficam deprimidas), ficar do lado quando perdemos, sorrir quando ganhamos e mesmo após a derrota, enfrentando os problemas e nos ajudando a resolver o que não conseguimos resolver dando espaço ao mesmo tempo de respirar fundo e falar: eu posso, eu consigo sair desta, é só uma pedra no caminho, vamos tentar encontrar o atalho ou então, vamos juntar forças para pular por cima. Tudo isto faz parte importante da vida das pessoas e nem todas conseguimos isto tão rapidamente, alguns temos de apanhar um pouco para aprender a parar, não desesperar e respirar fundo. A família é a maior rede de laços que o ser humano pode ter, para se sustentar nesta vida de ventos cruzados, aos poucos, as pessoas percebem que a única rede segura é a família...(2) mas que acontece com aqueles que perderam a rede? Ou então, a rede vai se rompendo aos poucos? Alguns conseguem seguir pelo fio que sobra, tricotando uma rede a partir dele, outros não conseguem se segurar e caem...mas por que acontece isto? Às vezes, acho que sei a reposta e às vezes acho que não tenho a mínima idéia. Quando acho que sei, penso que se pelo menos temos um exemplo 
de fortaleza, de garra frente a adversidade, aprendemos a ver nos outros exemplos de força, pois se pararmos para penar com certeza, encontraremos alguém com um problema pior que o nosso, que parece um mar e quando realmente abrimos os olhos não é mais do que um copo de água! Aprendemos que chega um momento da vida em que é nossa vez de iniciar uma rede, pois não somos só parte de um todo e sim, o início de outra rede. Aprendemos a ver que somos pessoas independentes com capacidade de ir para frente, aprendemos que nascemos sozinhos e que não podemos ser dependentes eternamente da nossa rede inicial, se conseguimos perceber isto, a vida fica ligeiramente mais fácil. Acho que parar para refletir sobre o Édipo no contexto da formação da personalidade do sujeito, do seu vínculo com os pais e com o meio que está ao seu redor, da sua influência na individualidade da criança foi importante, pois ajuda a entender comportamentos de pais e filhos nos seus relacionamentos, nas suas dependências e independências. Parar para pensar em depressão, foi um momento de retroalimentação para reconhecer quão importantes são os pais, seus exemplos, Quanto é difícil manter a rede e como é importante aprender a tricotar a nossa rede, como pessoas independentes, que no futuro poderá sustentar outras pequenas redes(2). Se me perguntarem quem eu quero ser ao crescer, responderia: quero ser como meus pais, tentando uma versão melhorada dos dois, eles são grandes. Obrigada pelo espaço para falar.

10 - Acho interessante que a residência de Pediatria nos ofereça a oportunidade de pensar o paciente também como sujeito de emoções e essência psíquica, compreendendo que o equilíbrio entre saúde e doença tem aspectos que não são puramente orgânicos (1). O curso se destaca por tentar mostrar a realidade em que estão inseridas as crianças, sua família, o conceito e formação histórica do núcleo familiar. Tudo isso mostra um detalhamento e uma riqueza que, se bem explorado na prática clínica, pode dar pistas importantes para o melhor acompanhamento do paciente (2). Também foi interessante a abordagem de temas "psi", como o Édipo, a formação do sujeito, a influência materna e a paterna nesse processo, pois embora esses conhecimentos sejam até que populares, espera-se que um pediatra possa oferecer mais do que uma visão leiga do assunto e o curso é bem-sucedido em nos dar embasamento para tal(3)Em suma, um curso interessante e bem colocado no R1, época em que estamos compreendendo a criança da forma mais generalista (4).

$1^{\text {a }}$ idéia: O curso contribui para ampliar a visão da Pediatria, identificar e atuar sobre os aspectos psíquicos do paciente, para além do orgânico.

$2^{a}$ idéia: O curso fornece elementos para aplicar na prática clínica.

$3^{a}$ idéia: O curso é bem-sucedido pois nos dá embasamento teórico para compreender as influência dos pais na formação da subjetividade da criança.

$4^{a}$ idéia: O curso é interessante e está bem colocado no Programa de Residência.

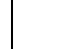




\begin{tabular}{|c|c|}
\hline $\begin{array}{l}12 \text { - Durante as últimas semanas, tivemos } \\
\text { oportunidade de discutir uma série de } \\
\text { informações, das quais boa parte eram novas } \\
\text { para mim (1). Pude esclarecer várias questões, } \\
\text { principalmente relacionadas à Psicanálise, as } \\
\text { quais antes me pareciam estranhas e até } \\
\text { mesmo absurdas. Isso devido à falta de } \\
\text { conceitos e definições, que antes acabavam } \\
\text { sendo interpretadas de maneira errônea (2). } \\
\text { Os temas abordados foram interessantes e } \\
\text { atuais, e pudemos aproveitá-los em outros } \\
\text { momentos (como por exemplo, em algumas } \\
\text { aulas do Ambulatório do HU e mesmo no Posto } \\
\text { de Saúde, durante as discussões sobre } \\
\text { desenvolvimento, nos estágios da creche e nas } \\
\text { discussões realizadas às quintas-feiras) (3). } \\
\text { Acho que a metodologia empregada foi } \\
\text { interessante, pois muitas das minhas dúvidas } \\
\text { que surgiam durante a leitura, foram } \\
\text { esclarecidas no momento da discussão. Mas } \\
\text { reconheço que quando determinado tema } \\
\text { ficava sob minha responsabilidade, a leitura do } \\
\text { texto era feita de forma mais detalhada } \\
\text { (refazendo a leitura outras vezes, com maior } \\
\text { esforço para tentar compreender as partes } \\
\text { miais difíceis). E quando o tema era } \\
\text { apresentado por outra pessoa, a leitura era } \\
\text { feita de forma mais "light", sem me prender } \\
\text { muito a detalhes. De modo geral, o } \\
\text { aproveitamento foi muito bom (interessante o } \\
\text { fato de que acabávamos resgatando várias } \\
\text { vezes assuntos discutidos previamente, } \\
\text { reforçando o que já havia sido visto) (4). Foi } \\
\text { uma grande oportunidade para refletirmos um } \\
\text { pouco sobre as mudanças atuais de } \\
\text { comportamento, estrutura familiar e toda a }\end{array}$ & 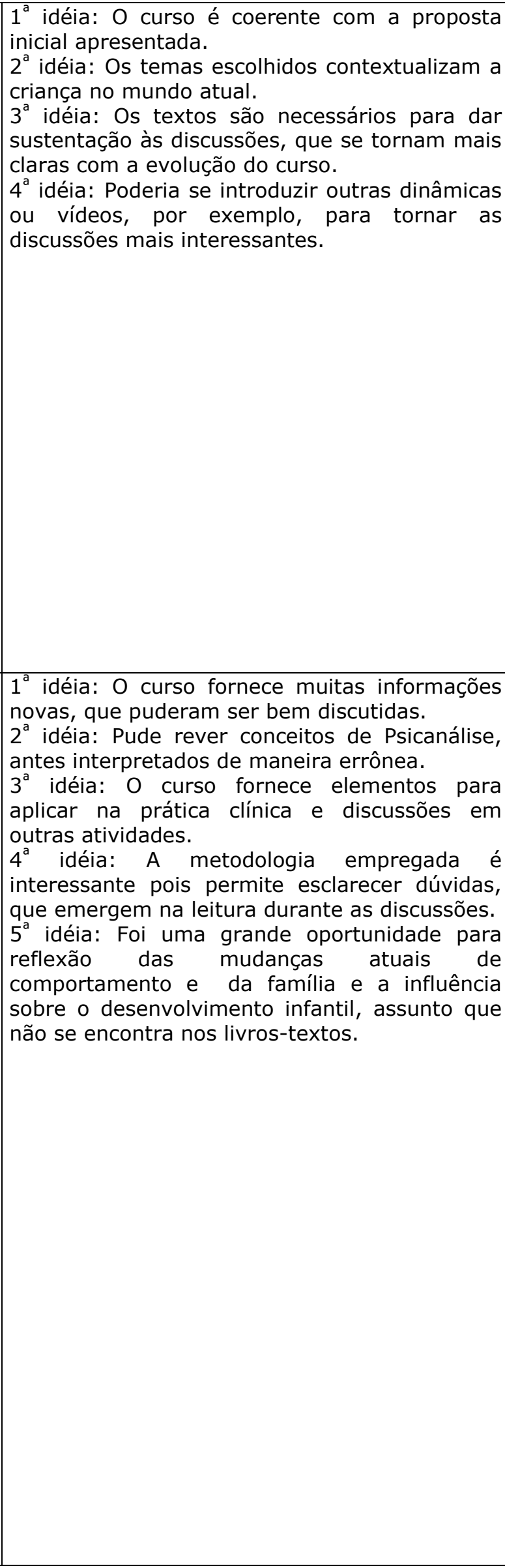 \\
\hline
\end{tabular}




\begin{tabular}{|l|ll|}
\hline influência dessas mudanças & sobre & o \\
desenvolvimento infantil, o & que & não \\
encontramos em livros-textos (5). & &
\end{tabular}

13 - Foi muito interessante debater temas de $1^{\text {a }}$ idéia: Pude rever conceitos de Psicanálise, Psicologia ligados muitas vezes à Medicina. antes interpretados de maneira errônea

Clareou bastante para mim, assuntos da $2^{a}$ idéia: 0 curso fornece elementos para Psicanálise que eu era, muitas vezes, contra. aplicar na prática clínica.

Eu realmente não entendia Freud e agora vejo $3^{\mathrm{a}}$ idéia: A leitura de alguns textos foi difícil, que há sentido em algumas coisas que ele mas com a evolução do curso, é possível afirmava (1). Em certos caso que vejo no acompanhar melhor.

ambulatório, deu para entender melhor a $4^{\mathrm{a}}$ idéia: Poderia mudar a dinâmica de dinâmica familiar e até conhecer melhor o apresentação, que é cansativa, com questões "sujeito"(2). Alguns textos foram muito prévias para orientar a reflexão e a discussão interessante e "gostosos"' de ler, mas outros em grupo

eu achei muito difícil, pois não estamos acostumados a ler textos aprofundados em Psicanálise (3). Poderia ser mudado um pouco a dinâmica da apresentação dos temas, pois na prática só fica a pessoa que vai apresentar falando sozinha e os outros escutando (eu, particularmente sempre de pós-plantão, ficava com sono) (4). Foi muito pertinente as suas intervenções e palpites que ajudavam a esclarecer os textos(3), mas a pessoa que apresenta praticamente lê o texto. Talvez se tivesse questões orientadoras ou tópicos para maior reflexão e opinião do grupo, seria mais interessante.(4)

14 - Achei os temas abordados pertinentes, as discussões muito boas, ricas e produtivas, sustentadas por textos diferentes do habitual de leitura médica, uma abordagem diferente e muito válida, trouxe-me elementos úteis para minha prática médica (e não só médica, para a vida!)(1). Também me trouxe a possibilidade de conhecer melhor meus colegas, possibilitando um melhor vínculo entre nós: um presente de relacionamentos! Uma prática da relação entre as pessoas!!! Um ponto muito importante que achei fundamental foi o foco nos temas, não houve digressões que fugissem do tema ou não fossem úteis!(2)

15 - Gostei muito (1), nos permitiu aprender $1^{\text {a }}$ idéia: Gostei muito.

mais sobre temas comumente enfrentados em $2^{\text {a }}$ idéia: 0 curso fornece elementos para nosso ambulatório didático e com um enfoque aplicar na prática clínica.

distinto da Psiquiatria (2). Iria sugerir mais temas (como enurese), porém vi que se encontram no roteiro inicial, não sendo vistos com nosso grupo por falta de tempo. Peço desculpas pela tagarelagem, os atrasos e o sono nos pós-plantões. Foi importante aquele diálogo inicial onde algumas revelações foram feitas. O nosso grupo não é o mais unido... Sugiro que monte uma apostila com os temas propostos como a da creche para que facilite a obtenção do xerox para suas discussões. Apesar do pouco contato, você me pareceu uma ótima pessoa.

16 - O curso teve um conteúdo muito bom e é extremamente importante por trazer para discussão temas como o desenvolvimento na óptica da Psicanálise e da Psicologia. A discussão da importância da relação mãefilho, estruturação do sujeito e como seus desvios se $1^{\text {a }}$ idéia: O curso fornece elementos para aplicar na prática clínica.

$2^{a}$ idéia: As atividades oferecem a possibilidade de conhecer melhor os colegas, enriquecendo os výnculos do grupo. $1^{\text {a }}$ idéia: Foi importante compreender teoricamente através do Complexo de Édipo, a influência dos pais sobre a formação da identidade dos filhos e as diversas modalidades 
mostram como sintomas, muitas vezes, referidos nas consultas, foi muito boa (1). Os textos ajudam a orientar as discussões, embora, às vezes, possuam uma linguagem a que não estamos acostumados, sendo um pouco difíceis de compreender. Acho que mais importante do que os textos são as discussões(2). É pena que o curso seja tão curto, restrito apenas ao estágio de Pediatria Comunitária, já que o tema é muito amplo e merecia ser extrapolado para os outros estágios, pois acho fundamental a discussão da esfera psíquica do desenvolvimento da criança, bem como das relações familiares e da criança com o meio(3). Aprendi muito no curso e creio estar agora com olhos e ouvidos mais atentos para os aspectos da relação mãe-filho e do desenvolvimento emocional da criança.(4)

17 - Gostei muito das nossas discussões, dos textos indicados para leitura e dos temas que foram bem relevantes(1). O curso cumpre com a proposta.(2) Acredito que deve-se continuar o enfoque em problemas relevantes da prática clínica, mas sem necessariamente abordar as patologias e sim,através de temas centrais sobre o sujeito e a constituição de sua psique. Desta forma, temos base para entender e estudar as doenças que advém da variação do que é considerado a constituição da normalidade. Estes temas centrais não são priorizados em nenhum outro momento do programa de residência, nem mesmo o foi na graduação, reforçando a importância das nossas discussões. Foram também abordados assuntos que são queixas das mães que deparamos no consultório: "meu filho não come”, "meu filho não vai bem na escola", temas que não somos preparados para abordar (1). Nossas discussões ampliaram a visão dos fatores que estão envolvidos nestas queixas. Elas também deram suporte para buscarmos respostas e compreensão das dificuldades que envolvem a relação pais e filhos $e$ até mesmo para nos prepararmos como futuros pais $e$ mães.(3)

18 - O curso de Saúde Mental nos revela uma abordagem mais humana e social da visão do mundo, da relação entre as pessoas, do próprio sujeito e suas alterações, sintomas $e$ da própria Medicina.(1) Pode me abranger o ponto de vista, de como entender melhor o outro. É um curso dado de forma muito dinâmica, interagindo todos durante a aula, onde diferentes opiniões podem ser expressas $e$ entendidas(2). Os temas abordados foram bons, sendo todos muito explorados ("esgotados"). Gostei muito desse curso, foi muito aproveitado; pena que é curto. Poderia ser abrangido (caso houvesse mais tempo) mais temas. Com certeza, me enriqueceu muito.(3)

19 - Foi bem proveitoso, mas sugiro, se possível, maior discussão de casos clínicos relacionados a alguns tópicos, para sedimentar ainda mais o rico conteúdo das discussões. Sugiro que fracasso escolar, depressão e psicoses na infância, por exemplo, sejam ilustrados com discussão de caso. Obrigada pelas orientações e pelo conhecimento que nos foi passado (1).

$20-E$ Eratificante poder ter um momento nessa vida corrida que é a Medicina (Pediatria, em especial) para sentar e conversar sobre assuntos muito pertinentes em nossa vivência diária. Mais do que entender melhor as patológicas

$2^{\text {a }}$ idéia: Os textos ajudam a orientar e dar sustentação às discussões que se tornam mais claras com a evolução do curso.

$3^{a}$ idéia: Gostaria que houvesse discussões periódicas e tenho interesse em estudar mais autores e temas.

$4^{a}$ idéia: O curso foi marcante porque aprendi muito.

$1^{\text {a }}$ idéia: O curso apresenta uma proposta sobre temas relevantes que não costumam ser abordados.

$2^{a}$ idéia: O curso é coerente com a proposta apresentada.

$3^{a}$ idéia: 0 curso fornece elementos para aplicar na prática clínica e discussões em outras atividades. $1^{\text {a }}$ idéia: 0 curso propõe uma abordagem humana e social do sujeito nas suas relações, seus sintomas e da própria Medicina.

$2^{\text {a }}$ idéia: A dinâmica do curso permite refletir e compartilhar opiniões e experiências com o grupo.

$3^{a}$ idéia: 0 curso oferece muitas informações novas que puderam ser bem discutidas. $1^{\text {a }}$ idéia: Seria interessante discutir mais casos de distúrbios de comportamentos em crianças, pois não sabemos como abordar.

$1^{a}$ idéia: 0 curso permite conhecer melhor a nós mesmos. 
relações entre os nossos pacientes, seus pais e o meio que os cercam, o curso nos permitiu conhecer melhor a nós mesmos: cada um em separado e grupo como um todo. Os benefícios serão levados para o resto da residência e, mais importante, para nossas vidas. Obrigada!(1)

21 - O curso, em geral é bastante bom. As primeiras semanas são mais áridas, entretanto, acredito que isso seja até certo ponto necessário, pois é preciso discutir e formar as ferramentas que serão usadas em discussões posteriores.

As discussões ocorrem de forma bastante aberta. Quando há alguma dúvida ou divergência de opinião, é sempre exposta com grande liberdade. No geral, considero que todos saímos bastante enriquecidos, tanto em nosso conceitos quanto em nossa compreensão dos pacientes e da nossa relação com eles. Agradeço à Raquel a possibilidade $(1,2)$.

22 - A expectativa desses encontros já era grande, pois a Saúde Mental da criança sempre foi um assunto, dentro da Medicina, do meu interesse. Compreender a si próprio não é tarefa fácil, deve-se percorrer um árduo trajeto através da própria existência, trilhar a mais íntima história, e só assim nascer de novo. Cada dia, um nascimento, a cada passo uma nova compreensão... e no fundo, sabemos tão pouco! O desejo de encontrar as respostas, o medo de não achá-las, os desafios, as cobranças, a derrota... o vencer!! No fundo, nossos caminhos de adultos são tão "infantis", no sentido de que nossa existência é tão efêmera e tão incerta: uma eterna criança, que adormece, mas não morre, durante toda a vida, ao nosso lado. Foi importante o curso de Saúde Mental para refletir sobre essa aproximação que cada um de nós, que escolhe a criança como objeto de trabalho, tem com o mundo infantil, lúdico, e como isso é sentido por nós quando atendemos uma criança.(1) Por outro lado, o contato tão constante com as mães... nossas mães? Nós, como mães? Tudo se mistura, não é mesmo? Foi bom abordar queixas tão freqüentes no dia-a-dia dos ambulatórios, pronto-socorro, numa visão um pouco mais profunda, menos imediatista e menos "causa-efeito".(2) Os textos acrescentaram muito na formação geral, enquanto ser humano, enquanto pediatra $e$, principalmente, no olhar a criança.(3) A "escuta" é valorizada e é bom poder ouvi-las. É importante saber reconhecer as outras formas de linguagem da criança. Tudo é linguagem: o choro, a raiva, o medo, a recusa... a criança pequena não fala o idioma, mas domina outra forma de comunicação, a qual não estamos habituados, talvez, nem as mães... Ficou uma boa bagagem desse curso; com certeza me acrescentou muito e me ajudou a tentar diferenciar a criança saudável, com algum distúrbio de comportamento, daquela que não fez vínculo, que não pode ser acompanhada $1^{a}$ idéia: A leitura dos textos foi difícil, no início, mas com a evolução do curso, é possível compreender melhor.

$2^{a}$ idéia: Meu conhecimento evoluiu muito a partir do curso: recebi informações novas e aprendi a pensar sobre assuntos que não estava acostumado.

$1^{\text {a }}$ idéia: O curso foi importante para refletir sobre a escolha da criança como objeto de trabalho.

$2^{a}$ idéia: 0 curso fornece elementos para aplicar na prática clínica.

$3^{\mathrm{a}}$ idéia: Através de um percurso histórico é possível compreender a situação da criança na atualidade, a formação da subjetividade e as modalidades patológicas. 
apenas com o pediatra e por isto, precisa ser acompanhada pelo profissional de Saúde Mental. Isso só ficou claro, a partir do entendimento, através dos textos e das discussões, de que para compreender a criança deste século, deve-se saber o momento histórico atual e suas heranças. Nesse aspecto, o curso ajudou bastante.(4) Foi muito bom, Raquel!! Pena ter acabado!!

23 - Adorei o estágio!!(1) Eu, particularmente, $1^{\text {a }}$ idéia: Adorei o estágio.

interesso-me bastante por higiene mental. $2^{a}$ idéia: O curso contribui para ampliar a visão Acho importante que o médico seja capaz de da Pediatria, identificar e atuar sobre os enxergar mais que somente um corpo humano, aspectos psíquicos do paciente, para além do mas também o "ser" - com todas suas orgânico.

neuroses - que a ele dá vida. Além de nos $3^{\text {a }}$ idéia: A dinâmica do curso permite refletir e ampliar a visão em relação ao paciente, os compartilhar opiniões, sentimentos e temas abordados, nos permitiram avaliar um experiências com o grupo.

pouco as possíveis interações da criança com o meio, em diversos sentidos. Como a criança é vista atualmente pela sociedade? Que papel ela exerce? A que distúrbios psicológicos ela está submetida? Quais são as aspirações da juventude de hoje? Entre outras questões...(2) O mais interessante é que o estágio abriu um canal para que pudéssemos expor, além de nossas opiniões, os nossos sentimentos. Fomos tomados, durante as discussões, por momentos de raiva, indignação, conivência, entre outros sentimentos mais difíceis de serem nominados. Foi, sem dúvida, uma experiência interessante. Às vezes, saía da sexta-feira de manhã pensativa... outras, revoltada! Não importa qual o sentimento a vigorar em cada ocasião, uma certeza eu tinha: valeu a pena! (3) Muito obrigada!

24 - O período semanal reservado às discussões com a Raquel no estágio CS-E do Butantã é extremamente agradável. Creio que o curso é conduzido por uma profissional muito bem capacitada, não-autoritária e interessada a respeito de qualquer assunto trazido às discussões.(1) Tenho, no entanto, uma grande crítica... aos objetivos do curso. Percebo uma oportunidade única na residência médica de aprender algo sobre saúde mental e seu uso prático na Pediatria, que não é utilizada para isso. Os temas escolhidos nos fazem pensar, trazem novos elementos às nossas vidas, ou seja têm seus objetivos e seus pontos positivos. Porém, não ajudam, de forma prática, a identificar psicopatologias pediátricas ou como lidar na suspeita das mesmas. Creio, ainda, que o espaço democrático e aberto para discussão de casos não supre tal demanda (2). Fica registrada minha admiração aos pontos positivos ressaltados, assim como minhas sugestões.

25 - Gostei bastante do curso (1). Acho que as $1^{\text {a }}$ idéia: Gostei bastante do curso.

discussões foram super-produtivas, mudaram $2^{\text {a }}$ idéia: Meu conhecimento evolui muito a meu modo de pensar, "abrindo minha partir do curso: recebi informações novas e 
cabeça"(2). Gostei de aprender um pouco sobre a visão da Psicanálise. Foi um pouco, mas o suficiente para acabarem com alguns dos pré-conceitos que eu tinha (3). Os temas foram bem selecionados, com textos que prendem a atenção.(4) Muito bom!

26 - O curso de sexta-feira foi importante para minha formação como médica pois pôde me fazer compreender melhor a relação com meus pacientes. Através da leitura dos textos e das discussões em grupo, foi possível entender melhor meus sentimentos em relação ao paciente e como posso tentar melhorar o vínculo com alguns deles. Além disso, me fez entender porque alguns pacientes e a família têm determinados comportamentos.(1) É o único espaço dentro da residência que permite que expressemos nossas angústias em relação às consultas que temos e saber a opinião e os sentimentos de outras pessoas sobre seus pacientes.(2)

27 - Gostei muito deste estágio, foi uma oportunidade única na residência de ter contato com a higiene mental e com outros profissionais de saúde, não-médicos, que permitiram uma outra visão dos temas abordados. (1) Gostei também do espaço dado para a discussão das angústias, que nós, residentes, passamos no consultório e na relação com os pacientes.(2) Uma sugestão seria reservar um tempo para a discussão de alguns temas específicos de psicopatologias pediátricas.(3)

28 - As discussões das sextas-feiras foram $1^{\text {a }}$ idéia: O curso apresenta uma proposta sobre muito interessantes, já que pudemos refletir temas de extrema relevância que não são sobre assuntos relevantes e que, às vezes, aprofundados durante a graduação e a devido à correria do dia-a-dia eram vistos residência.

como secundários (1). Pudemos ler e $2^{\text {a }}$ idéia: A dinâmica do curso permite refletir e compartilhar opiniões distintas frente a cada compartilhar opiniões, sentimentos e assunto e desse modo, enriquecer nossa lógica. experiências com o grupo.

Em algumas situações, antes do início das $3^{\text {a }}$ idéia: O direcionamento histórico permite discussões, eu apresentava determinada relacionar várias conseqüências no mundo em opinião e, após ouvir o que cada um entendia que vivemos, as estruturas da sociedade e a por determinado tópico, me vi mudando meus evolução do modo de pensar.

conceitos.(2) A leitura de textos escritos por $4^{\mathrm{a}}$ idéia: O curso foi marcante para a formação filósofos, psicólogos, antropólogos e porque aprendi muito.

historiadores me fez entender a origem, as $5^{\text {a }}$ idéia: É um espaço para ouvir e ser ouvido. razões e os diversos pontos de vista sobre assuntos da atualidade.(3) Achei esse estágio importante para minha formação de médica, já que foi o único espaço da residência reservado para discussões de questões éticas e psicossociais. (4) É um espaço para ouvir e ser ouvido.(5)

29 - Achei muito proveitoso e atuais os temas abordados, a forma com que as discussões ocorreram permitem o debate de forma democrática e permitiu um maior contato com $1^{\text {a }}$ idéia: Foram atividades produtivas que já tem um reflexo na prática.

$2^{\mathrm{a}}$ idéia: O curso apresenta uma proposta sobre temas de extrema relevância que não são 


\begin{tabular}{|c|c|}
\hline $\begin{array}{l}\text { a Psicologia e higiene mental.(1) Mesmo com } \\
\text { nossa ignorância parcial frente à Psicanálise, as } \\
\text { discussões e debates permitiram um ótima } \\
\text { introdução sobre o tema, muito pouco } \\
\text { abordado na nossa residência.(2) Acabou } \\
\text { abrindo portas e permitindo que observasse } \\
\text { meus pacientes com novo ponto de vista, } \\
\text { permitindo que eles abordassem problemas, } \\
\text { muitas vezes, ignorados em consultas } \\
\text { anteriores (1). Quando necessário e possível, } \\
\text { as discussões sobre casos clínicos, também } \\
\text { foram positivas e esclarecedoras(3). Apesar de } \\
\text { sucinta, minha avaliação do estágio e de } \\
\text { nossas discussões é excelente, gostaria de tê- } \\
\text { la realizado no início do ano.(4) }\end{array}$ & $\begin{array}{l}\text { aprofundados durante a graduação e a } \\
\text { residência. } \\
3^{\mathrm{a}} \text { idéia: As discussões de casos clínicos foram } \\
\text { muito proveitosas. } \\
4^{\mathrm{a}} \text { idéia: O estágio foi excelente. }\end{array}$ \\
\hline 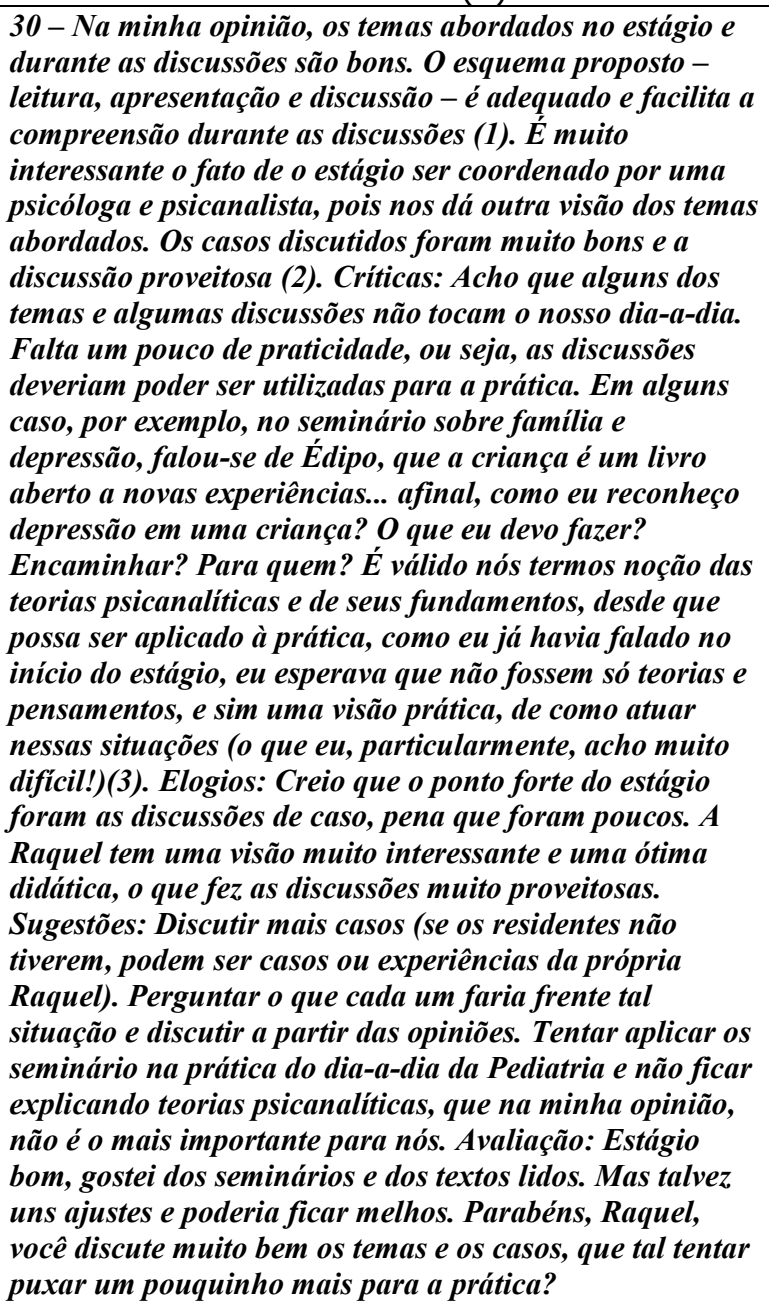 & $\begin{array}{l}1^{\text {a }} \text { idéia: Os textos utilizados são pertinentes } \\
\text { aos temas e suscitam questionamentos, } \\
\text { reflexões e críticas. } \\
2^{a} \text { idéia: As discussões de casos foram muito } \\
\text { proveitosa. } \\
3^{a} \text { idéia: Acho que devem ser discutidos } \\
\text { métodos práticos de consulta de crianças com } \\
\text { problemas psicológicos. }\end{array}$ \\
\hline $\begin{array}{l}31 \text { - Acho que este curso dado durante a } \\
\text { residência, de importância capital, } \\
\text { principalmente porque é um campo não muito } \\
\text { aprofundado durante a graduação (1). A saúde } \\
\text { mental da criança é um segmento que deve ser } \\
\text { pensado e estudado por todo pediatra que } \\
\text { deseje clinicar, usando uma abordagem global } \\
\text { e integral à saúde da criança. Essa importância } \\
\text { se torna ímpar quando se leva em consideração } \\
\text { que o pediatra tem na Puericultura uma } \\
\text { oportunidade de integrar-se a a } \\
\text { desenvolvimento e formação do futuro adulto. } \\
\text { Para que possa fazer Puericultura realmente }\end{array}$ & $\begin{array}{l}\text { 1a idéia: O curso apresenta uma proposta } \\
\text { sobre temas de extrema relevância que não } \\
\text { são aprofundados durante a graduação e a } \\
\text { residência. } \\
2^{a} \text { idéia: A saúde mental da criança é } \\
\text { fundamental para a abordagem integral do } \\
\text { pediatra, principalmente na puericultura. } \\
3^{a} \text { idéia: Tenho interesse em estudar mais } \\
\text { autores e temas e gostaria que houvesse } \\
\text { discussões periódicas. }\end{array}$ \\
\hline
\end{tabular}




\begin{abstract}
abordando a saúde da criança, é fundamental que a saúde mental seja levada em consideração. Para isso é importante se conhecer e estudar o psiquismo da criança e daqueles que sobre ela atuam. Mesmo no ambiente da residência, poucos são os lugares e as oportunidades que o residente tem de se aprofundar no mundo que se abre ao iniciarmos o estudo do psiquismo em formação da criança (2). Realmente, gostei muito do curso e me arrisco a dizer que, tendo em vista a riqueza de influências a que a criança está sujeita, este curso poderia ser estendido, sem o risco de se tornar repetitivo ou vazio.(3)
\end{abstract}

32 - Textos: a leitura de alguns textos foi $1^{\text {a }}$ idéia: A leitura dos textos foi difícil, no difícil, pois não estava habituada a este tipo de início, mas com a evolução do curso, foi linguagem; a maioria do conteúdo teórico que possível acompanhar melhor.

temos contato é tecnicista, com linguagem 2a idéia: Achei importante a disponibilidade da científica. Em determinados textos, senti que coordenadora em aceitar sugestões, de acordo para seu entendimento era necessário o com a demanda dos residentes.

domínio de alguns conceitos que até então, eu $3^{a}$ idéia: Foi essencial refletir e compartilhar não possuía. No entanto, a leitura foi opiniões, sentimentos e experiências com o proveitosa, tanto para o exercício de grupo.

preparação de textos com tal dificuldade, como $4^{a}$ idéia: Meu conhecimento evoluiu muito a pelos novos conhecimentos adquiridos(1). partir do curso: recebi informações novas e Considerei importante a sua disponibilidade em aprendi a pensar sobre assuntos que não aceitar sugestões, conforme a demanda dos estava acostumado.

residentes, como foi o caso do tema "adoção" $5^{a}$ idéia: Acho que devem ser discutidos (2). Discussões: gostei da forma de métodos práticos de consulta de crianças com apresentação dos textos, que por ser informal, problemas psicológicos.

dá liberdade para os demais expressarem suas opiniões sobre o conteúdo e trocar idéias.(3) Aplicabilidade clínica: os temas abordados me levaram a fazer reflexões que nunca havia pensado e a formar algumas opiniões. Acredito que muito do que aprendi me acrescentou primeiro como pessoa do que como médico, mas que inevitavelmente repercutirá no último.(4) No entanto, nesta fase de nossa formação o nosso maior anseio é a aplicabilidade clínica do que aprendemos e necessitamos que esta aplicação seja concreta, vivenciada. Tenho muita dificuldade em abordar determinados aspectos da saúde mental da criança e como conduzi-los. Foi muito interessante quando discutimos um caso clínico (do paciente de um residente), mas nem sempre temos esta demanda. Gostaria de deixar como sugestão que você trouxesse para a discussão alguns casos que considerasse ilustrativos e assim termos mais discussão clínica. (5)

33 - Considero não muito apto para falar muito $1^{\text {a }}$ idéia: Não me considero apto a falar sobre o deste estágio. As discussões que participei (3) estágio, pois participei de poucas discussões, foram razoáveis (1): a sobre mídia, perdi a que foram razoáveis.

primeira parte devido minhas férias, a parte que participei se resumiu a falar que a mídia (televisão) era algo terrível que "deixava o homem sentado e sem reação, impossibilitando-o de ter suas próprias idéias e de questionar o que é exposto". Não concordo 
inteiramente com isso. Não é a posição que a pessoa assume perante algo que a impeça de pensar ou ter suas próprias idéias. Cada veículo de comunicação tenta impor aos seus alvos suas idéias, mas este veículo não é único e em cada um há uma diferente idéia. A discussão sobre fracasso escolar não se aprofundou muito no tema; algumas pessoas se exaltaram em demonstrar idéias contrárias às cotas para negros em universidades públicas e também em demonstrar seus preconceitos contra as classes menos favorecidas economicamente. A discussão do assunto proposto se resumiu à leitura de um resumo do texto

34 - O estágio foi interessante no sentido de discutirmos temas importantes e pouco abordados na graduação e na residência médica (1). A leitura de textos e artigos é proveitosa para que todos fiquem a par do que está sendo discutido, e se possa formar opiniões mais consistentes. Creio, que apesar de muito bem conduzidas, as discussões poderiam ser mais bem aproveitadas com a utilização de recursos mais práticos, como vídeos e relatos de caso trazidos à aula. Às vezes, fica difícil trazer casos dos residentes que sejam compatíveis com o que está sendo abordado.(2) Outras atividades como simulações e questionários sobre o tema também aprimorariam os debates (5). Um ponto positivo é a possibilidade de nós, residentes, também nos expressarmos em relação aos nossos sentimentos para com a etapa da vida em que estamos atravessando. Permite um desabafo e uma orientação do caminho a seguir.(3) Assim, creio que o estágio permite que passemos, apesar do pouco tempo, por discussões inéditas, que ajudam, em minha opinião, a enxergar a residência, os pacientes e a nós mesmos de maneira mais clara (4).

35 - Acho que o estágio foi muito válido, já $1^{\text {a }}$ idéia: A Saúde Mental da criança é que atualmente enfrentamos cada vez mais na fundamental para a abordagem integral do prática clínica, problemas da ordem da saúde pediatra.

mental.(1) Os temas abordados foram $2^{\text {a }}$ idéia: Os textos utilizados ilustram bem os pertinentes e os textos deram um boa base temas propostos.

teórica para as discussões. As discussões foram $33^{\text {a }}$ idéia: Seria interessante discutir mais casos bastante válidas.(2) Acho que poderiam ser de crianças com distúrbios de comportamento, discutidos mais casos clínicos para ilustrar, na pois não sabemos como abordar.

prática, os temas discutidos.(3) Participei de $4^{\text {a }}$ idéia: Os temas foram relevantes e abriram poucas reuniões, mas pessoalmente eu gostei uma perspectiva nova para pensar o trabalho muito e me surpreendi, já que eu tinha um médico.

pouco de resistência para abordar estes assuntos. Isso mostra que estas atividades são importantes para "abrir" a visão do médico, que geralmente, é muito organicista.(4)

36 - Achei os textos muito interessantes, $1^{\text {a }}$ idéia: Acho que deveriam ser discutidos principalmente o relacionado à televisão e à métodos práticos de consultas de crianças com adoção, o horário é bem flexível e as problemas psicológicos. 


\begin{abstract}
discussões foram úteis para a prática. $A$ sugestão que faço seria estabelecer um horário para toda aula discutirmos um caso. Se, por ventura, não for trazido pelos residentes, poderia ser do I.Cr., visto que no nosso estágio foram insuficientes, por falta de assunto. Tivemos poucas discussões, mas que foram suficientes para mostrar sua efetividade na prática médica (1). A princípio, os textos foram de difícil compreensão, mas depois que concluíamos as discussões, ao reler, esse se tornava mais simples e compreensível (2). Os assuntos abordados foram bem escolhidos $e$ abordaram assuntos da realidade.
\end{abstract}

37 - Considero que o curso foi muito bom, já que consistiu num espaço aberto para discutirmos Saúde Mental e até para voltarmos a pensar sobre a escolha da profissão e da especialidade Pediatria. Gostei também da primeira discussão, pois apesar de convivermos muitas horas juntos durante o ano, ainda existem coisas que desconhecemos dos colegas e talvez se soubéssemos mais uns sobre os outros poderíamos tornar a residência mais "leve" e mais solidária (1). A proposta da divisão do tempo também é válida e acho que se possível, deve ser mantida a discussão de pelo menos um caso/manhã, pois com exemplos, a aplicação prática se torna mais "palpável" para nós.(2) A abordagem dos temas é pertinente e traz reflexões sobre situações atuais que são vividas freqüentemente, porém nem sempre entendidas por nós, como por exemplo, a nova "formação" das famílias com a mulher como provedora e o homem cuidador, ou até mesmo os casais homossexuais; o melhor entendimento da depressão e da influência da mídia sobre a criança... (3) porém senti falta de temas contemplando o desenvolvimento psicossocial da criança para que possamos avaliá-la melhor e identificar precocemente os casos necessários (4). Sem dúvida, o estágio foi muito proveitoso e para mim atingiu o objetivo de tentar identificar as famílias e crianças que poderiam se beneficiar com uma atuação não somente "patológica ou orgânica" de minha parte ou até com o encaminhamento para um profissional mais habilitado que eu nessa área.(5)

38 - De início, pensei se tratar de curso $1^{\text {a }}$ idéia: o curso apresenta uma proposta teórico, onde aprenderíamos técnicas "psi" para inusitada, não- convencional.

lidar com diversos assuntos (violência, adoção, $2^{\mathrm{a}}$ idéia: O curso apresenta uma proposta sobre papéis materno e paterno...) muito comuns na temas de extrema relevância que não são prática pediátrica. Percebi, no entanto, que se aprofundados durante a graduação e a tratava de coisa muito diferente de um residência.

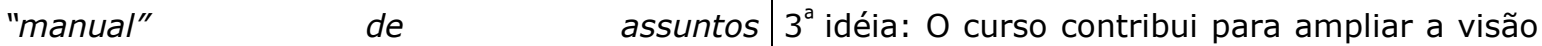
psicológicos/psiquiátricos. Surgia a da Pediatria, identificar e atuar sobre os oportunidade de ler textos, algumas vezes aspectos psíquicos do paciente, para além do controversos, muitas vezes também orgânico.

extremamente subjetivos, mas que colocavam $4^{\mathrm{a}}$ idéia: 0 curso é necessário e está bem devidamente os assuntos em pauta. E as mais colocado no programa de residência. 


\begin{abstract}
variadas opiniões e observações sobre os temas em questão apareciam.(1) Muitos dos temas, pelo menos para mim, nunca haviam sido abordados durante a graduação (p.ex., o suicídio na infância e adolescência, fato que me chocou de certa forma) e contribuíram para aumentar a minha visão do ser biopsicossocial (esse sim, tão falado na faculdade, mas tão pouco abordado, de fato) (2). O curso, como um todo, apesar do cansaço dos pós-plantões (perdoe nossas "pescadas" durante o período), contribuiu em muito para ampliar a visão na pediatria geral, abrir oportunidades de avaliar coisas além do "peso-altura-mamadeira-cocôqueixas orgânicas" e nos incentivou a buscar coisas além da chamada "consulta de rotina", como a relação entre os pais e destes com seus filhos, os papéis desempenhados em casa, a abordagem da violência doméstica, dentre outros(3), e foi bem inserido durante o módulo de Pediatria Comunitária, onde a clientela atendida (na maioria moradores da favela próxima) nos ilustrava as várias questões abordadas (4). De uma maneira bem simplista, poderia dizer que gostei bastante e acho que aproveitei o que podia (5).
\end{abstract}

39 - Na minha opinião, muitos aspectos podem ser apontados sobre este curso. Foi muito interessante entrar em contato com outro profissional da saúde da criança que tivesse uma formação não-médica. Deste contato, pudemos conhecer outros modos de interpretação dos problemas comuns que encontramos na clínica pediátrica e que, infelizmente, não são muito valorizados na nossa formação acadêmica, que acaba sendo muito técnica e, paradoxalmente, pouco humanizada (1). No curso pude discutir um pouco sobre assuntos básicos como família e sua função, violência, mídia, fracasso escolar, entre outros, mas pude também rever meus próprios preconceitos e notar como estes afetam meus sentimentos e minhas condutas (2). Além disso, considero muito importante poder discutir um pouco sobre as dificuldades que estava vivendo nesta experiência de médico-residente, em que tudo era novidade e trazia certos conflitos. Foi reconfortante notar que meus colegas passavam por conflitos parecidos, e que não estava sozinho (3). Confesso que foi muito difícil lidar com textos que traziam questões gerais, porém apresentadas de forma totalmente diferente da que estava acostumada na graduação.

Algumas vezes, foi complicados encontrar motivação, pois quando entramos na residência, estamos sedentos por conhecimento técnico, estando totalmente despreparados para este tipo de texto (4). Acredito que este curso ajudou a me formar um pediatra mais consciente de meus próprios preconceitos e talvez menos impulsivo na hora de julgar as informações, sintomas e sinais, e por que não, o próprio paciente e sua família . Considero este curso algo peculiar, numa formação tão tecnicista $e$ impessoal.(5) $5^{a}$ idéia: Gostei bastante do curso.

(1)

$1^{\text {a }}$ idéia: O curso apresenta uma proposta sobre temas de extrema relevância que não são aprofundados durante a graduação e a residência.

$2^{\mathrm{a}}$ idéia: $\mathrm{O}$ curso permite conhecer melhor a nós mesmos.

$3^{\mathrm{a}}$ idéia: Foi essencial refletir e compartilhar opiniões, sentimentos e experiências com o grupo

$4^{a}$ idéia: A leitura dos textos foi difícil, no início, mas com a evolução do curso é possível acompanhar melhor.

$5^{a}$ idéia: 0 curso apresenta uma proposta inusitada e não-convencional.

40 - Quando da programação inicial do estágio, $1^{\text {a }}$ idéia: O curso apresenta uma proposta sobre fiquei um pouco apreensiva pensando que seria temas de extrema relevância que não são um estágio objetivo e mecânico sobre aprofundados durante a graduação e a 
patologia, tipo: diagnóstico e tratamento em residência.

saúde mental da criança. Quando recebi a $2^{\text {a }}$ idéia: As férias durante o curso prejudica programação das aulas achei os temas bem bastante o aprendizado dos conceitos, pois há interessantes e bem amplos, onde teríamos uma lógica na seqüência dos temas.

oportunidades para entender e discutir sobre $3^{\mathrm{a}}$ idéia: Gostaria que houvesse discussões questões que como pediatra geralmente não periódicas.

temos acesso e nem base para enfrentar, como situações novas de família: pais homossexuais, pais sozinhos que cuidam dos filhos, pai que faz papel de mãe e vice-versa. Outros temas interessantes foram: criança e mídia, adoção, violência, depressão, relação médicopaciente(1). Os textos dados foram abrangentes, a forma de discussão funciona bem melhor que aula magistral e as pontuações da Raquel são essenciais para a compreensão de tudo que o texto tem para passar. Infelizmente, muitos de nós somos obrigados a tirar férias durante o estágio de Pediatria Comunitária e saímos perdendo, pois ambulatório, enfermaria, PS, sempre é possível repor e essas discussões são únicas nesta fase de nossa formação (2). Tive uma visão muito positiva do curso e acho que as discussões deveriam se estender por todo ano e se possível, como todos os residentes juntos, poderia ser feito uma vez por mês no mesmo horário das aulas de Ped. Comunitária (3).

41 - Há muito já se reconheceu a relevância da Psicologia na compreensão e no tratamento de enfermidades orgânicas que desencadeiam doenças mentais. Mas a nova Pediatria, particularmente, está dando enfoque aos aspectos do desenvolvimento psíquico infantil e a relação com a doença. A união da Pediatria à Psicologia é perfeita pela necessidade de se ter uma visão holística do ser humano. Por mais que as especialidades da Medicina sejam relevantes, os especialistas atuais não devem se afastar da situação global do indivíduo. Perceber o paciente em toda a sua dimensão é o que existe de mais moderno, sensato e humano nos dias de hoje (1). Principalmente na Pediatria, já que os primeiros anos de vida são básicos para a estruturação psíquica do indivíduo. Assim sendo, as condutas e as orientações que possam assegurar uma correta higiene mental são mais importantes na vida infantil do que na vida adulta (2). Relacionar-se com uma equipe multidisciplinar é uma exigência da Medicina atual, porque a descoberta da real dor humana passa pelo cultural, pelo social, pelo econômico, pelo biológico e pelo psíquico (3). Reconhecer o componente psíquico no contexto patológico é tomar trilhas sensatas no objetivo de curar (1). Não é à toa que a OMS propôs o significado da palavra "saúde" como "um estado de bemestar físico, mental e social" e não apenas luta contra a doença e a morte. Além do mais, as crianças têm características psíquicas que Ihes são muito peculiares e que as distinguem dos adultos. A criança percebe determinados fatos, 


\begin{tabular}{|c|c|}
\hline $\begin{array}{l}\text { segundo uma compreensão própria diferente } \\
\text { daquela dos adultos. Por tudo o que já foi dito, } \\
\text { ressalto a importância de nós, pediatras termos } \\
\text { esse enfoque psicossocial da Medicina e } \\
\text { particularmente da criança, em que o médico } \\
\text { junto com o psicólogo ultrapasse os limites do } \\
\text { tratamento em função da cura e promova a } \\
\text { "psico-higiene", tomando atitudes mais } \\
\text { profiláticas, preventivas e comunitárias, em } \\
\text { busca do bem-estar do paciente como um todo. }\end{array}$ & \\
\hline $\begin{array}{l}42 \text { - Achei as discussões muito boas, nas quais } \\
\text { pudemos "esmiuçar" os textos e toda a sua } \\
\text { subjetividade. Nem todos foram claros para } \\
\text { mim e de certa forma foi importante para } \\
\text { aprender a treinar minha compreensão sob } \\
\text { outras abordagens (1). Creio que fizeram com } \\
\text { que pensássemos em tópicos que não veríamos } \\
\text { nos módulos convencionais da residência (2). } \\
\text { É muito importante aprender sobre o que se } \\
\text { passa nas mentes tratadas e não só nos corpos } \\
\text { físicos. Raquel teve abordagem fácil de ser } \\
\text { compreendida e apesar de toda a subjetividade } \\
\text { dos temas, tudo fica de certa forma, muito } \\
\text { claro (3). Acho que os textos sempre devem } \\
\text { ser acompanhados das discussões, pois se não } \\
\text { há essa troca, perdemos grande parte do seu } \\
\text { conteúdo. Acabei perdendo } 3 \text { temas por causa } \\
\text { das férias e sugiro que haja um meio de que } \\
\text { isso não ocorra nas outras turmas, pois } \\
\text { acabamos perdendo a metade do programa } \\
\text { (4). }\end{array}$ & 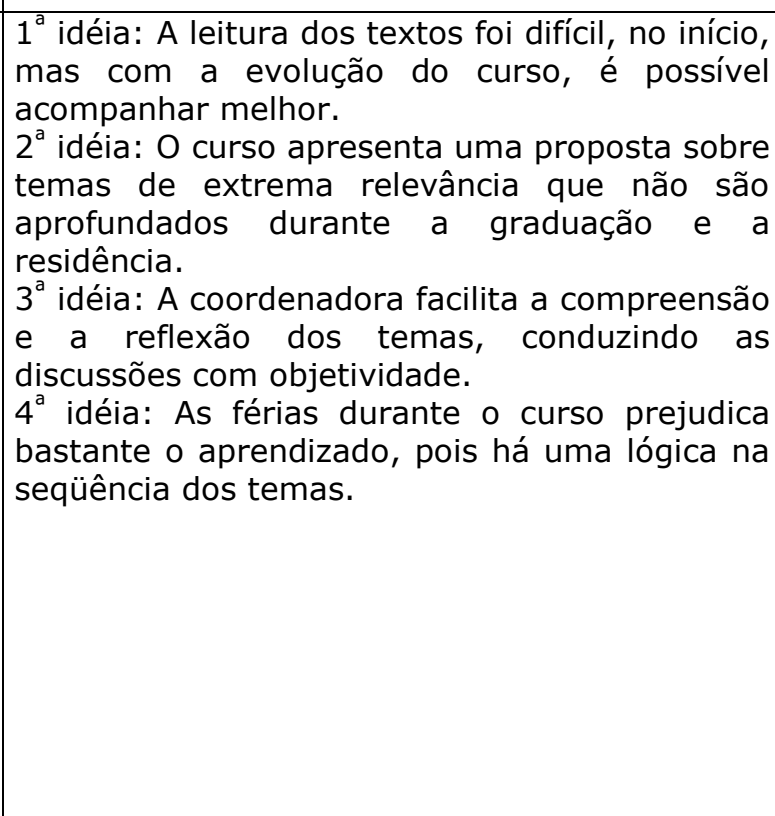 \\
\hline $\begin{array}{l}43 \text { - Em minha opinião o curso de saúde } \\
\text { mental da criança teve grande importância em } \\
\text { minha formação e, com certeza, influenciará } \\
\text { em minha prática pediátrica futura. Discutimos } \\
\text { assuntos que envolvem toda a vida e a história } \\
\text { da criança. A criança é um ser em } \\
\text { desenvolvimento físico, mental, emocional, } \\
\text { social etc e está sujeito a influências do meio. } \\
\text { Por isso, é necessário conhecer e avaliar tudo o } \\
\text { que envolve a vida da criança, o contexto } \\
\text { familiar no qual essa criança está inserida, sua } \\
\text { vida social, seus contatos, suas atividades } \\
\text { diárias e como ela é capaz de lidar com } \\
\text { situações novas e, às vezes, hostis. Todos os } \\
\text { profissionais que trabalham com crianças, } \\
\text { incluindo o pediatra, devem conhecer as } \\
\text { diversas formas e, talvez, sintomas que as } \\
\text { crianças se utilizam para expressar seus } \\
\text { sentimentos, suas angústias, seus medos, suas } \\
\text { alegrias, seus gritos de ajuda ou } \\
\text { independência. A criança é um indivíduo que } \\
\text { está formando sua personalidade e tudo o que } \\
\text { acontecer em sua vida ou ao seu redor neste } \\
\text { período, aú } \\
\text { inconscientemente, positiva ou negativamente, } \\
\text { na formação de sua personalidade. Desta } \\
\text { forma, acredito que este curso me ajudou a } \\
\text { entender um pouco do que influencia a vida da } \\
\text { criança e de como a criança pode expressar } \\
\text { essas influências(1). A dinâmica através da }\end{array}$ & 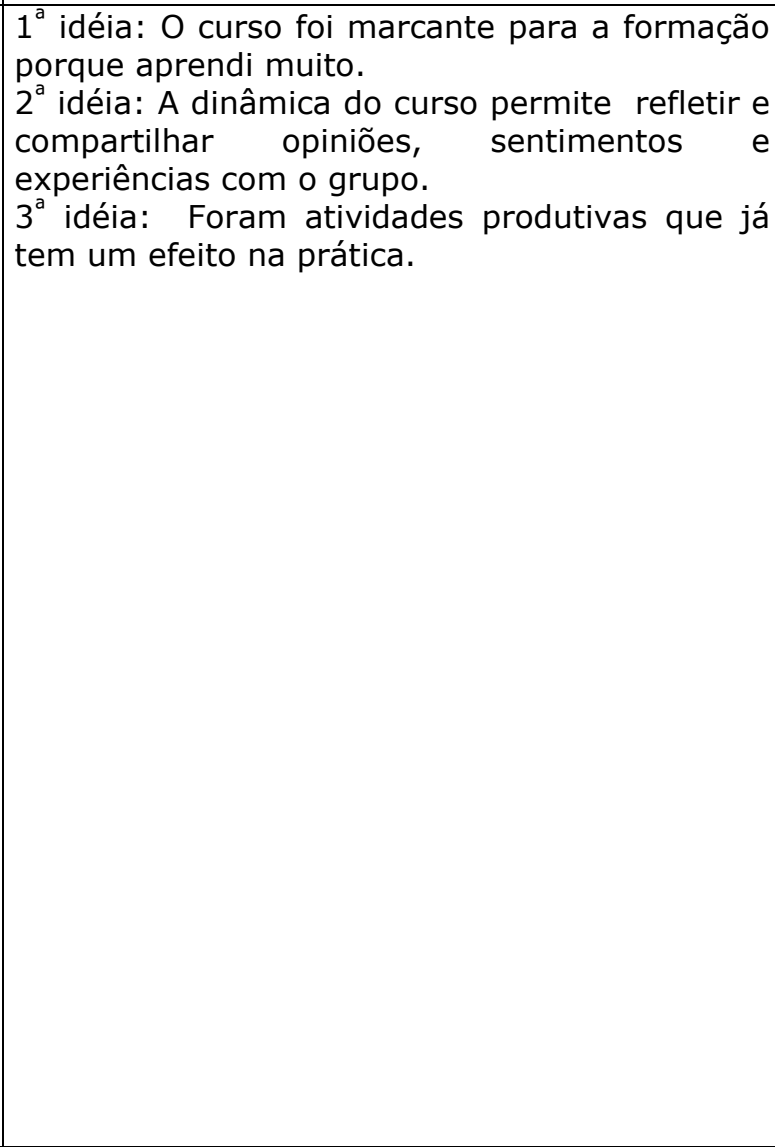 \\
\hline
\end{tabular}


qual o curso foi exposto também foi muito bom porque lemos sobre um determinado assunto que nos faz pensar sobre o tema e sobre os conceitos e pré-conceitos que temos sobre eles e durante a discussão no grupo reforçamos esses conceitos, excluímos alguns préconceitos e aprendemos como a criança pode ser influenciada por ele (2). O curso de saúde mental da criança me ajudou e me ajudará a entender e a perceber de forma diferente algumas situações e sintomas apresentados pelas crianças que tenho e terei contato em minha prática pediátrica (3).

44 - Realmente gostei muito dos nossos encontros sobre saúde mental(1). Eles me $1^{\text {a }}$ idéia: Gostei muito do curso.

ajudaram a enxergar a Pediatria sob um prisma $2^{\text {a }}$ idéia: 0 curso apresenta uma proposta diferente, trabalhando questões "novas" e de inusitada e não convencional.

uma forma não-habitual.(2) Desde que as $3^{\text {a }}$ idéia: Foram atividades produtivas que já discussões se iniciaram tenho tido um olhar tem um efeito na prática.

mais crítico sobre cada queixa trazida pelas $4^{\text {a }}$ idéia: Gostaria que houvesse discussões mães ou pelas próprias crianças nas periódicas, pois tenho interesse em estudar consultas... No meu caso, em particular, as mais autores e temas.

discussões me permitiram conhecer um possível campo de atuação para o futuro, uma vez que despertaram em mim um grande interesse por essa área (3) (despertaram "meu Freud interior"). De qualquer forma, achei muito importante para minha formação como pediatra (e para o meu crescimento como ser humano) e acho que seria muito importante a continuação desse trabalho, afinal 10 semanas é muito pouco tempo... (4) Parabéns!

45 - 0 curso de saúde mental foi uma $1^{\text {a }}$ idéia: O curso apresenta uma proposta sobre experiência nova para mim. A oportunidade de temas de extrema relevância que não são debater temas como a estruturação da família, aprofundados durante a graduação e a violência, adoção etc, no curso de residência foi residência.

uma surpresa, já que nossa formação está $2^{a}$ idéia: O curso proporcionou uma abertura mais direcionada para as patologias puramente para mudanças e questionamentos.

"orgânicas". Como pude concluir no decorrer do $3^{\text {a }}$ idéia: Gostei muito deste estágio.

curso, esses temas são importantíssimos, pois

a consulta pediátrica envolve muito a parte psicossocial da criança.(1) A seqüência de temas debatidos foi muito bem organizada. Um outro aspecto foi entrar em contato com textos de outras áreas como Psicologia/Psicanálise, muitas vezes textos difíceis de serem lidos. Porém, acho interessante poder entrar em contato com esses textos que nos "abrem horizontes", pois não o faria espontaneamente (2). Enfim, gostei muito deste estágio, embora acho que não aproveitei $100 \%$, devido aos meus vários plantões de quinta à noite (3).

46 - Não sei bem por onde começar... Achei o $1^{\text {a }}$ idéia: O curso proporcionou uma abertura curso de saúde mental muito proveitoso. Foi para mudanças e questionamentos.

uma das atividades do estágio de Pediatria Comunitária que abriu a cabeça, jogou conceitos velhos fora e fez agente realmente pensar (o que falta um pouco nos outros estágios da residência). (1) A bibliografia foi ótima, mesmo os textos não-médicos (e portanto, um pouco confusos para nós) foram muito interessantes e deu para aproveitar 


\begin{tabular}{|c|c|}
\hline bastante. Só tenho elogios! & \\
\hline $\begin{array}{l}47 \text { - Antes de começar o curso, não tinha } \\
\text { muito idéia sobre exatamente o que seria } \\
\text { abordado nesse estágio. Como comecei o } \\
\text { estágio após } 2 \text { semanas dos meus colegas (por } \\
\text { motivo de férias), me disseram que eu teria } \\
\text { que me apresentar. Já não me simpatizei muito } \\
\text { com essa idéia em ter que me expor, falar } \\
\text { sobre eu mesma, sobre meu passado, } \\
\text { ansiedade, expectativas e desejos... e ainda na } \\
\text { frente de outras pessoas! Tive um certo "pré- } \\
\text { conceito" diante desse estágio. O engraçado é } \\
\text { que logo na primeira aula, me identifiquei com } \\
\text { toda a dinâmica da panela. Os temas } \\
\text { abordados são temas muito pertinentes ao } \\
\text { nosso dia-a-dia, são problemas que nos } \\
\text { deparamos todos os dias em nosso trabalho. E } \\
\text { o interessante é que muitas vezes não paramos } \\
\text { para pensar ou refletir (1). O que chama } \\
\text { atenção é como ocorrem os debates sobre os } \\
\text { temas, às vezes fugindo totalmente do assunto } \\
\text { e entrando em outro, de acordo com a nossa } \\
\text { necessidade, dúvidas e vivências. Esse estágio } \\
\text { é extremamente necessário em nosso } \\
\text { programa de residência, pois a residência é } \\
\text { vivida em um ambiente estressante, em que } \\
\text { somos considerados uma mão-de-obra para } \\
\text { "tocar o serviço" onde se desenvolve muito a } \\
\text { ciência e se esquece um pouco o lado humano, } \\
\text { que por trás do residente existe um ser como } \\
\text { qualquer ser humano com medos e angústias e } \\
\text { que está disposto a resolver o problema de seu } \\
\text { paciente que vem te procurar na maioria das } \\
\text { vezes, fragilizado, inseguro e temendo sobre } \\
\text { alquma desarmonia biopsicossocial(2). }\end{array}$ & 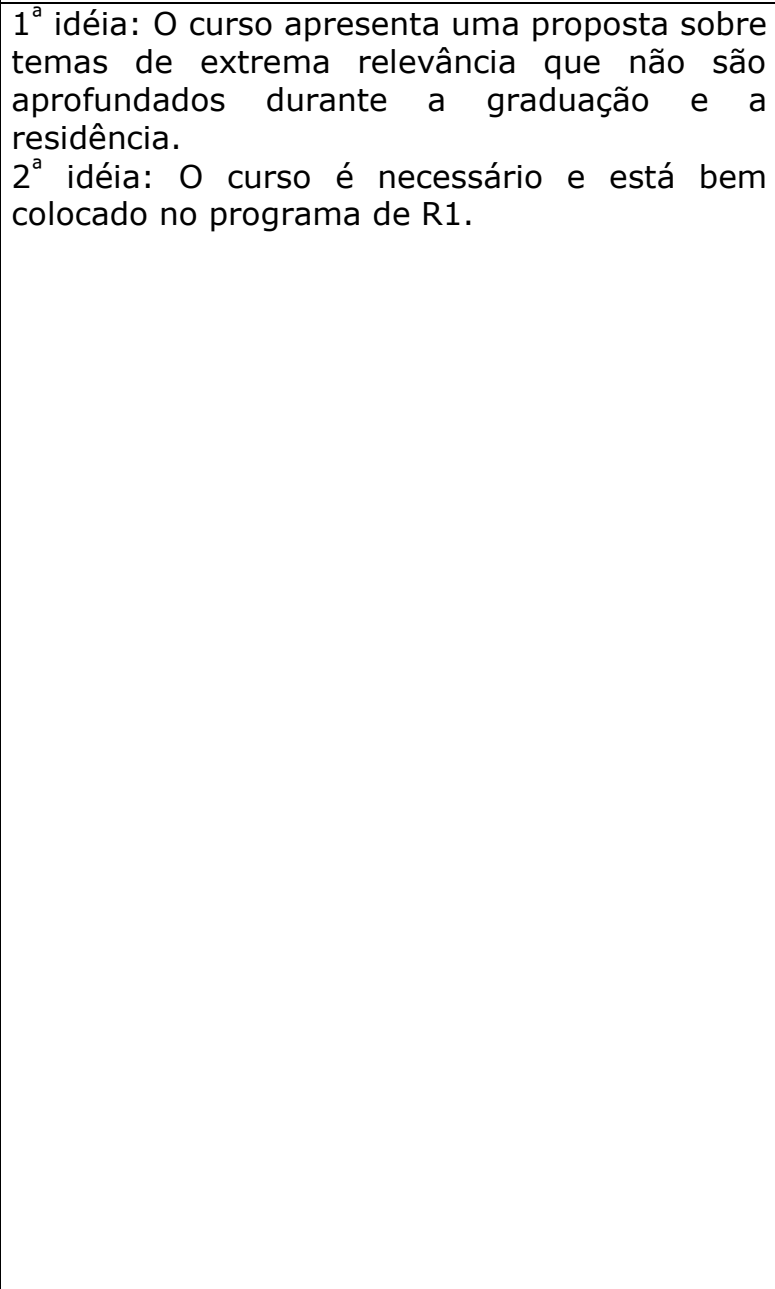 \\
\hline $\begin{array}{l}48 \text { - A atividade, ao meu ver, atingiu sua } \\
\text { proposta de discutir e pensar em temas atuais } \\
\text { e importantes da saúde mental da criança. } \\
\text { Trabalhou a avaliação da criança como um } \\
\text { todo, soma de si mesma e do meio que a } \\
\text { cerca. Abordou temas difíceis, polêmicos e } \\
\text { atuais como depressão, violência, mídia, } \\
\text { fracasso, escolar, adoção; temas importantes e } \\
\text { presentes nas nossas atividades práticas } \\
\text { ambulatoriais e muitas vezes não abordados } \\
\text { por serem difíceis, por falta de conhecimento } \\
\text { sobre o assunto, pela sensação de não- } \\
\text { resolutividade - quando, na verdade, nosso } \\
\text { papel muitas vezes será apenas de esclarecer e } \\
\text { orientar, muita pretensão querer resolver o } \\
\text { problema de todos.(1) Achei de extrema } \\
\text { importância esta atividade, e apesar de } \\
\text { "subjetiva", não se perdeu, por ter sido } \\
\text { trabalhada com muita seriedade e pela } \\
\text { abordagem, sempre embasada em textos, o } \\
\text { que sedimentou melhor os assuntos, ao meu } \\
\text { ver, durante as discussões.(2) }\end{array}$ & 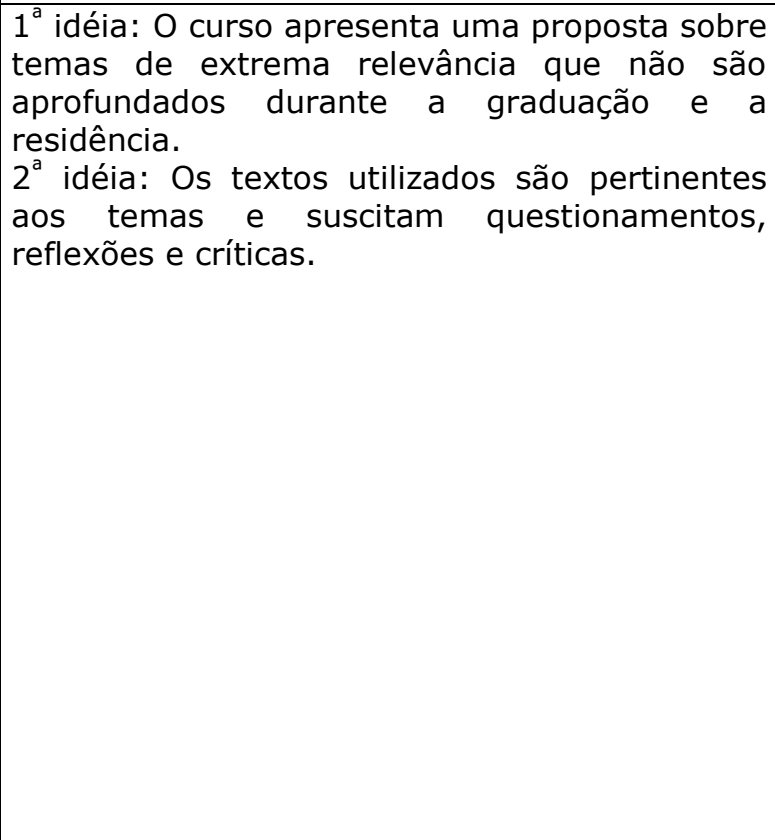 \\
\hline $\begin{array}{l}49 \text { - Devo dizer que minha avaliação só pode } \\
\text { ser parcial, devido às inúmeras ocasiões que } \\
\text { precisei ausentar-me. Mesmo assim, tive um } \\
\text { ganho imenso, não só em relação ao meu auto- } \\
\text { conhecimento, que enxergo agora como } \\
\text { fundamental para aprimorar minha relação }\end{array}$ & $\begin{array}{l}1^{\text {a }} \text { idéia: O curso permite conhecer melhor a } \\
\text { nós mesmos. }\end{array}$ \\
\hline
\end{tabular}




\begin{abstract}
interpessoal, tanto na minha vida particular, como principalmente, na minha vida profissional. Vejo agora que meu bem-estar é indispensável na tentativa de estabelecer qualquer vínculo com meus pacientes e seus responsáveis, desde a relação mais curta, como numa consulta de pronto-socorro, até o maior vínculo, necessário para um bom acompanhamento ambulatorial.(1) Gostaria de agradecer a todos os responsáveis pelo curso pela oportunidade de sair da rotina maçante de atendimento contínuo e olhar de fora para os eventos prévios e analisá-los como forma de tecer uma aprendizado a partir deles.
\end{abstract}

50 - Gostei muito do estágio.(1) Acredito ter $1^{\text {a }}$ idéia: Gostei muito do estágio.

aprendido muito, não só para a vida $2^{\text {a }}$ idéia: O curso apresenta uma proposta sobre profissional, como para a vida pessoal. Em temas de extrema relevância que não são conjunto com outros estágios do Centro de aprofundados durante a graduação e a Saúde, esse estágio contribuiu para pensarmos residência.

sobre assuntos que têm importância social. $3^{\text {a }}$ idéia: A abordagem global do ser humano só Para mim foi super-importante, sinceramente, ocorre no contexto multidisciplinar.

não esperava encontrar essa preocupação numa residência que de acordo com meus préconceitos, seguiria um padrão mais tradicional, simplificando o paciente a uma doen $\div$ a e não a uma pessoa como ele deve ser visto.(2) o fato de entrarmos em contato com outras profissões (psicólogas, pedagogas, enfermeiras) mostra como é ampla a atuação do pediatra e como é importante o trabalho multiprofissional durante o crescimento e desenvolvimento da criança. Não tenho dúvida da importância de integrar várias áreas (educação e saúde) e profissionais para a melhoria da qualidade de vida em qualquer lugar do mundo. E esse estágio só me deu mais certeza disso. Gostaria de ressaltar a importância dos agentes comunitários de saúde, que na minha opinião, pode ser a grande sacada no sentido de aproximar a população dos serviços de saúde(3). O mais difícil, talvez, seja individualizar os ganhos de cada estágio. O de saúde mental ajudou muito no sentido do trabalho multiprofissional, abordando temas nem sempre fáceis de lidar na prática médica e que são problemas freqüentes, como a queixa de fracasso escolar, depressão etc.(3) Infelizmente o tempo é curto e não dá para abordar todos assuntos que eu gostaria, talvez uma sugestão é o tema desenvolvimento da criança, as teorias de Piaget, etc. Já que não sei nada a respeito.

51 - O módulo de Saúde Mental, dentro do $1^{a}$ idéia: O curso apresenta uma proposta sobre ensino da Pediatria Comunitária, foi realmente temas de extrema relevância que não são muito proveitoso. Pudemos discutir temas de aprofundados durante a graduação e a grande importância e muitas vezes presentes residência.

em nossas vidas ou na prática clínica, mas que $2^{\text {a }}$ idéia: A abordagem global do ser humano só em geral são vistos sob outros ângulos (1). ocorre no contexto multiprofissional.

Certamente, este enfoque é necessário se $3^{\text {a }}$ idéia: Gostaria que houvesse discussões quisermos compreender os indivíduos como um periódicas, pois tenho interesse em estudar todo, já que, em geral, as doenças são mais autores e temas. multifatoriais e certamente a parte "psi" tem 


\begin{tabular}{|c|c|}
\hline $\begin{array}{l}\text { rande importância (2). Os temas discutidos } \\
\text { ram extremamente interessantes e com } \\
\text { erteza, haveriam muitos outros a serem } \\
\text { iscutidos, caso o tempo disponível fosse } \\
\text { laior. Seria, então, muito interessante ter } \\
\text { utras oportunidades durante a residência para } \\
\text { ar continuidade a este trabalho.(3) }\end{array}$ & \\
\hline $\begin{array}{l}2 \text { - De todo o estágio da Pediatria } \\
\text { omunitária, a atividade que eu mais gostei foi } \\
\text { sta. É fundamental conhecermos um pouco da } \\
\text { rmação psíquica da criança, ler diversos } \\
\text { emas como violência e relação médico- } \\
\text { aciente. As discussões foram enriquecedoras, } \\
\text { le fizeram recordar os tempos em que fazia } \\
\text { nálise - alguns minutos para refletir. } \\
\text { evantamos questões que me suscitaram } \\
\text { entimentos e lembranças, esquecidas com a } \\
\text { orreria da residência (1). Acho esta atividade } \\
\text { xtremamente necessária, e senti que deveria } \\
\text { e estender durante o ano todo - com objetivo } \\
\text { ão apenas de abordar os aspectos psíquicos } \\
\text { as crianças, mas também dos residentes. Nós } \\
\text { assamos por muitas situações e não } \\
\text { ncontramos espaço para discuti-las. Apesar da } \\
\text { istência do GRAPAC, o que sugiro é uma } \\
\text { iscussão com o grupo - dividir as angústias e } \\
\text { úvidas, afinal estamos todos no mesmo barco, } \\
\text { pior, sem qualquer suporte psi.(2) }\end{array}$ & $\begin{array}{l}1^{a} \text { idéia: O curso proporciona uma abertura } \\
\text { para mudanças e questionamentos. } \\
2^{a} \text { idéia: As discussões deveriam se estender } \\
\text { por todo o programa para dar um suporte } \\
\text { psicológico aos residentes. }\end{array}$ \\
\hline 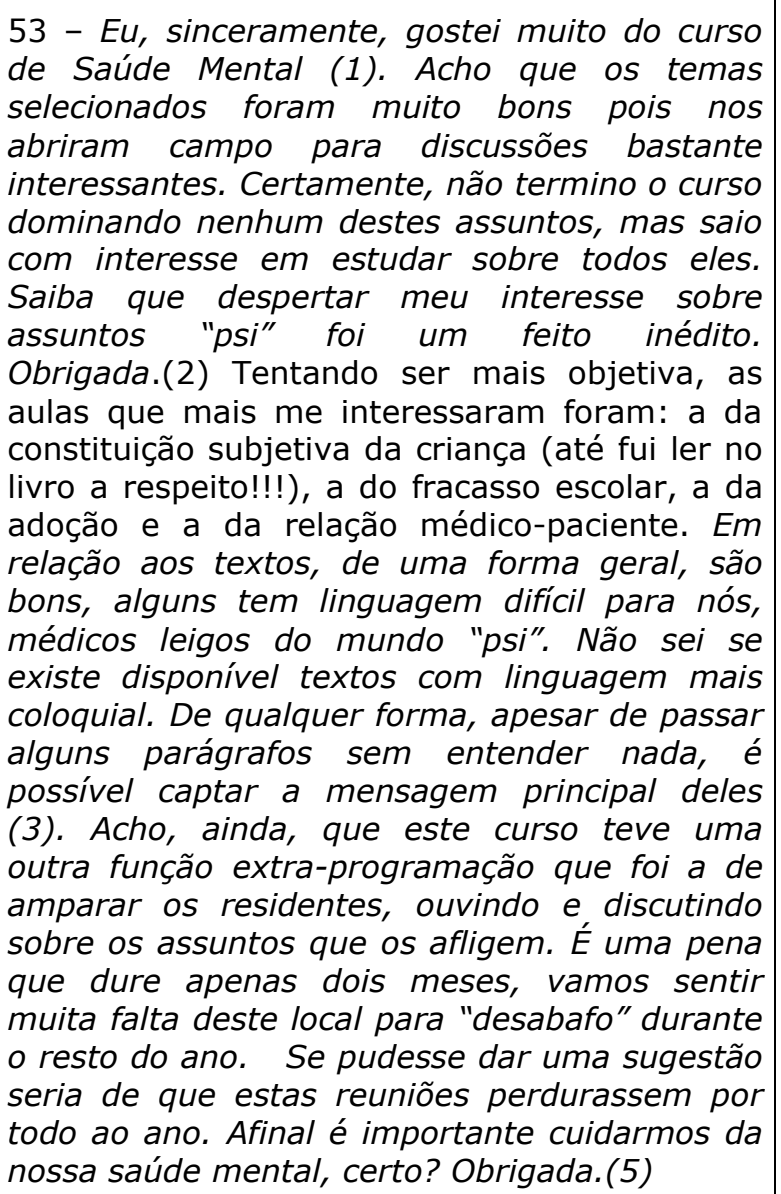 & 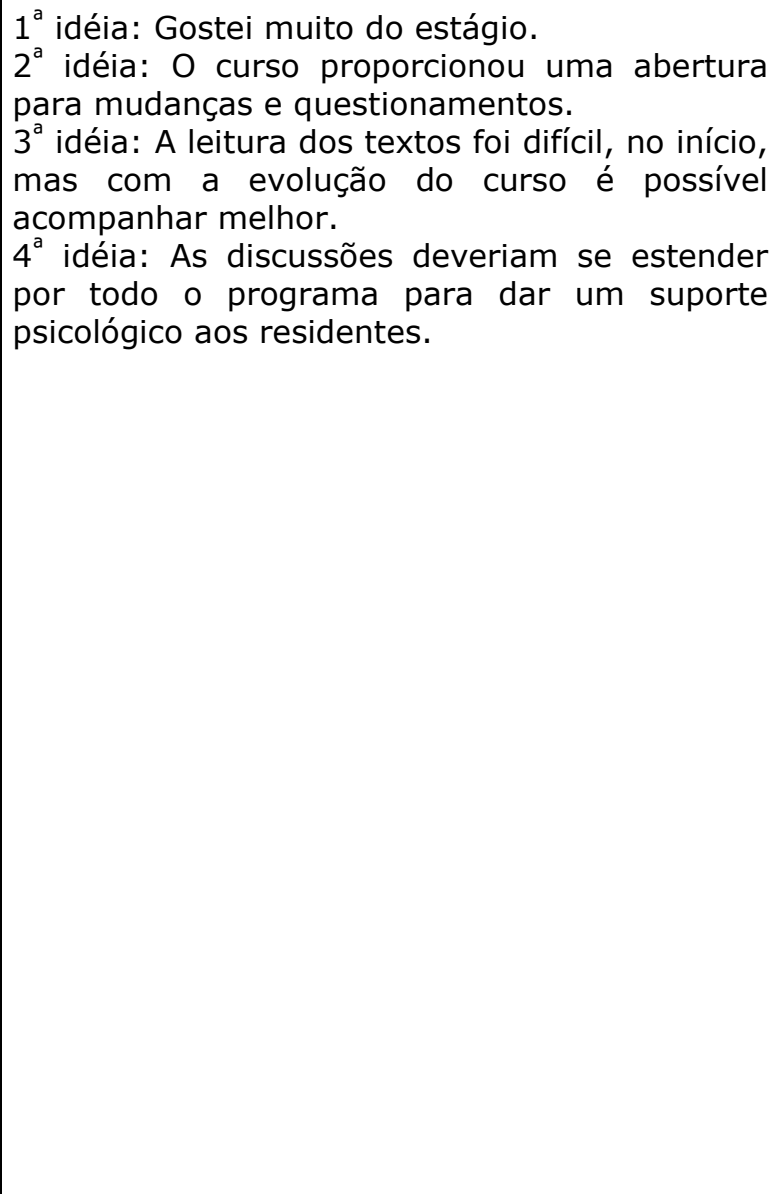 \\
\hline $\begin{array}{ccccc}- & \text { Durante } & \text { quatro } & \text { anos } & \text { passei } \\
\text { senvolvendo } & \text { atividades } & \text { de } & \text { ensino- }\end{array}$ & \\
\hline
\end{tabular}




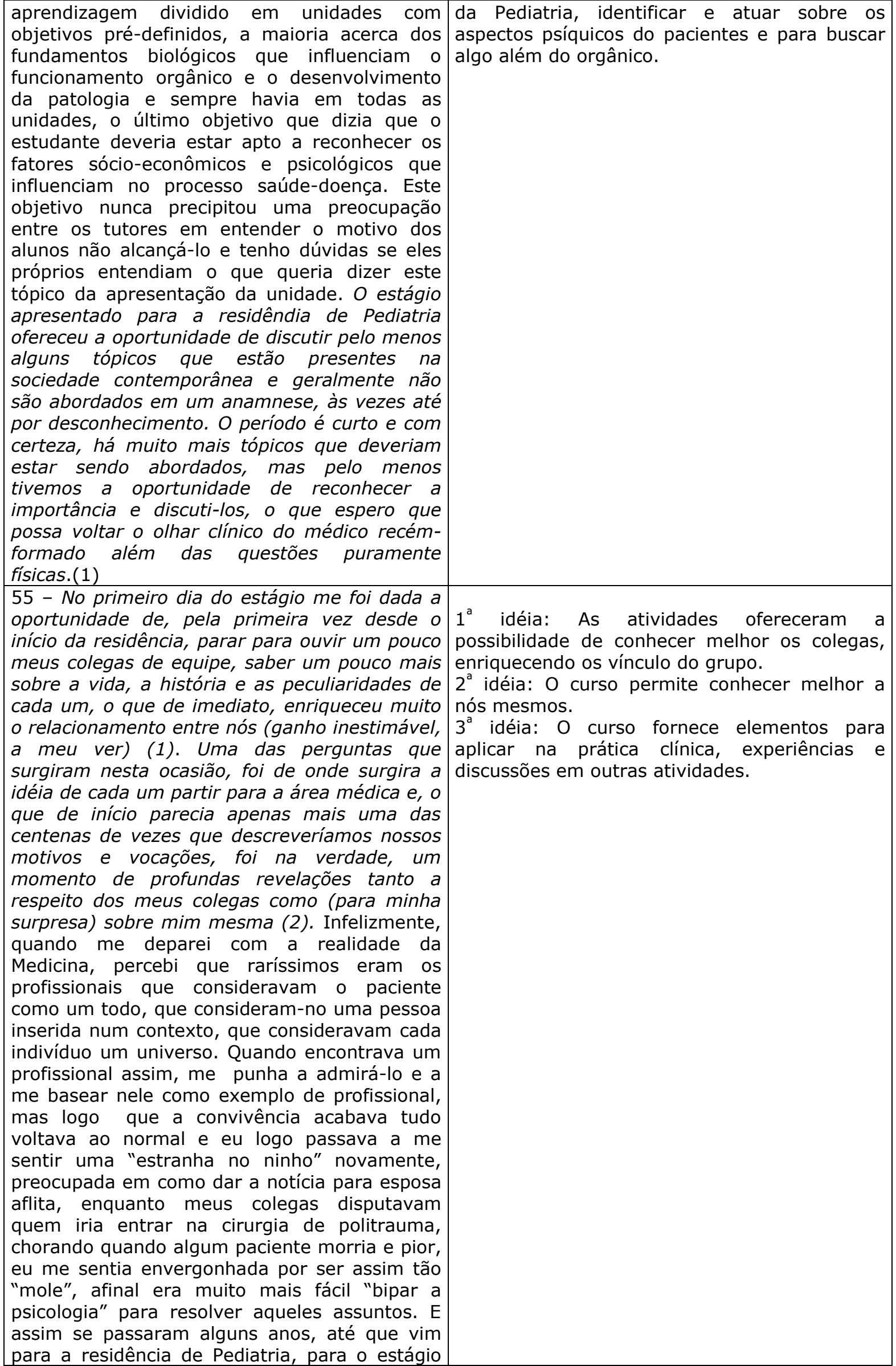


de Pediatria Comunitária, e para as reuniões semanais de sexta-feira, cujos temas me fizeram lembrar que apesar de nunca ter pensado em fazer Medicina até os 18 anos, eu sempre fora apaixonada pelo ser humano em sua essência, tanto no que diz respeito aos seus aspectos orgânicos como os individuais, psicológicos e subjetivos e que o problema é que eu ainda não havia descoberto uma maneira de unir esta minha paixão à prática médica que me havia sido ensinada pelos profissionais que passaram pela minha formação. Refletir sobre os temas que discutimos fortaleceu minha maneira de ver o paciente e de lidar com as diversas situações nas quais ele está inserido. Mas meu maior ganho mesmo foi perceber que cada vez mais a Medicina tem trazido para si a valorização do paciente como um ser único, como um indivíduo completo e que criar vínculos verdadeiros, preocupar-se, solidarizar-se, alegrar-se e até sofrer com e pelo paciente, não significa "ser mole" e sim exercer uma Medicina com muito mais sentido (3).

57 - Achei muito válido o contato que tivemos com a Psicologia infantil, pois não temos uma atenção específica do assunto no nosso dia-adia na residência (1). É muito complicado lidar com a insegurança em relação a problemas psicológicos durante a consulta pediátrica, tanto em relação à mãe quanto ao paciente. $A$ minha opinião é que a consulta não pode e não deve se restringir somente à queixa orgânica, por vários motivos. Primeiro porque essa queixa, conscientemente ou não, leva a uma angústia/dúvida/medo, tanto para a família, como às vezes, para a própria criança. Segundo que pode haver relação de causa e efeito entre a queixa e o aspecto psicológico. Por isso, ter a oportunidade de poder discutir sobre o assunto é de extrema importância para a formação de um profissional completo (2). A única ressalva diz respeito à complexidade de alguns textos, pois muitas vezes percebi que não tinha conceitos básicos de psicanálise para compreender de forma mais ampla o conteúdo dos textos. Porém alguns foram muito "gostosos" de ler, como por exemplo, o texto sobre adoção. No geral, o curso é muito válido e com certeza, deve continuar, pois de outra maneira, ficaremos defasados em relação a um aspecto fundamental em nossas carreiras. Gostaria também de agradecer à Raquel por sempre ouvir meus "causos" e me ajudar a compreender melhor muitas atitudes e a enxergar a situação de um outro enfoque(3).

1 idéia: O curso apresenta uma proposta são aprofundados durante a graduação e a residência.

$2^{a}$ idéia: O curso contribui para ampliar a visão da Pediatria, identificar e atuar sobre os aspectos psíquicos do pacientes e para buscar algo além do orgânico.

$3^{a}$ idéia: Pude desabafar, fui acolhida e compreendida.

$1^{a}$ idéia: O curso apresenta uma proposta sobre 58 - A integração da Psicologia com o temas de extrema relevância que não são aprendizado na Pediatria é muito importante e aprofundados durante a graduação e a necessário. Podemos comentar sobre vários residência.

assuntos que nem sempre são lembrados ou $2^{\text {a }}$ idéia: Poderia se introduzir outras dinâmicas discutidos no nosso dia-a-dia (1). A idéia de para tornar as discussões mais interessantes. lermos textos para nos embasar para as 
discussões é muito boa, porém, às vezes, ficamos muito presos ao seu seguimento e perdemos a possibilidade ou espaço para relatarmos acontecimentos pessoais. Sugiro que pudéssemos ler não só textos científicos, como também reportagens ou quaisquer outros documentos(2). 